Policy Research Working Paper 2966

\title{
Health and Poverty in Guatemala
}

\author{
Michele Gragnolati \\ Alessandra Marini
}

The World Bank

Latin America and the Caribbean Region

Human Development Sector Unit

January 2003 


\begin{abstract}
Unlike many other countries in Latin America, Guatemala is only at the beginning of the demographic and epidemiological transition. The population is young, is growing rapidly, and is still primarily rural. Guatemala is among the worst performers in terms of health outcomes in Latin America, with one of the highest infant mortality rates and one of the lowest life expectancies at birth. Major causes of death in Guatemala still include treatable and communicable diseases, such as diarrhea, pneumonia, cholera, malnutrition, and tuberculosis. A significant share of Guatemalans lack access to health care services. A combination of both supply- and demand-side constraints limit the ability of households to seek health care services in Guatemala, with supply-side constraints
\end{abstract}

playing a more dominant role in rural areas than urban. Some progress has been made in reforming the health sector. Important steps have been taken on the institutional side, with health being one of the pilot ministries to decentralize financial management under the Integrated System for Health Care (SIAS program). Public spending has shifted toward preventive care, which is essential for treatıng the health problems faced by the poor. Despite these efforts, spending and health outcomes has not improved significantly. In addition, public spending on health is not well targeted. Overall public health spending benefits the highest quintiles disproportionately. By type of facility, public spending on hospitals is by far the most regressive.

This paper-a product of the Human Development Sector Unit, Latin America and the Carıbbean Region-is part of a larger effort in the region to study poverty and human development processes. Copies of the paper are avalable free from the World Bank, 1818 H Street NW, Washington, DC 20433. Please contact Michele Gragnolati, room MC11-234, telephone 202-458-5287, fax 202-522-2955, email address mgragnolatı@worldbank.org. Policy Research Working Papers are also posted on the Web at http://econ.worldbank.org. Alessandra Marini may be contacted at amarini@worldbank.org. January 2003. (65 pages)

The Policy Research Working Paper Senes disseminates the findings of work in progress to encourage the exchange of ideas about development issues. An objective of the series is to get the findings out quickly, even if the presentations are less than fully polished. The papers carry the names of the authors and should be cited accordingly. The findings, interpretations, and conclusions expressed in this paper are entirely those of the authors. They do not necessarly represent the view of the World Bank, its Executive Directors, or the countries they represent. 


\section{Health and Poverty in Guatemala}

\section{Michele Gragnolati and Alessandra Marini World Bank}

The authors would like to thank Kathy Lindert (Task Manager of the Guatemala Poverty Assessment) for exceptional direction and for important comments and insights. Additional helpful comments and insights were received by: Harold Alderman (World Bank), Caridad Araujo (U.C. Berkeley), Chris Barrett (Cornell University), Carlos Becerra (INE), Giuliano Caloia (World Bank), Carlos Cifuentes (INE), Joanne Csete (Human Rights Watch), Heidi Deman (INCAP), Hilda Fanny (INCAP), Maggie Fisher (INCAP), Vivien Foster (World Bank), Ana Maria Ibanez (World Bank), Jerry La Forgia (World Bank), Judy McGuire (World Bank), Adam Montes (INCAP), Patricia Reynoso (World Bank), David Sahn (Cornell University), Carlos Sobrado (World Bank), Eduardo Somensatto (World Bank), Diane Steele (World Bank), Emil Tesliuc (World Bank), Maurizia Tovo (World Bank), Renos Vakis (World Bank). 



\section{Executive Summary}

The objective of this document is to provide up-to-date information on the characteristics and patterns of the health status of the Guatemalan population and recommend possible solutions to the institutional, financing, and implementation problems that exist within the health sector.

The Health Situation. Unlike many other countries in Latin America, Guatemala is only at the beginning of the demographic and epidemiological transition. The population is young, is growing rapidly, and is still primarily rural. Life expectancy in Guatemala (at 65 years) is the lowest in Central America, 12 years less than in Costa Rica. Infant mortality (45 per thousand) is the highest in Central America. Guatemala has the highest prevalence of chronically malnourished children in Latin America (44 percent). The prevalence of contraceptive use (27 percent) is the second lowest in Latin America. The total fertility rate (five children per woman) is the highest in Latin America. In December 2000, 4,000 cases of AIDS were officially recognized in Guatemala, with possible under-estımation [check] of 50 percent. Over time, the proportion of women infected by the virus has increased significantly, and the increase in infected women of reproductive age implies that there is also a higher probability of mother's transmitting the virus to their children. In addition, a closer look at demographic and health indicators reveals the existence of large inequalities in health performance across geographic areas and soc1oeconomic groups. The poor, people who live in rural areas, and the indigenous population have worse health outcomes than do the non-poor, people who live in urban areas, and the nonindigenous population. While not complete in terms of coverage of health outcomes issues, the Guatemalan Living Standard Measurement Survey (ENCOVI) is unique in terms of its representative sample and its data on other themes (as it is a multi-topic survey) and on poverty variables.

The Health Supply. As in most of Latin American countries, the major actors in Guatemala's health sector are the Ministry of Public Health and Social Assistance (MPSAS), the Guatemalan Social Security Institute (IGSS), the private for-profit sector, and private voluntary organizations. Netther the public nor the private sector is providing adequate health services to the population, which has limited contact with both the public and private delivery system. Overall, only 11 percent of the Guatemalan population have access to health services, based on the World Health Organization's definition of distance to a health facility measured in terms of traveling time.

The Integrated System for Health Care (Sistema Integrado Atencion de Salud) or SIAS, which the government introduced in 1997, aims to extend basic services to impoverished indigenous populations who live in rural hamlets with little or no access to health services. The SIAS does this by contracting NGOs both to provide and administer health care services. Preliminary evidence indicates that immunization coverage rates have increased since the introduction of SIAS, as has the monitoring of normal pregnancies by medically trained health specialists.

The combination of poor health indicators and low rates of utilization of public health facilities suggest that the type, quantity, and quality of the services being provided by the government do not match what is needed to improve health indicators or what is demanded by the public. Three demographic features of the population further complicate the process of increasing access to and the quality of health services. First, a large percentage of the population is indigenous (43 percent) belonging to more than twenty different Mayan language groups. The indigenous population, which has traditionally had the worst socioeconomic indicators, tends to live in remote rural areas, to lack access to public services, and to experience discrimination. Second, a large number of workers migrate during the year from the western highlands to southern 
plantations with a detrimental effect on their health. In general, the migrants have no (or limited) access to health services. The precarious conditions of life (in particular, workers' inadequate houses, which often lack basic services) and of work (such as exposure to pesticides and unsafe machinery) favor the transmission of diseases and increase the risk of accidents. Malnutrition, respiratory and gastrointestinal infections, and on-the-job accidents are among the most important risks to the health of migrants. In addition, the high incidence of prostitution in the fincas, especially in the area of Escuintila, increases the risk of contracting sexually transmitted diseases and AIDS. Alcoholism is also an important cause of morbidity for the migrant population. Third, several thousand people have been displaced as a result of internal strife. The majority of those who returned to Guatemala resettled in the most remote areas, where they are now living in precarious conditions with limited access to basic services.

The Demand for Health Care. Public health facilities tend to be underutilized. If they can afford it, Guatemalan people prefer to use private facilities that provide health care services. Only the poor, people who live in rural areas, and the indigenous population use public health facilities more often than private facilities. The proportion of individuals who are treated by doctors varies significantly by consumption quintiles (from 14 percent of the poorest to almost 60 percent of the richest). Poor and extremely poor individuals often rely on assistance from other members of the household or on self-medication.

The type and quality of prenatal care and assistance during birth are very important factors for the health of mothers and their children and are, therefore, important elements in evaluating the health conditions of a given country. Almost 80 percent of women with children surveyed by ENCOVI had a prenatal visit in Guatemala, a proportion that reaches almost 90 percent for women in the highest consumption quintile and falls to 66 percent for women in the lowest consumption quintile. More than a quarter of women in rural areas had no prenatal check. The corresponding figure is more than halved in urban areas (13 percent). There is also an important difference among different socioeconomic groups in the type of personnel who provide assistance during pregnancy. . Almost 90 percent of the richest women receive assistance from doctors, while the corresponding figure is only 20 percent for the poorest women who, in the majority of the cases, are assisted by midwives. Twice as many women in urban areas as in rural areas are visited by a doctor ( 78 percent versus 35 percent). The same pattern prevails between nonindigenous and indigenous women.

Health Financing. In the late 1990 s, Guatemala had the second lowest per capita public spending on health in Latin America. The majority of public resources (about 80 percent) are allocated for current activities. The proportion of external financing is very low (14 percent of total) and is mostly in forms of grants. The distribution of public spending on health (net of cost recovery from the patients) is skewed towards people in the higher quintiles, who benefit most from costly visits in public hospitals located in urban areas. Richer people can devote more of their private resources to taking care of their health, a factor that helps to explain the inequality observed across socioeconomic groups. People in the highest consumption quintile spend, on average, 30 times more than people in the poorest quintile spend on their health.

Recommendations. Guatemala's poor health indicators are due, in part, to problems that are outside of the control of public health authorities and not likely to be solved in the short run. These problems include: (i) widespread poverty due to limited household resource availability; (ii) poor environmental conditions; (iii) the limited availability of private sector providers of an adequate quality; and (iv) a general lack of knowledge about the benefits of modern medicine, especially among the indigenous population. Changing these underlying factors will require 
effective economic programs to combat poverty (focused mostly on those rural areas with a large indigenous population) and expanded educational investments.

Nevertheless, there are some actions that the government can and should take in the short- and medium-turn to improve health indicators and reduce inequality among areas and socioeconomic groups.

The relative youth of the Guatemalan population means that, for the foreseeable future, the major problems confronting the health sector will be those of the young instead of the old. The widespread poverty in the country means that the government's short-term priorities should be to combat the infectious and parasitic diseases associated with poverty, which are still more prevalent than non-communicable diseases. Increasing knowledge and access to effective family planning methods, especially in rural areas and among the poor and the indigenous population, would both reduce population growth and improve reproductive and child health indicators. Given the limited resources currently assigned to health, the government should ensure that the planned increase in resources to the health sector does indeed materialize. The program to extend coverage of basic health services should be evaluated carefully, and the program should either be scaled-up or redesigned depending on the results of that evaluation. The frequency of blood transfusion as a cause of AIDS infection makes it essential to reform the national system of blood control.

In the medium-term, the government should attempt to mobilize additional resources for health and should take additional steps to improve the efficiency and quality of services offered. Some ways to do this include: (i) introducing a system of referral and counter-referral; (ii) charging IGGS beneficiaries for services they receive in MSPAS facilities; (iii) allowing non-IGGS population to use IGGS facilities and charging the client, rather than MSPAS, for the use; and (iv) considering contracting out certain services within IGGS and MSPAS to private services (In addition to those contracted to NGOs to expand coverage of basic health care). As the population ages and the epidemiological transition progresses, more resources should be allocated to attempts to cure and prevent non-communicable and degenerative diseases.

In addition, two policy options are available to make public spending more progressive. The first is to move public resources away from hospitals towards community centers, health posts, and health centers (in other words, increasing the share of resources devoted to primary health care). The second is to introduce cost recovery mechanisms that charge different fees according to each user's income. The current policy of providing services free-of-charge in all type of public facilities benefits the rich more the poor, who tend to attend community centers, health posts, and health centers where visits cost less in terms of both time and money. Increasing resources devoted to the health sector is a key recommendation because, in this way, more can be spent on preventive and primary care to improve basic services without having to reduce the absolute amount of resources available to hospitals. 


\section{Introduction}

This paper was prepared as background for the World Bank's Poverty Assessment for Guatemala. The objective of the paper is to provide a detailed analysis of the health sector in Guatemala, with special emphases on the health conditions of the poor and on distribution and inequality issues. The study also provides recommendations to the government in Guatemala on how to improve the efficiency, quality, and equity of health services in the community.

The findings presented in this report are based on the Guatemalan Living Standard Measurement Survey (ENCOVI 2000/INE), a nationally representative, multipurpose household survey carried out durng the period July to December 2000. ENCOVI 2000 data are available for 7,276 households (37,771 individuals) living in urban and rural areas of 22 departments in eight regions all over the country. While not complete in terms of its coverage of health issues, the ENCOVI is unique in terms of its representative sample and its data on other themes and poverty variables.

Guatemala is a very diverse country-demographically, geographically, ethnically, economically, and socially. The total population of Guatemala in 1999 was approximately 11 million people, implying an average density of 96 people per square kilometer. Elevations range from sea level to about 3,800 meters. Despite the fact that one-fifth of the population lives in Guatemala City and that Guatemala has had a relatively high rate of population growth (2.6 percent between 1994 and 1999), Guatemala is the least urbanized country in Central America; only 39 percent of the people live in urban areas. While Guatemala is the most populous country and the largest economy in Central America, its rural and Mayan population still lives in great deprivation and are excluded socially, economically, and politically due to language and geographical barriers and to a lack of education and economic opportunities.

Compared with other countries with a similar per capita GDP level, Guatemala stands out as having an inordinately high rate of poverty. According to the most recent estimates, 56 percent of Guatemalan families lived below the poverty line in 2000 , which is defined as having insufficient resources to purchase a basic basket of goods and services. Moreover, 16 percent were in extreme poverty, in other words, they could not afford a basic basket simply of food. These two figures are even higher for the indigenous sub-population: 76 percent and 27 percent respectively. ${ }^{1}$

Guatemala has among the worst health outcomes in all of Latin America, as shown in Part I. Although it is tempting to ascribe this poor performance to poverty and prolonged civil strife, these are only part of the problem. Key obstacles to better outcomes include inadequacies and inefficiencies on the supply side, as shown in Part II as well as a number of factors on the demand side (Part III). Building on this analysis, we present a set of recommendations for ways in which the government could better invest public resources to ease these constraints and to promote better outcomes for its population, as discussed in Part IV.

\footnotetext{
${ }^{1}$ World Bank estimates based on ENCOVI 2000/INE
} 


\section{I: Health Challenges in Guatemala}

Guatemala is clearly lagging behind in the demographic and epıdemiological transitions and has among the worst health indicators in Latin America, even worse than those of its Central American neighbors.

\section{The Demographic Transition}

The1994 Census estimated the population of Guatemala to be of $8,331,874$ inhabitants, with a population density of 77 inhabitants per squared kilometer. According to the projections of the National Statistical Office (INE), the population reached 11 million individuals in 1999, as a result of average yearly increases of 2.6 percent.

As shown in Table 1.1, the general mortality rate decelerated significantly over the last few years of the 1990s in line with the ageing trend of the world population. At the same time, the number of live births increased by about 2 percent in the 1995-99 period as a consequence of past high fertility that means that a large share of the population are currently in their reproductive years. As a result of the reduction in mortality rate (especially at younger ages ${ }^{2}$ ), life expectancy at birth has increased from 57 years in 1980 to 65 years in $1999 .^{3}$

Table 1.1: Demographic Indicators in Guatemala: Historical Trend

\begin{tabular}{l|cccc}
\hline & 1995 & 1997 & 1998 & 1999 \\
\hline Total Population (thousands of people) & 9,976 & 10,456 & 10,791 & 11,111 \\
Number of Live Births (thousands of people) & 372 & 370 & 378 & 378 \\
Birth Rate (number of births per 1,000 inhabitants) & 44.6 & 35.4 & 35.1 & 34.0 \\
General Mortality (number of deaths per 1,000 inhabitants) & 7.7 & 5.5 & 5.3 & 4.8 \\
\hline
\end{tabular}

Source. Situacion de Salud en Guatemala, Indicadores Basicos (1995, 1997, 1998, 1999)

Guatemala's Extremely Young Population. Given the high fertility observed in the past, the profile of population in Guatemala is still very young, as shown in Figure 1.1. For example, young people under the age of 15 account for 44 percent of the total population. The corresponding figure for individuals older than 65 is only 4 percent.

\footnotetext{
${ }^{2}$ See Part III for more detailed information on the morbidity pattern of the last few years.

${ }^{3}$ HNP Statıstıcs, World Bank.
} 
Total Population

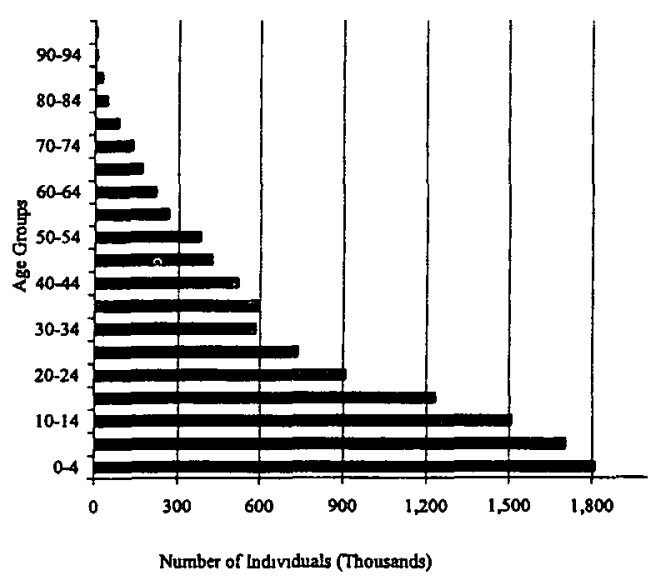

Poor/Non Poor

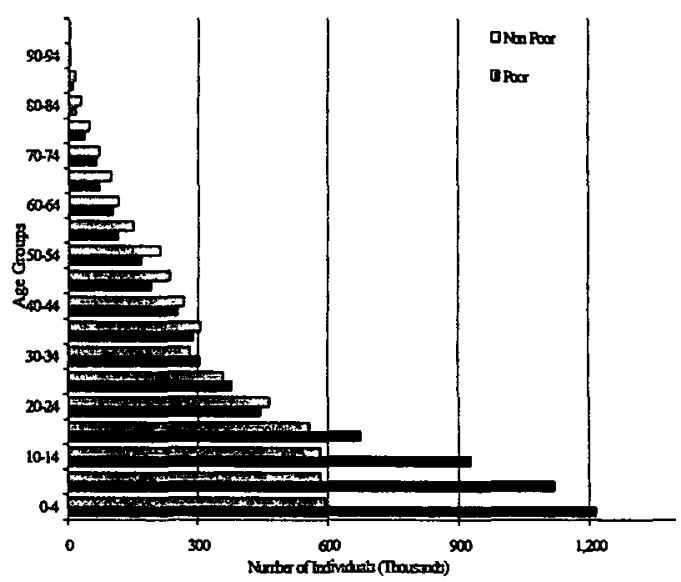

Source World Bank calculations using the ENCOVI 2000, Instituto Nacional de Estadistica - Guatemala

The median age for the Guatemalan population in 2000 was only 18.0 years compared to 24.4 years, which is the average for the Latin America and Caribbean region.

Table 1.2: Median Age in Guatemala and the World, 2000

\begin{tabular}{l|c}
\hline \multicolumn{2}{|c|}{ Median Age (years) } \\
\hline Guatemala & 18.0 \\
World Total & 26.5 \\
Africa & 18.4 \\
Asia & 26.2 \\
Europe & 37.3 \\
Northern America & 35.6 \\
Latin America \& Caribbean & 24.4 \\
Oceania & 30.9 \\
\hline Source: World Bank calculations using the ENCOVT 2000, Instituto Nacional de Estadistica - Guatemala for \\
Guatemala, United Nations (200I) for the rest of the world.
\end{tabular}

The dependency ratio, measured as the ratio of individuals younger than 15 and older than 65 compared to all individuals in the 15 to 64 age group, is 0.9 . Children still account for the largest percentage of all dependents; more than nine in every 10 people in the dependent population in Guatemala are under the age of $15 .^{4}$ Despite a slight reduction over the last 10 years, the dependency ratio in Guatemala is the highest in the Latin American region and is comparable only to those observed in African countries. Note the similar patterns high dependency ratios observed in the other Central American countries (Honduras, Nicaragua, Panama, and El Salvador).

\footnotetext{
${ }^{4}$ Authors' elaboration of the ENCOVI/INE 2000 data.
} 
Table 1.3: Dependency Ratios - Latin America and the Caribbean Region

\begin{tabular}{l|cc}
\hline \multicolumn{2}{l}{ Dependents as Proportion of Working- } & Age Population \\
\hline 1980 & 1999 \\
\hline Guatemala & 1.0 & 0.9 \\
Bolivia & 0.9 & 0.8 \\
Hait & 0.9 & 0.8 \\
Honduras & 1.0 & 0.8 \\
Nicaragua & 1.0 & 0.8 \\
Paraguay & 0.9 & 0.8 \\
El Salvador & 0.9 & 0.7 \\
Chile & 0.6 & 0.6 \\
Colombia & 0.8 & 0.6 \\
Dominican Republic & 0.8 & 0.6 \\
Ecuador & 0.9 & 0.6 \\
Mexico & 1.0 & 0.6 \\
Panama & 0.8 & 0.6 \\
Peru & 0.8 & 0.6 \\
Costa Rica & 0.7 & 0.6 \\
Brazil & 0.7 & 0.5 \\
Bulgaria & 0.5 & 0.5 \\
Puerto Rico & 0.7 & 0.5 \\
Trunidad and Tobago & 0.7 & 0.5 \\
LAC & 0.8 & 0.6 \\
Low \& middle income & $\mathbf{0 . 8}$ & $\mathbf{0 . 6}$ \\
World & $\mathbf{0 . 7}$ & $\mathbf{0 . 6}$ \\
\hline
\end{tabular}

Source $\cdot W D I$

Fertility remains the driving force behind the natural increase of the population. As shown in Table 1.4, Guatemala had a total fertility rate of 5.0 in 1998, practically unchanged from 1995 and well above the replacement level of 2.1 children per woman. ${ }^{5}$ It is the highest fertility rate of all of the Latin America and the Caribbean countries and is comparable to those observed in the least developed countries in the world. According to the latest UN report, Africa had a total fertility rate of 5.3 children per woman, compared to only 2.7 in the Latin American region and 2.8 in the world as a whole during the $1995-2000$ period. $^{6}$

Table 1.4: Total Fertility Rate - Guatemala and Latin America

\begin{tabular}{l|l}
\hline Guatemala 1998/99 & 5.0 \\
Guatemala 1995 & 5.1 \\
Bolivia 1998 & 4.2 \\
Nicaragua 1997 & 3.6 \\
Peru 1996 & 3.5 \\
Dominican Republic 1996 & 3.2 \\
Colombia 1995 & 3.0 \\
Brazil 1996 & 2.5 \\
\hline
\end{tabular}

Note. Women $15-49$

Source DHS

\footnotetext{
${ }^{5}$ The replacement level is the fertility level that needs to be sustained over the long run to ensure that a population replaces itself (children born replace people who have died).

${ }^{6}$ UN, 2001
} 
Guatemala has one of the lowest rates of contraceptive use in Latin America, second only to Hait $^{10}$ (see Table 1.6). Note that contraceptive use in general is very low in Latin America. A recent survey presented by the Scientific Committee of Health and Women showed that about half of the pregnancies in Latin America (52 percent) are unwanted and they happen, in part, because many adolescents do not use the available contraceptive methods. ${ }^{11}$

Table 1.6: Contraceptive Use in Guatemala and Latin America

\begin{tabular}{l|cc}
\hline & \multicolumn{2}{|c}{ Use of Contraceptive Methods } \\
& Any method & Any modern method \\
\hline Guatemala 1998/99 & $\mathbf{2 6 . 6}$ & $\mathbf{2 1 . 7}$ \\
Guatemala 1995 & $\mathbf{2 1 . 4}$ & $\mathbf{1 8 . 4}$ \\
Guatemala 1987 & $\mathbf{1 6 . 2}$ & $\mathbf{1 3 . 4}$ \\
Haiti 1994/95 & 12.3 & 8.9 \\
Bolivia 1998 & 31.4 & 16.5 \\
Ecuador 1987 & 29.0 & 23.5 \\
Paraguay 1990 & 32.7 & 23.6 \\
Peru 1996 & 40.9 & 26.4 \\
Mexico 1987 & 33.9 & 28.9 \\
El Salvador 1985 & 32.3 & 30.4 \\
Trinidad \& Tobago 1987 & 37.4 & 31.5 \\
Nicaragua 1997 & 40.8 & 39.0 \\
Colombia 1995 & 48.1 & 39.5 \\
Dominican Republic 1996 & 44.6 & 41.3 \\
Brazil 1996 & 55.4 & 51.0 \\
\hline Sour DHS &
\end{tabular}

Source DHS

In addition, Guatemala comes second lowest in Latın America on the basis of the average age of mothers at the time of their first birth (Table 1.7). There is considerable evidence that childbearing both at very young and at relatively old ages has deleterious consequences for the health and survival of those babies. . In Guatemala, the prevalence of chronic malnutrition among children whose mothers were younger than 18 years old at the time of giving birth is much higher than that of children of older mothers ( 51 percent and 45 percent respectively). ${ }^{12}$

\footnotetext{
${ }^{10}$ Because of the high number of missing observations, the ENCOVIINE data do not allow for an analysis of the actual use of contraceptive methods. The data in the table refer to DHS data from various years.

"A total of 7,456 women aged between 15 and 45 years from 14 Latin countries including Brazll participated in the research. The research revealed also that the younger the woman, the lower the use of contraceptives Among adolescents aged 15 to 19 years, 71 percent did not use any method to prevent pregnancy. Despite those rates, 98 percent of those interviewed admitted to knowing about contraceptive pills but only 28 percent of them use it. (Gazeta do Povo-PR, capa-classificados, 11/13)

${ }^{12}$ Marinı and Gragnolati (2001)
} 
Table 1.7: Age of Mother at First Birth - Guatemala and Latin America

\begin{tabular}{l|l}
\hline Guatemala 1998/99 & 20.3 \\
Nicaragua 1997 & 19.7 \\
Dominican Republic 1996 & 21.1 \\
Bolivia 1998 & 21.5 \\
Peru 1996 & 21.5 \\
Colombia 1995 & 22.1 \\
Brazil 1996 & 22.4
\end{tabular}

Source DHS

In Guatemala, women in the poorest consumption quintile, who have the most limited knowledge of birth control methods, have on average nine pregnancies compared with four for women in the top consumption quintile. Note that the average number of pregnancies among non-indigenous women (five) is the same as among non-poor women. Indigenous women have on average a lower number of pregnancies than poor (eight) and extremely poor women (nine). Peten is the region with the highest average number of pregnancies (almost eight per woman). In the Metropolitan region, women have on average only four pregnancies (Table 1.8).

\section{Table 1.8: Average Number of Pregnancies in Guatemala - Women aged 40-44}

\begin{tabular}{l|l}
\hline Total & 6.0 \\
Quintile & \\
Poorest & 8.5 \\
Fourth & 8.0 \\
Second & 7.0 \\
Middle & 5.4 \\
Richest & 3.6 \\
Poverty Status & \\
Non Poor & 4.5 \\
All Poor & 7.8 \\
Extremely Poor & 8.5 \\
Ethnicity & \\
Indigenous & 7.1 \\
K'iche & 6.6 \\
Q'ueqchi & 8.1 \\
Kaqchiquel & 6.4 \\
Mam & 7.8 \\
Other Mayan & 7.3 \\
Other Indigenous & 3.7 \\
Non-indigenous & 5.3 \\
Region & \\
Peten & 7.8 \\
Norte & 7.5 \\
Noroccidente & 7.0 \\
Suroriental & 6.8 \\
Suroccidente & 6.7 \\
Nororiental & 6.0 \\
Central & 5.8 \\
Metropolitana & 4.3 \\
\hline Source. World Bank & \\
\hline
\end{tabular}

Source. World Bank calculations using the ENCOVI 2000, Instituto Nacional de Estadistica - Guatemala 
Traditional and religious values together with lack of education and information on birth control technology are the most significant obstacles to the implementation of an efficient birth control policy in Guatemala. Campaigns aimed at changing people's preferences regarding education, health care, and the employment and social status of women could generate a significant reduction in fertility. Family planning would have more chance of success if it were incorporated into existing health services and were directed to very young people before they become sexually active.

The Indigenous Population. One very distinctive feature of Guatemalan demography, in comparison to other Latin American countries, is the large proportion of indigenous people in the population-: 43 percent according to the ENCOVI 2000/INE estimates. ${ }^{13}$ The population is divided into 24 ethnic groups, 23 of which are indigenous. There are three major indigenous groups: (i) the Mayan, characterized by 21 different ethnic groups; (ii) the Garifuna, originally from the first African contingencies that reached Guatemala during the colonial period; and (iii) the Xinca, whose origin is still unclear but who are believed to have been in the country since the Spanish arrived.

The four main indigenous languages include the Quiche (spoken by 22 percent of the indigenous population), the Kaqchiqel (21 percent), the Mam (20 percent), and the Q'eqchi (15 percent). The first three languages are each spoken by more than a million people.

Table 1.9: Most Common Indigenous Languages in Guatemala

\begin{tabular}{lcc}
\hline Language & $\begin{array}{c}\text { Number of Municipalities } \\
\text { where the Language is Spoken }\end{array}$ & $\begin{array}{c}\text { Number of Departments where } \\
\text { the Language is Spoken }\end{array}$ \\
\hline K'iche & 70 & 7 \\
Mam & 56 & 4 \\
Kaqchikel & 47 & 8 \\
K'eqchi & 15 & 4 \\
\hline
\end{tabular}

Source. OPS/OMS (200I)

Even if many people are bilingual (speaking both Maya and Spanish), a large number of people only speak one of the 23 non-official languages (including the 21 Mayan, Garifuna, and Xinca languages). These people can only communicate with other members of their ethnic community and, therefore, often are excluded and discriminated against by society in general. ${ }^{14}$

Indigenous people have maintained a separate Mayan cultural identity. The non-indigenous, regardless of their ethnic origin, speak Spanish, wear western clothes, and perceive themselves to be part of the dominant Western culture. ${ }^{15}$ While the non-indigenous belong to all social classes, the great majority of the indigenous population is concentrated at the bottom of the income distribution. According to the ENCOVI 2000/INE data, 76 percent of indigenous people are poor and 27 percent are extremely poor. Moreover, 49 percent of the indigenous population is illiterate, in contrast with 20 percent of the non-indigenous people. ${ }^{16}$

\footnotetext{
${ }^{13}$ Other estimates put the indigenous population share as high as 60 percent (CELADE, 1994)

${ }_{14}^{14}$ Clert, Woolcock, Ibañez, and Lindert (2001).

is The term ladino refers to a "person no longer identified culturally as Indian and, in Guatemala, includes many individuals genetically Indian as well as those representing various degrees of European-Indian racial mixtures who are Mestizos in the customary sense", Scrimshaw and Tejada (1970)

${ }^{16}$ Aged 14 and over, see Edwards J. (2001).
} 
The modernization process, the language barrier, the lack of policies that favor the indigenous population, and development programs that do not take into account indigenous customs and practices are all contributing to the social marginalization of indigenous people.

Internal Displacement. In 1987, the government introduced a process of voluntary individual repatriation for Guatemalans who had been living for years in the neighboring countries (mainly Mexico) to escape the conflict at home. Since then, an increasing number of Guatemalans have been returning home. It is estimated that about 20,000 returned between 1993 and 1995. Since 1996, when the Peace Accords where signed, many more people have returned. The majority of those who went back to Guatemala re-settled in the most remote areas, where they are now living in precarious conditions with limited access to basic services.

Internal migration ${ }^{17}$ is a long-term phenomenon in Guatemala. It originated during the colonial period when indigenous workers descended from the Altiplano to the south coast to work in activities related to business and to the salt trade. By the end of 1800 and with the coming of the liberal revolution, the land property system was modified and during the $1880 \mathrm{~s}$, a new capitalist system was formed, which depended on agricultural exports (initially coffee and then sugar and cotton). The lack of a workforce was overcome by forcing indigenous people to migrate from the mountains to the plantations on the southern coast. By the end of the $19^{\text {th }}$ century, representatives of the fincas (centers of agricultural production) began to contact people who were still living in the mountains (campesinos) and pay them in advance in return for a commitment to work for a fixed number of days on the finca in the future. This system of recruiting people contributed to the expansion of Guatemala's export economy. These recruiters (known as habilitadores) were normally people from good social and economic backgrounds, who were able to force those campesinos with debts or who were in need of money to migrate to the plantations.

According to the most recent ENCOVI 2000/INE estimates, there are about 150,000 temporary workers in the fincas of the Southern coasts, a third of whom are children. The majority of migrants come from rural areas characterized by smallholdings that do not produce enough foodto enable households to be self-sufficient. Therefore, household members migrate to the coast in order to get temporary jobs during the harvesting season for sugar, coffee, and cotton that enables them to increase their income. Migrants to the fincas are mainly indigenous workers, with high illiteracy rates.

Among the most important negative consequences of temporary migration are the disintegration of families (often only part of the family migrates), the loss of traditional values, and limited educational opportunities for migrants and their children. Migrants also have to bear many health costs. In general, they have no (or limited) access to health services. Also, the precarious conditions of life (in particular, workers' inadequate houses, which often lack basic services) and of work (such as exposure to pesticides and unsafe machinery) favor the transmission of diseases and increase the risk of accidents. Malnutrition, respiratory and gastrointestinal infections, and on-the-job accidents are among the most important risks to the health of migrants. In addition, the high incidence of prostitution in the fincas, especially in the area of Escuintila, increases the risk of contracting sexually transmitted diseases and AIDS. Alcoholism is also an important cause of morbidity for the migrant population.

Increasing migrants' access to basic health services is, therefore, a major challenge for Guatemala. Some progress has been made in that direction thanks to the implementation of the new Integrated Health Service (SIAS) - see Part II.

${ }^{17}$ MSPAS, IGSS, and OPS (1998). 


\section{Health Indicators}

Guatemala has among the worst health indicators in Latin America. Unlike many other countries in the region, Guatemala has yet to experience the epidemiological changes that are known as the health transition.

Infant Mortality. The infant mortality rate ${ }^{18}$ is considered to be one of the most sensitive measures of a population's health as it is usually a signal of the mortality risk from infectious, communicable diseases and other diseases associated with poor sanitary conditions and malnourishment. In Guatemala, infant mortality has declined steadily over the last two decades, reaching 45 deaths per 1,000 live births in 1998 (Table 1.10).

Table 1.10: Infant Mortality Rate in Guatemala - Historical Trend

\begin{tabular}{l|l}
\hline 1987 & 72.7 \\
1995 & 51.1 \\
$1998-99$ & 45.1 \\
\hline Source: $D H S$
\end{tabular}

However, compared to other countries in Latin America, infant mortality in Guatemala remains high (Table 1.11). Haiti, with 70 deaths per 1,000 live births, and Bolivia, with 50 , are the only countries that have higher mortality rates.

\section{Table 1.11:Infant Mortality Rate in the Latin America Region (1999)}

\begin{tabular}{ll}
\hline Haití & 70 \\
Bolivia & 59 \\
Guatemala & 40 \\
Dominican Republic & 39 \\
Peru & 39 \\
Honduras & 34 \\
Nicaragua & 34 \\
Brazil & 32 \\
El Salvador & 30 \\
México & 29 \\
Ecuador & 28 \\
Paraguay & 24 \\
Colombia & 23 \\
Panama & 20 \\
Trinidad \& Tobago & 16 \\
Costa Rica & 12 \\
Puerto Rico & 10 \\
Chile & 10 \\
LAC & 30 \\
Low \& middle income & 59 \\
World & 54 \\
\hline
\end{tabular}

Source: WDI 2001

Note: The WDI estımate of infant mortality rate for Guatemala differs from the DHS estımate in Table 1.10

\footnotetext{
${ }^{18}$ Annual number of deaths of children under the age of 1 per 1,000 live births.
} 
Life Expectancy. Life expectancy at birth $^{19}$ in Guatemala is one of the lowest in the Latin American region at 65 years, after only Haiti (53) and Bolivia (62 years) (see Table 1.12). Guatemala's life expectancy is lower than the 70 year target set by Pan American Health Organization for the end of the $20^{\text {th }}$ century in its report "Strategy for Health for All by the Year 2000."

Table 1.12: - Life Expectancy at Birth in the Latin America Region (1999) - Years

\begin{tabular}{lccc}
\hline & Male & Female & Total \\
\hline Haití & 51 & 56 & 53 \\
Bolivia & 60 & 64 & 62 \\
Guatemala & 62 & 68 & 65 \\
Brazil & 63 & 71 & 67 \\
Ecuador & 68 & 71 & 69 \\
Nicaragua & 66 & 71 & 69 \\
Peru & 66 & 71 & 69 \\
Colombia & 67 & 74 & 70 \\
El Salvador & 67 & 72 & 70 \\
Honduras & 67 & 72 & 70 \\
Paraguay & 68 & 72 & 70 \\
Dominican Republic & 69 & 73 & 71 \\
México & 69 & 75 & 72 \\
Trinidad \& Tobago & 70 & 75 & 73 \\
Panama & 72 & 76 & 74 \\
Chile & 73 & 79 & 76 \\
Puerto Rico & 71 & 80 & 76 \\
Costa Rica & 75 & 79 & 77 \\
LAC & 67 & 73 & 70 \\
Low \& middle income & 63 & 66 & 64 \\
World & 65 & 69 & 66 \\
\hline
\end{tabular}

Source WDI 2001

Malnutrition. The epidemiological profile of Guatemala is characterized by a high prevalence of malnutrition ${ }^{20}$ and of infectious diseases associated with poverty (diarrhea and acute respiratory infections in particular), by the permanence of epidemics such as cholera and dengue, by an increase in chronic and degenerative non-communicable diseases (due to the aging of the Guatemalan population), and by a high incidence of deaths due to accidents and violence.

The prevalence of malnutrition is much higher in Guatemala than in its neighboring Central American countries or than in any other country in Latin America (Table 1.13). ${ }^{21,22}$

\footnotetext{
${ }^{19}$ The average number of additional years a person of given age could expect to live if current mortality trends were to continue for the rest of that person's life.

${ }^{20}$ Marni Gragnolati (2001).

${ }^{21}$ The selection of the countnes is based on available comparable data.

${ }^{22}$ Marini and Gragnolati (2001).
} 
Table 1.13: Prevalence of Malnutrition in the Latin America \& Caribbean

Countries

\begin{tabular}{l|ccc}
\hline Percentage of Children $<5$ & Stunted & Wasted & Underweight \\
\hline Guatemala 1987 & 57.8 & 1.3 & 33.2 \\
Guatemala 1995 & 49.7 & 3.3 & 26.6 \\
Guatemala 1998/99 & 46.4 & 2.5 & 24.2 \\
Guatemala 2000 & 44.2 & 2.8 & 22.3 \\
Bolivia 1998 & 26.8 & 1.3 & 7.6 \\
Peru 1996 & 25.8 & 1.1 & 7.8 \\
Nicaragua 1997 & 24.9 & 2.2 & 12.2 \\
Colombia 1995 & 15 & 1.4 & 8.4 \\
Dominican Republic 1996 & 10.7 & 1.2 & 5.9 \\
Brazil 1996 & 10.5 & 2.3 & 5.7 \\
\hline
\end{tabular}

Note Children $<5$

Sources. DHS and World Bank calculations using the ENCOVI 2000, Instituto Nacional de Estadistica - Guatemala.

The Main Causes of Morbidity and Mortality. Indicators of morbidity and mortality clearly reflect Guatemala's position in the epidemiological transition. Table 1.14 presents information on the main causes of mortality in Guatemala. ${ }^{23}$ Malnutrition is the most important cause of mortality, with almost 2 deaths per 1000 inhabitants in 1999. Deaths due to malnutrition have increased over time, which is the reverse of the trend observed for the two other most important causes of mortality-diarrhea or pneumonia. Deaths due to cholera seem to have decreased slightly. The data also indicate that there has been a recent decrease in the number of deaths due to suicide and accidents.

Table 1.14: The Main Causes of Mortality in Guatemala (1995-1999)

\begin{tabular}{lcccc}
\hline & 1995 & 1997 & 1998 & 1999 \\
\hline Diarrhea (per 1,000 inhabitants) & 0.65 & 0.36 & 0.48 & 0.29 \\
Pneumonia (per 1,000 inhabitants) & $\cdot$ & 1.14 & 1.12 & 1.08 \\
Pneumonia < 1 Year (per 1,000 kids < 1 year) &. & 13.77 & 13.73 & 11.31 \\
Cholera (per 1,000 inhabitants) & 0.10 &. & 0.10 & 0.09 \\
Malnutrition (per 1,000 inhabitants) & 0.45 & 0.12 & 1.54 & 1.73 \\
Tuberculosis (number of deaths) & $\cdot$ & 206 & 177 & 166 \\
Suicide (number of deaths) & $\cdot$ &. & 457 & 384 \\
Homicide (number of deaths) & $\cdot$ &. & 2376 & 1774 \\
Accidents (number of deaths) & &. & 3077 & 2741 \\
\hline
\end{tabular}

Source. Stuación de Salud en Guatemala, Indicadores Básicos (1995, 1997, 1998, 1999)

Table 1.15 presents the evolution of selected indicators of morbidity in Guatemala since 1995. While the incidence of cholera and dengue has rapidly decreased over the last five years, malaria, diarrhea, and acute respiratory infections have increased significantly. ${ }^{24}$

\footnotetext{
${ }^{23}$ The data come from a yearly publication of the Ministry of Health and Public Action of Guatemala, Situación de Salud en Guatemala, Indicadores Básicos.

${ }^{24}$ ENCOVUNE 2000 data indirectly confirm the finding that mortality from diarrhea and acute respiratory infections has decreased in the past few years. This seems to be due to increased use of modern medicines for treating infected cases. A very large proportion of children affected by diarrhea or acute respiratory infections are currently treated with medicines, regardless of their socioeconomic status or the area in which they live. Previous DHS surveys do not contain
} 
Table 1.15: Selected Indicators of Morbidity in Guatemala (1995-1999)

\begin{tabular}{lcccc}
\hline & 1995 & 1997 & 1998 & 1999 \\
\hline Incidence of Cholera (per 100,000 inhabitants) & 83.3 & - & 52.5 & 18.7 \\
Incidence of Diarrhea (per 10,000 inhabitants) & 83.8 & 100.3 & 249.3 & 347.1 \\
Incidence of Malaria (per 10,000 inhabitants) & 23.6 & 59.0 & 80.7 & 91.2 \\
Incidence of Dengue (per 10,000 inhabitants) & - & 5.91 & 4.25 & 3.26 \\
Incidence of ARI (per 10,000 inhabitants) & 178.8 & 536.1 & 539.5 & 917.3 \\
\hline
\end{tabular}

Source. Situación de Salud en Guatemala, Indicadores Básicos (1995, 1997, 1998, 1999)

Table 1.16 presents the estimated prevalence of diseases and accidents among the Guatemalan population in 2000 using the ENCOVI/INE 2000 survey. Overall, a quarter of the population reported having suffered from some type of accident or disease, however temporary (such as toothaches, headaches, or ear infections) during the month prior to the interview.

There is no significant difference in the prevalence of disease or accidents between people living in urban areas and those living in rural areas, nor between indigenous and non-indigenous individuals. The proportion of people who declared that they had been sick or to had had an accident increases with per capita consumption. Similarly, a higher prevalence of disease and accidents is observed among the non-poor than among the poor. This information is difficult to interpret because of the close correlation between income and reported morbidity. Poorer people may have higher opportunity costs to declaring themselves ill and staying at home or they simply may have a different perception of "being sick."

information on the prevalence of children treated with modern medicines but only on the oral re-hydration treatments, and, therefore, comparisons are not possible. See the next paragraph for a discussion of the prevalence and treatment of diarrhea and acute respiratory infections in Guatemala. 
Table 1.16: Prevalence of Diseases and Accidents Whole Population, \% of Cases

\begin{tabular}{l|l}
\hline Total & 24.8 \\
Consumption Quintile & 20.9 \\
Q1 & 22.0 \\
Q2 & 23.5 \\
Q3 & 25.5 \\
Q4 & 32.1 \\
Q5 & \\
Poverty Status & 28.4 \\
Non Poor & 22.0 \\
All Poor & 20.9 \\
Extremely Poor & \\
Ethnicity & 24.6 \\
Indigenous & 26.0 \\
K'iche & 33.2 \\
Q'ueqchi & 23.7 \\
Kaqchiquel & 22.3 \\
Mam & 19.6 \\
Other Mayan & 32.3 \\
Other Indigenous & 25.0 \\
Non-1ndigenous & \\
Area & 25.3 \\
Urban & 24.5 \\
Rural & \\
Region & 28.0 \\
Metropolitana & 28.4 \\
Norte & 29.7 \\
Nororiente & 23.2 \\
Suroriente & 23.7 \\
Central & 24.0 \\
Suroccidente & 19.1 \\
Noroccidente & 20.7 \\
Peten & \\
\hline
\end{tabular}

Note Data refer to the month before the interview

Source World Bank calculations using the ENCOVI 2000, Instituto Nacıonal de Estadística - Guatemala

Diarrhea and acute respiratory infections, together with under-nutrition, are the most important causes of child mortality in Latin America. Both the duration and the frequency of infectious diseases affect children's nutritional status by reducing their appetite and by interferng with their nutrient absorption, utlization, and requirement through a number of different mechanisms. These include loss of appetite, energy lost as heat during fever, loss of other nutrients in sweat, vomiting, decreased absorption of nutrients, and protein catabolism. ${ }^{25}$ On the other side, malnutrition makes children weaker and more vulnerable to infectious diseases such as diarrhea and respiratory infections.

Diarrhea diseases are the most important of all of the infant and child infections in developing countries in terms of their effect on the health status of infants and children. ${ }^{26}$ Diarrhea causes

${ }^{25}$ Rohde (1986); Victora et al (1986).

${ }^{26}$ Chen and Scrimshaw (1983) 
food to pass through the intestine too quickly to be absorbed. Epidemiological data indicate that diarrhea diseases occur with greater frequency during the period of weaning and that children's exposure to agents that cause diarrhea occurs largely through fecal contamination. ${ }^{27}$ The main cause of death from diarrhea is dehydration, resulting from the loss of fluids and electrolysis through the stools. ${ }^{28}$

The consequences of respiratory infections on children's growth are less clear. Martorell and Yarbrough (1983) found upper-tract respiratory infections to be negatively associated with children's speed of growth only in one of seven studies carried out in Africa and Latin America. A longitudinal study of 5,914 children conducted in Brazil between 1982 and 1986 revealed that, although severe respiratory infections had a negative impact on their growth, hospital admissions for children with diarrhea were more strongly associated with subsequent malnutrition than were admissions for pneumonia. At the same time, however, malnutrition was a more important risk factor for pneumonia than it was for diarrhea. All of the associations were stronger in the first two years of life than at older ages. ${ }^{29}$

Table 1.17 shows estimates of prevalence of and treatment patterns for diarrhea infections among children under six years old in Guatemala. Overall, 30 percent of the children suffered from diarrhea, a much higher proportion than that observed in the earlier 1998-99 DHS survey (12 percent). The data also show a significant difference in the prevalence of diarrhea between rural areas ( 35 percent) and urban ( 25 percent) areas and an increasing prevalence among children in the lower consumption quintiles. The Norte region had a much higher percentage of children suffering from diarrhea than any other region. Note that the same region had a very high prevalence of child chronic malnutrition (47 percent). ${ }^{30}$ The link between diarrhea and malnutrition is very strong and goes in both directions.

The majority of children who have diarrhea (68 percent) are treated with medicines, 12 percent with traditional remedies, and 7 percent with oral re-hydration salts. Only 4 percent of infected children did not receive any form of treatment. Children of richer households are more likely than children of poorer households to be treated with modern medicines instead of traditional remedies. A similar pattern is observed among the poor and the non-poor. There is no significant difference in treatment patterns between urban and rural areas. Non-indigenous people use oral re-hydration salts more frequently than indigenous people, while folk serum and folk remedies are more common among the indigenous. A very large proportion of children in the Peten and Metropolitan areas is treated with modern medicines. Modern medicines are used the least in the Norte region where there is a tendency to treat diarrhea with traditional remedies and simple water.

\footnotetext{
${ }^{27}$ Pebley, Hurtado and Goldman, (1996).

${ }^{28}$ PAHO, 1998

${ }^{29}$ Victora et al 1990

${ }^{30}$ Manni . and Gragnolati 2001.
} 
Table 1.17: Prevalence and Treatment of Diarrhea among Children under 6

\begin{tabular}{|c|c|c|c|c|c|c|c|c|c|}
\hline & \multirow{2}{*}{$\begin{array}{c}\text { Prevalence } \\
(\%)\end{array}$} & \multicolumn{8}{|c|}{ Treatment } \\
\hline & & Water & $\begin{array}{l}\text { Folk } \\
\text { Serum }\end{array}$ & $\begin{array}{c}\text { Oral Re- } \\
\text { Hydration } \\
\text { Salts } \\
\end{array}$ & $\begin{array}{l}\text { Herbal } \\
\text { Tea }\end{array}$ & $\begin{array}{c}\begin{array}{c}\text { Other } \\
\text { Folk } \\
\text { Remedies }\end{array} \\
\end{array}$ & $\begin{array}{l}\text { Modern } \\
\text { Medicines }\end{array}$ & Other & Nothing \\
\hline $\begin{array}{l}\text { Total } \\
\text { Consumption Quintile }\end{array}$ & 31.3 & 3.2 & 4.6 & 7.0 & 0.4 & 12.5 & 68.0 & 0.1 & 43 \\
\hline Q1 & 33.8 & 3.6 & 5.1 & 8.1 & 0.0 & 15.6 & 60.6 & 00 & 6.9 \\
\hline Q2 & 35.2 & 2.5 & 3.7 & 6.8 & 0.9 & 12.2 & 71.5 & 0.1 & 2.3 \\
\hline Q3 & 30.5 & 3.9 & 7.7 & 7.0 & 0.0 & 12.5 & 65.1 & 0.1 & 36 \\
\hline Q4 & 27.8 & 2.6 & 1.4 & 6.8 & 0.7 & 9.4 & 77.9 & 0.1 & 1.0 \\
\hline Q5 & 24.1 & 3.4 & 4.5 & 4.8 & 0.5 & 7.5 & 70.0 & 0.1 & 9.1 \\
\hline \multicolumn{10}{|l|}{ Poverty Status } \\
\hline Non Poor & 27.4 & 2.5 & 5.1 & 5.5 & 0.5 & 8.6 & 74.0 & 0.1 & 3.7 \\
\hline All Poor & 33.2 & 3.5 & 4.4 & 7.6 & 0.4 & 14.0 & 65.6 & 0.1 & 4.5 \\
\hline Extremely Poor & 33.8 & 4.4 & 5.8 & 8.1 & 0.0 & 16.8 & 57.8 & 0.1 & 7.1 \\
\hline \multicolumn{10}{|l|}{ Ethnicity } \\
\hline Indigenous & 35.6 & 3.6 & 5.6 & 6.6 & 0.5 & 13.7 & 64.5 & 0.2 & 5.5 \\
\hline K'iche & 30.5 & 6.2 & 1.7 & 4.4 & 0.1 & 21.9 & 61.5 & 0.1 & 3.4 \\
\hline Q'ueqchi & 49.7 & 1.6 & 1.7 & 10.3 & 0.5 & 6.8 & 66.0 & 0.6 & 12.5 \\
\hline Kaqchiquel & 32.9 & 1.4 & 9.3 & 5.7 & - & 8.1 & 71.7 & - & 3.9 \\
\hline Mam & 33.9 & 4.8 & 7.6 & 6.0 & 0.7 & 14.1 & 64.8 & - & 2.1 \\
\hline Other Mayan & 34.4 & 4.2 & 7.9 & 5.8 & - & 16.9 & 60.5 & - & 4.7 \\
\hline Other Indigenous & 43.4 & - & 12.0 & - & 15.1 & 42.9 & 30.0 & - & - \\
\hline Non-indigenous & 27.5 & 2.8 & 3.5 & 7.6 & 0.3 & 10.9 & 72.0 & 0.1 & 2.9 \\
\hline \multicolumn{10}{|l|}{ Area } \\
\hline Urban & 24.7 & 2.9 & 6.4 & 6.4 & 0.5 & 11.2 & 68.5 & 0.2 & 3.9 \\
\hline Rural & 34.5 & 3.3 & 4.0 & 7.3 & 0.4 & 12.8 & 67.8 & 0.0 & 44 \\
\hline \multicolumn{10}{|l|}{ Region } \\
\hline Metropolitana & 28.5 & 2.9 & 4.7 & 7.9 & 0.2 & 6.9 & 74.0 & 0.0 & 3.4 \\
\hline Norte & 50.7 & 6.5 & 5.2 & 9.9 & 0.4 & 8.7 & 58.0 & 0.6 & 10.6 \\
\hline Nororiente & -25.8 & 2.0 & 3.5 & 10.8 & 0.0 & 17.2 & 65.8 & 0.0 & 0.6 \\
\hline Suroriente & 254 & 0.0 & 4.7 & 13.0 & 0.9 & 16.0 & 63.8 & 0.3 & 1.4 \\
\hline Central & 26.3 & 1.7 & 4.5 & 4.8 & 0.3 & 15.5 & 67.2 & 0.0 & 6.1 \\
\hline Suroccidente & 32.9 & 2.6 & 4.7 & 5.1 & 0.5 & 12.2 & 72.8 & 0.0 & 22 \\
\hline Noroccidente & 28.7 & 5.0 & 4.8 & 5.2 & 0.3 & 18.4 & 61.7 & 0.0 & 4.7 \\
\hline Peten & 33.5 & 1.5 & 2.7 & 1.4 & 0.8 & 9.5 & 79.6 & 0.4 & 4.2 \\
\hline
\end{tabular}

Note: Data refer to the month before the interview

Source World Bank calculations using the ENCOVI 2000, Instituto Nacional de Estadística - Guatemala

Table 1.18 shows the prevalence of and treatment patterns for acute respiratory infections (ARD). Overall, mothers report that almost half of their children suffered from ARI in the month prior to the interview. No significant difference was observed in the prevalence of ARI among children of different economic status, poverty level, or ethnicity. ${ }^{31}$ The percentage of children suffering of respiratory infections is much higher in rural areas (51 percent) than in urban areas (41 percent). Norte and Nororiente regions had the highest prevalence.

\footnotetext{
${ }^{31}$ As for diarrhea, caution must be applied in using reported morbidity information to estimate the incidence of disease because of the close correlation between income and reported sickness observed in many household surveys
} 
Acute respiratory infection is a very common cause of illness among children in developing countries and is also one of the major causes of infant deaths in the world. There is growing evidence in the literature of a strong association between indoor air pollution and respiratory infections among preschool children. Studies in Guatemala also confirm the high exposure of women and children to toxic pollutants from fuel wood combustion. A recent study based on the 1998-99 DHS survey points to the strong association between acute respiratory infections and the use of fuel wood in homes without chimneys. ${ }^{32}$

A very high percentage of children suffering from respiratory infections are treated with medicines ( 84 percent), while folk remedies are used only in 7.5 percent of the cases. There is no significant difference in the type of remedies used by the poor and the non-poor. However, the extremely poor do seem to follow a different treatment pattern (medicines and natural remedies are used in 70 percent and 10 percent of the cases respectively). Similar to the pattern observed for diarrhea, a very high proportion of ARI infections among children in Peten is treated with modern medicines (93.9 percent). Natural medicines are used more often in the Norte and Nororiente regions, while folk remedies are used most often in the Nortoccidente region.

32 Torres (2001). 
Table 1.18: Prevalence and Treatment of Acute Respiratory Infections among Children under 6

\begin{tabular}{|c|c|c|c|c|c|}
\hline & \multirow{2}{*}{\begin{tabular}{|c|} 
Prevalence \\
$(\%)$
\end{tabular}} & \multicolumn{4}{|c|}{ Treatment } \\
\hline & & Modern Medicines & Natural Medicines & Folk Remedies & Nothing \\
\hline $\begin{array}{l}\text { Total } \\
\text { Consumption Quintile }\end{array}$ & 47.9 & 84.1 & 4.8 & 7.5 & 3.6 \\
\hline Q1 & 47.4 & 73.1 & 8.9 & 9.1 & 9.0 \\
\hline Q2 & 50.1 & 84.5 & 4.2 & 9.5 & 1.9 \\
\hline Q3 & 47.6 & 85.8 & 3.6 & 8.2 & 2.3 \\
\hline Q4 & 47.2 & 91.9 & 3.3 & 4.0 & 1.0 \\
\hline Q5 & 46.0 & 94.0 & 1.2 & 3.6 & 1.2 \\
\hline \multicolumn{6}{|l|}{ Poverty Status } \\
\hline Non Poor & 48.2 & 90.3 & 3.1 & 5.5 & 1.2 \\
\hline All Poor & 47.7 & 80.9 & 5.8 & 8.5 & 4.8 \\
\hline Extremely Poor & 47.6 & 71.1 & 10.1 & 8.8 & 9.9 \\
\hline \multicolumn{6}{|l|}{ Ethnicity } \\
\hline Indigenous & 48.8 & 78.7 & 6.0 & 9.4 & 5.8 \\
\hline K'iche & 41.2 & 83.7 & 5.1 & 9.3 & 1.9 \\
\hline Q'ueqchi & 58.5 & 80.5 & 1.5 & 2.5 & 15.5 \\
\hline Kaqchiquel & 50.8 & 73.7 & 5.7 & 14.1 & 6.5 \\
\hline Mam & 54.0 & 85.0 & 2.7 & 10.0 & 2.0 \\
\hline Other Mayan & 43.8 & 71.1 & 15.1 & 9.7 & 4.1 \\
\hline Other Indigenous & 33.7 & 70.8 & - & 29.2 & - \\
\hline Non-indigenous & 47.0 & 88.9 & 3.8 & 5.7 & 1.5 \\
\hline \multicolumn{6}{|l|}{ Area } \\
\hline Urban & 41.2 & 89.3 & 2.2 & 6.4 & 2.0 \\
\hline Rural & 51.1 & 81.9 & 5.9 & 7.9 & 4.2 \\
\hline \multicolumn{6}{|l|}{ Region } \\
\hline Metropolitana & 43.1 & 84.0 & 3.7 & 9.1 & 3.2 \\
\hline Norte & 63.6 & 73.9 & 10.7 & 4.3 & 11.1 \\
\hline Nororiente & 57.7 & 91.5 & 6.4 & 1.2 & 1.0 \\
\hline Suroriente & 49.1 & 88.3 & 1.4 & 9.0 & 1.4 \\
\hline Central & 46.5 & 84.1 & 4.7 & 6.7 & 4.5 \\
\hline Suroccidente & 49.2 & 84.9 & 4.8 & 8.7 & 1.7 \\
\hline Noroccidente & 36.6 & 79.5 & 2.9 & 12.7 & 4.6 \\
\hline Peten & 44.2 & 93.9 & 1.2 & 2.3 & 2.7 \\
\hline
\end{tabular}

Note Data refer to the month before the intervtew.

Source: World Bank calculations using the ENCOVI 2000, Instituto Nactonal de Estadistica - Guatemala

The first case of AIDS was reported in Guatemala in June 1984 in a 28-year old man coming from the United States. All of the cases registered during the following two years were related to homosexual men, who had lived in the United States and who came back to Guatemala when his disease was already in an advanced phase. ${ }^{33}$ In 1986 , for the first time, two women were found to have AIDS. They also came from the United States and had contracted the virus through a blood transfusion. In 1988, for the first time, two Guatemalan residents were reported to have

${ }^{33}$ Núñez (2001). 
contracted the virus-a 12-year-old girl who had received a blood transfusion and a 38-year-old homosexual man.

In December 2000, according to the National Program for AIDS control (Programa Nacional de Control de ETS y SIDA or PNS), 4,000 cases of AIDS were officially recognized in Guatemala, with a possible under-estimation of 50 percent. Over time, the proportion of women infected by the virus has increased significantly from a ratio of 6.5 infected men for each woman in 1986 to 3.0 infected men for each woman in 2000 . The increase in infected women of reproductive age implies that there is also a higher probability of vertical transmission from mothers to their children. In 1999, the number of children younger than 12 months old infected by the virus doubled over the previous year. Moreover, there has been a significant increase in the number of children that contracted the virus through blood transfusion or sexual abuse.

More than 50 percent of the reported cases are concentrated in the department of Guatemala, where, by the end of 2000 , the incidence peaked at 78 cases per 100,000 inhabitants.

The majority of cases are associated with the presence of sexual transmitted infections. The prevalence of such infections in Guatemala is probably associated, among other things, with very limited use of condoms and a lack of information on these infections and on how to prevent them.

"Women generally die during the delivery, either because they could not deliver or because they could deliver but then bleeded, had high temperature and died. It is their most common death." (IP, M2). ${ }^{34}$ Death associated with pregnancy or childbirth is one of the most important causes of mortality among women of reproductive age. According to the latest WHO and UNICEF estımates, the estimated number of maternal deaths in the world in 1995 was more than 500,000 , of which over one-half occurred in Africa, about 40 percent in Asia, and 4 percent in Latin America and the Caribbean. ${ }^{35}$ Among Central American countries, Guatemala clearly stands out as the country with the highest number of women who die from problems related to pregnancy or delivery (Table 1.19) Most of those deaths could be prevented by simple and cheap interventions. ${ }^{36}$ Among the most important determinants of maternal mortality are: large number of children, low maternal age at birth, spacing births close together, poor socioeconomic conditions, and limited access to health services. ${ }^{37}$

\section{Table 1.19:Maternal Mortality Rate - \\ Number of Women who Die during Pregnancy or Childbirth (per 100,000 live births)}

\begin{tabular}{lcc}
\hline & $\begin{array}{c}\text { Reported } \\
\text { most recently }\end{array}$ & $\begin{array}{c}\text { Adjusted } \\
\mathbf{1 9 9 5}\end{array}$ \\
\hline Guatemala & 190 & $\mathbf{2 7 0}$ \\
Nicaragua & 150 & 250 \\
El Salvador & 120 & 180 \\
Honduras & 110 & 220 \\
Panama & 70 & 100 \\
Costa Rica & 29 & 35 \\
\hline
\end{tabular}

\section{Source: WDI, 2001}

Note: "Maternal Mortality ratios shown in the table as reported are estimates based on national surveys, vital registration, or surveillance or are derived from community and hospital records. Those shown as adjusted are based on

\footnotetext{
${ }^{34}$ QPES (2001).

${ }^{35}$ WHO (2001).

${ }^{36}$ UNICEF (1999)

${ }^{37}$ DHS (1995).
} 
a modelıng exercise cartied out by the WHO and UNICEF. In this exercise maternal mortality was estımated with a regression model using information on fertility, birth attendants, and HIV prevalence. Netther set of ratios can be assumed to provide an accurate estimate of maternal mortality in any of the countries in the table". (WDI, 2001 page 109).

The Qualitative and Poverty Exclusion Study (QPES) indicates that maternal mortality is an important idiosyncratic shock faced by the villagers. ${ }^{38}$ In particular, a lack of health services and ambulances for transportation is the most important cause of death for women in one village in the survey. ${ }^{39}$

\section{Reasons for Guatemala's Poor Health Outcomes}

Guatemala's poor health performance is mainly due to poverty and to the country's prolonged history of civil conflict.

Poverty. Guatemala is the least urbanized country in Central America, with only 39 percent of the people living in urban areas. Compared to other countries, Guatemala stands out as having an inordinately high rate of poverty for its level of per capita GDP. According to the most recent estimates, 56 percent of Guatemalan families lived below the poverty line in 2000, which is defined as having insufficient income to purchase a basic basket of goods and services. Among these, 16 percent were in extreme poverty, which means that they could not afford a basic baske: simply of food. These two figures are higher for the indigenous sub-population-76 percent and 27 percent respectively. ${ }^{40}$

Indeed there is some correlation between poverty and poor health outcomes, as is evident in Table 1.20 where the region with the highest poverty rates also has the highest rate of child malnutrition.

Table 1.20: Poverty and Health Outcomes by Region

\begin{tabular}{lcc}
\hline Region & Prevalence of Child Malnutrition & Poverty Rate \\
\hline Suroccidente & 50.1 & 30.1 \\
Noroccidente & 60.6 & 18.8 \\
Norte & 47.0 & 12.1 \\
Suroriente & 41.4 & 10.7 \\
Central & 41.8 & 9.8 \\
Nororiente & 34.2 & 7.6 \\
Metropolitana & 30.0 & 6.9 \\
Peten & 36.9 & 4.0 \\
\hline Source World Bank calculations using the ENCOVI 2000, Instituto Nacional de Estadistica - Guatemala
\end{tabular}

\footnotetext{
${ }^{38}$ The QPES provides the main source of qualitative information for the GUAPA. The QPES collected data in ten rural communities that are also included in the ENCOVI. The configuration of these villages seeks to examine perceptions of poverty and exclusion for a number of ethnicitses; as such, the sample includes two villages from each of the following ethnic groups: Mam, K'iche, Q'eqchı, Kaqchıqel, and Ladino (non-indigenous). For the purposes of protecting the anonymity of respondents, each village is given a code name (e.g., M1, M2, K1, K2, etc). The field work covered a number of themes including: perceptions of poverty and welfare; perceptions of risk, shocks and vulnerability; social capital, user perceptions of public programs; community perceptions of education; and gender roles and issues. The main research instruments included: community focus groups, direct interviews, social mapping, and observation. See Annex 5 of the main report for a summary of the main findings of each of the ten QPES villages ${ }^{39}$ QPES (2001).

${ }^{40}$ World Bank estimates based on ENCOVI 2000/INE
} 
Civil Conflict. A similar correlation is evident between patterns of conflict and health outcomes. In December 1996, Guatemala ended 36 years of internal armed civil conflict when the government and the Unidad Revolucionaria Nacional Guatemalteca agreed to a ceasefire and signed the "Agreement on a Firm and Lasting Peace."41 During the civil war, the military led a campaign of terrorism and genocide against the Mayan groups, with their main objective being the distribution of the native people's land to plantation owners. Several hundred villages were destroyed and their inhabitants were either killed or forced into exile to Mexico. For the indigenous rural population, the positive outcomes of the peace accords have yet to materialize. Geographical and language barriers continue to exclude this group from the social, economic, and political life of the country, and past socioeconomic isolation and under-investment in rural infrastructure is reflected in higher rates of morbidity and mortality among these people.

The latest ENCOVI/INE 2000 figures confirm the existence of a very marked socioeconomic difference in child nutritional status among indigenous and non-indigenous groups. The prevalence of stunting in children of ladino (non-indigenous) families is about 33 percent, while it is almost 60 percent among children of indigenous families. In particular, among the different ethnic groups, children of Mam and the other Mayan families appear to be most disadvantaged; the prevalence of severely stunted children among these groups averages around 40 percent.

Table 1.21: Prevalence of Child Malnutrition by Ethnicity (Children under 5)

\begin{tabular}{l|cccccc}
\hline & Stunted & $\begin{array}{c}\text { Severely } \\
\text { Stunted }\end{array}$ & Wasted & $\begin{array}{c}\text { Severely } \\
\text { Wasted }\end{array}$ & Underweight $\begin{array}{c}\text { Severely } \\
\text { Underweight }\end{array}$ \\
\hline Total & 44.2 & 22.3 & 2.8 & 0.9 & 22.3 & 5.1 \\
Ethnicity & & & & & & \\
Indigenous & 57.6 & 30.0 & 2.6 & 1.2 & 27.8 & 7.2 \\
$\quad$ K'iche & 59.0 & 30.2 & 3.7 & 1.8 & 27.7 & 7.7 \\
Q'ueqchi & 44.8 & 16.9 & 3.3 & 1.4 & 18.7 & 5.2 \\
Kaqchiquel & 54.5 & 22.2 & 1.1 & - & 19.9 & 3.1 \\
Mam & 65.3 & 41.2 & 1.6 & 0.5 & 39.4 & 10.5 \\
Other Mayan & 62.5 & 37.4 & 3.4 & 2.2 & 31.9 & 9.1 \\
Other Indigenous & 35.9 & 12.5 & 3.2 & - & 6.3 & - \\
Non-indigenous & 32.5 & 15.5 & 3.0 & 0.6 & 17.4 & 3.3 \\
\hline
\end{tabular}

Note Children $<5$.

Source World Bank calculations using the ENCOVI 2000, Instituto Nacional de Estadisttca - Guatemala

Other Issues. However, poverty and conflict are only part of the problem. Within Latin America, Central America provides a close comparative context within which it can be seen that issues other than poverty and conflict contribute to Guatemala's health problems. Guatemala has the worst health outcomes in Central America, even though it is neither the poorest country in the sub-region nor the only one to have suffered from prolonged and violent conflict. El Salvador and Nicaragua have also recently emerged from prolonged conflict and they are doing significantly better, with higher per capita GDP growth, lower mortality rates, lower malnutrition, and higher life expectancy (see Table 1.22 below). Clearly other factors - both on the supply side and the demand side - contribute to Guatemala's poor health performance. These are discussed in the next two sections.

${ }^{41}$ Amnesty International (1998). 
Table 1.22 -Health Indicators in Central American Countries

\begin{tabular}{lccccccc}
\hline & GUA & ES & NIC & HON & CR & PAN & LAC \\
\hline Population & & & & & & & \\
Total (Mn),1999 & 11.1 & 6.2 & 4.9 & 6.3 & 3.6 & 2.8 & 508.2 \\
Growth (\%) 1980-99, avg annual & 2.6 & 2.2 & 27 & 3.0 & 2.4 & 1.9 & 1.8 \\
\% Urban, 1999 & 40 & 46 & 56 & 52 & 48 & 56 & 75 \\
GDP PC, \% growth 1998-99 & 0.9 & 1.4 & 4.3 & -4.5 & 6.1 & 1.2 & -1.5 \\
Public Expenditures (\% GDP) & & & & & & & 21.0 \\
Total (1998) & $13.0^{* *}$ & 15.1 & - & $7.2^{*}$ & 21.9 & 27.9 & 3.2 \\
Health, Public (most recent yrs) & $11^{* *}$ & 2.6 & 8.3 & 3.9 & 5.2 & 4.9 & 4.1 \\
Education, Public (1999) & $2.2^{* *}$ & 2.1 & 24 & 3.4 & 4.5 & 4.4 & \\
Health Indicators & & & & & & & \\
Infant mortality (1999) & 40 & 30 & 34 & 34 & 12 & 20 & 30 \\
Life expectancy (1999) & 65 & 70 & 69 & 70 & 77 & 74 & 70 \\
Malnutrition (last avallable) & 44 & 23 & 25 & 25 & 39 & - & 16 \\
\hline
\end{tabular}

Sources: WDI 2001. * CEPAL,(1999) Data refer to 1996-97, **World Bank (2000).

\section{II: Supply-side Obstacles to Better Health Outcomes}

Guatemalan health sector is characterized by several features that reduce its effectiveness in addressing the people health needs. In the following sections the main issues are presented.

\section{The Fragmentation of the Health Care Sector}

The Guatemalan population has limited contact with both the public and the private delivery system. A major obstacle to the provision of adequate health care service is the fragmentation of the health care system and the lack of coordination between different services which often ends up in duplication.

The Organization of the Health Care Sector. As is often the case in Latin America, the major actors in Guatemala's health sector are the Ministry of Public Health and Social Assistance (MPSAS), the Guatemalan Social Security Institute (IGSS), the private-for-profit sector, and private voluntary organizations.

The Ministry of Pubic Health and Social Assistance (MSPAS) is responsible for providing curative and preventive care for the entire population and is the largest actor in the health care system. It provides its services at practically no charge to the users. It also has the constitutional responsibility for defining health sector policies and for coordinating the different actors in the sector. The MSPAS has a central administrative level, eight regions, and 27 health areas. The MSPAS's delivery system operates on three levels: (i) the first level offers services through community centers, which constitute the simplest public health facility, and health posts, which provide preventive and primary health care and some curative services; (ii) the second level comprises health centers of either type A (with some beds, primarily for maternal care) or type B (without beds, ambulatory care only); and (iii) the third level is made up of general and specialized hospitals, which provide curative care. The community centers are located in the most remote areas and are staffed by voluntary community members who are trained by the MSPAS. They are visited by doctors and health technicians on a regular basis (at least once a month). The health posts are usually staffed by an auxiliary nurse and, at times, by a rural health technician. The health centers are typically staffed by a doctor, a nurse, an auxiliary nurse, a rural health technician, administrative personnel, and, at times, a laboratory technician and a dentist. 
The Guatemalan Social Security Institute (IGSS) provides retirement benefits and health services to those workers and their families in the formal sector who are covered, and it runs its own health facilities separate from those of MSPAS. While members of the IGSS can use MSPAS facilities, only affiliated members can use IGSS facilities. IGSS's two main programs are its Inalidez, Vejez y Sobrevivencia (IVS) program and its Enfermedad, Maternidad y Accidentes (EMA) program. The IVS, created in 1977, provides coverage to workers employed by firms with three or more employees in Guatemala City and with five or more employees in the rest of the country. The EMA was created in 1978 to cover the capital and four other departments and has since slowly expanded in coverage.

Although IGGS has a national scope, its programs have different geographic coverage. For this reason, employers' and employees' payments vary geographically according to the services provided in each area. The government has accumulated a large financial debt to IGSS, which is usually considered as one of the reasons why IGSS cannot extend its coverage and improve its quality. ${ }^{42}$

In 1995, the coverage rate of IGSS (16 percent) was about the same as in other Central American countries, such as El Salvador (14 percent), Honduras (14 percent), and Nicaragua (18 percent), but was much lower than that of Costa Rica ( 85 percent) and Mexico ( 49 percent). Per capita expenditure on IGSS is the fifth lowest in the whole Latin America and the Carbbean Region (Table 2.1).

Table 2.1: Coverage and Per Capita Expenditure on Social Insurance Systems, Latin America and the Caribbean - 1995

\begin{tabular}{l|c|c}
\hline Country & $\begin{array}{c}\text { Percentage of Population } \\
\text { Covered }\end{array}$ & Per Capita Expenditure (\$US) \\
\hline Chile & 87 & 169 \\
Costa Rica & 85 & 178 \\
Uruguay & 63 & 461 \\
Panama & 61 & 153 \\
Argentina & 59 & 375 \\
México & 49 & 115 \\
Venezuela & 36 & 85 \\
Peru & 30 & 105 \\
Bolivia & 19 & 80 \\
Ecuador & 19 & 64 \\
Paraguay & 19 & 61 \\
Nicaragua & 18 & 37 \\
Guatemala & 16 & 74 \\
El Salvador & 14 & 82 \\
Honduras & 14 & 30 \\
Colombia & 11 & 243 \\
Dominican Republic & 7 & 104 \\
\hline Soure: PAHO & 19 & \\
\hline
\end{tabular}

Source: PAHO 1998.Health in the Americas. Volume I.

The remaining health services in Guatemala are provided by the Armed Forces and Police health network, by NGOs and chantable organizations, and by the private, for-profit sector. There are two types of private, for-profit providers: (i) the folk curers, herbalists, and other practitioners of traditional medicine who predate the public health sector and now coexist with it; and (ii) the

${ }^{42}$ In 1997, the government's debt to IGSS was estımated to be about Q148,1 million. 
providers of the private modern sector, which has grown primarily in the urban areas fueled by rising incomes and dissatisfaction with the quality of public sector care. In addition to providing medical services, the private sector offers private insurance and prepayment schemes, produces pharmaceuticals, and sell medicines and medical equipment. In fact, in the latter two categories, the private sector is the major player. For example, private pharmacies and other sellers of drugs account for the large majority of the value of all sales of medicines. The state provides only a limited amount of regulation and control on the sale of medicines.

The NGO market is characterized by two types of organizations. The first kind consists of international voluntary organizations with local affiliates who have access to international funds, a diversified menu of projects, considerable experience in the sectors they specialize, and sophisticated administrative apparatus. The second kind is national NGOs that vary in size and institutional ability but, in general, have small budgets and weak administrative infrastructure. Some have had extensive experience of providing health care. Among them are a number of religious organizations who are unique in their commitment to service provision. However, they tend to specialize, with some NGOs developing a proficiency in maternal and child health, for example. Others specialize in child survival and reproductive health. An increasing number offer services in traditional medicine. 


\section{Box 1: Traditional Health Practitioners}

In all those communities where there is no health post or no national health service, the comadrona (midwife), the curandero (herbalist), and the $a j q^{\prime} i j$ (the Mayan priest) offer traditional and culturally acceptable health services, together with the promodor de salud, (health official) which were installed by the SIAS program.

These specialists of traditional medicine do not work full tıme but only when someone is sıck and ask for their help. In general, their therapeutic activity complements their occupations. They tend not to have prefixed fees for their treatments but receive the amount of money that their clients are willing to pay or sometımes they are paid in-kınd (with chıcken, maize, beans, or flour, for example). They live in very poor conditions and often have inadequate housing and facilities. They are often illiterate or poorly educated.

The Comadrona normally treats pregnant and women durng delivery or serves as a gynecologist and sometımes a pediatrician. She is normally a woman in her forties, married or a widow, a mother or a grandmother, who shares with her patient the same language, values, and cultural beliefs. Over the last 10 years, comadronas have been integrated into the mannstream health system, by receiving training aimedat reducing maternal and neonatal mortality. She receives remuneration for the treatment that she offers that normally fluctuates between $100 \mathrm{Q}$ and $300 \mathrm{Q}$ depending on the village or the region. Note that the comadrona is triply discriminated against for being a woman, indigenous, and poor. This has become more severe lately when comadronas have referred patients to a hospital in case of complications during delivery In those cases, the family of the patient often treats the comadrona as incompetent, and, in some cases, they do not pay her for her help nor for accompanying them to the hospital Members of the family often complain about the comadronas simply because they are not allowed to be with the patient during the delivery of the baby, or because they do not know what is going on, and because they are hungry and cold on their way to the hospital.

In some regions of Guatemala, the comadrona also accompanies men in their search for a wife.

The Curandero is another traditional figure who deals with the physical and psychic well being of society. $\mathrm{He}$ is believed to have special abilities that give him direct contact with superior forces of which he is the mediator. He normally treats diseases such as eye problems, anger, and indigestion. He uses medicinal plants, candles, and other animal resources like black cocks, dogs' hair, turkey feathers, animal grease, tarantulas' legs, and animal blood.

The $a j q^{\prime} y j$, or Mayan priest, is not only responsible for the health of the village but also for the counting of the days in relation to the Mayan calendar that indicates when to celebrate seed-time and harvesting. He is normally an expert in herbs, from the ones used for rituals, like tobacco, to the medicinal ones used for treating ailments.

Sources: QPES, 2001 and. MSPAS, OPS/OMS (2001)

Incomplete National Coverage and Inefficiencies: The Reform of the Health System._The Peace Agreements, which were signed in December 1996, aimed not only to end the armed conflict but also to reformulate the country's economic and social development agenda. On the health side, the Agreements called for large changes in the health sector and committed the MSPAS to demonstrating results after four years by increasing funds for preventive health, increasing community participation, and decentralizing services.

Before the Peace Agreements were signed, Guatemala had health conditions that compared poorly with those of Latin American countries at a similar stage of development. Life expectancy at birth was 65 years, and infant mortality 46 per 1,000 burths. Moreover, morbidity and mortality rates were much higher in rural areas and among indigenous populations. 
The main concern at that point was the lack of coverage of the national health system. In 1996, it was estimated that 46 percent of the population were outside the areas served by the health centers and health posts. In other words, they had no access to any health service. It was also estimated that, in 1997, the Metropolitan region, where 21 percent of the Guatemalan population lived, was absorbing 42 percent of all health expenditures. Moreover, up to 51 percent of these actual expenditures was spent on curative care, while only 28 percent was invested in promoting a better health environment and better maternal and infant health. Until 1996, MSPAS's primary health activity was concentrated in 860 health posts, each of which covered about 2,000 individuals. In addition, 318 health centers, with a coverage rate of about 10,000 people per center, were providing primary- and secondary-level medical care. There were no agreements with other health service providers, and community participation was limited to vaccination day meetings. $^{43}$

When the new government took office in 1996, it started the process of modernizing the MSPAS.

The specific public health objectives are described below.

- Regarding public expenditures on health, the aim was to increase actual spending on health by 50 percent between 1995 and 2000 and to ensure that at least 50 percent of the health budget was devoted to preventive health.

- There was a goal of reducing infant and maternal mortality by 50 percent between 1995 and 2000.

- Polio eradication certification was to be maintained and measles were to be eradicated by 2000.

- All health care delivery was to be decentralized to ensure the availability of health programs and services at the local level.

The "Cronograma para el Cumplimento de los Compromisos de los Acuerdos de Paz"44 extended the most important targets included in the-Peace Agreements to the period 2000-2004. It also called for a specific plan for traditional and indigenous medicine to be prepared after consultation with the local communities.

As a response to the objective of the Peace Accord to expand coverage of basic services to the impoverished rural and indigenous population, the SIAS system (Sistema Integrado Atención de Salud) was introduced in 1997 with financing from the IDB Health Reform Loan. The SLAS system is defined as being responsible for the organization and administration of basic services and the resources of the health sector, according to different levels of care and administration, with the aim of: (i) extending coverage to those groups of the population that traditionally have limited access and (ii) improving the quality of health services according to criteria of equity, solidarity, and universality, in a sustainable and efficient way.

The program deals with both preventive and curative care with the aim of establishing services closer to most communities and of encouraging the participation of different members of the community in administration of the program.

\footnotetext{
${ }^{43}$ CIEN (2000).

${ }^{44}$ Chronogram for the Accomplishment of the commitments contained in the Peace Accords.
} 
NGOs, cooperatives, municipalities, and the social security system are among the most important organizations involved in implementing the SIAS program. In order to participate in SIAS, an organization must be legally recognized, have minimal infrastructure, and have some institutional experience. In 2000, a total amount of 103.4 million Q was transferred to such institutions to help them to provide health care services at the community level. The budget for SIAS is almost completely financed by the Ministry of Public Health and Social Assistance.

As part of the broader effort to implement organizational, institutional, and financial reforms in the health sector, Guatemala adopted a model to extend basic services to poor populations. The Program to Extend Coverage to of Basic Health Services (Programa de Extension de Cobertura de Servicios Basicos) or PCEBS started in 1997 as part of SLAS. It was established when the Government of Guatemala signed the first set of pilot agreements (convenios) through which four NGOs were contracted to extend basic services to impoverished indigenous populations living in rural hamlets with little or no access to health services. By early 2000, the MSPAS had signed 137 convenios with 89 NGOs for a total coverage of 3 million people (25 percent of the total population).

Figure 2.1 illustrates the success of PECBS in extending coverage. The percentage of population without access to health services declined from 46 percent in 1996 to 9 percent in late 1999.

Figure 2.1: Coverage of Guatemalan Population Before and After SIAS

1996

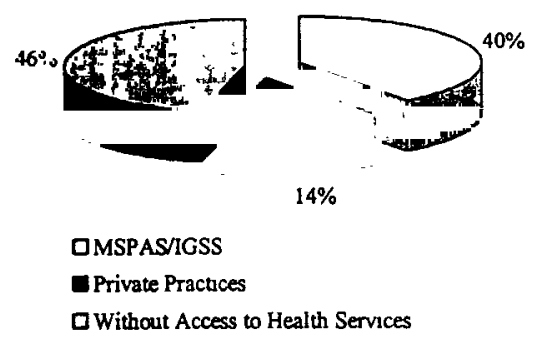

December 1999

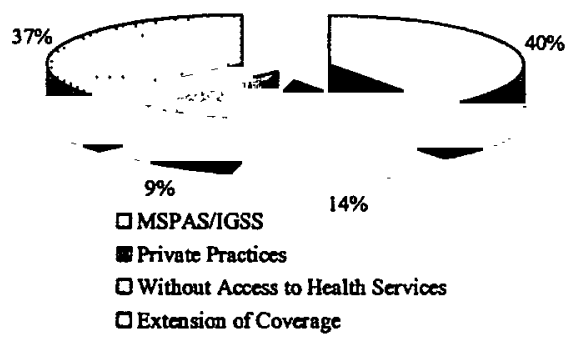

Source MSPAS

Under the convenios with the MSPAS, NGOs perform two distinct functions: (i) provision and (ii) administration of services. Health providers, known as PSSs (Prestadoras de Servicios de Salud), directly provide the basic SIAS package of services to families. This basic package includes: maternal health care, ${ }^{45}$ pre-school and school-age children's health, ${ }^{46}$ illness management and emergency care, ${ }^{47}$ and environmental services. ${ }^{48}$ Health service administrators or ASSs (Administradora de Servicios de Salud) operate exclusively as administrators, financial managers, and payers for MSPAS primary care proviaers and to a lesser extent, for PSSs. ${ }^{49}$

\footnotetext{
${ }^{45}$ The maternal health services include: prenatal care, tetanus toxoid, iron, folic acid supplementation during pregnancy, delivery, postpartum care, birth spacing (education and referral), detection of cervical and breast cancer, and referral of emergencies.

${ }^{40}$ The child and school age health program includes. immunizations, ARI management, diarrhea/cholera management, vitamin A and iron supplementation, growth monitoring of children under two years old, and referral of emergencies.

${ }^{47}$ The illness management and emergency care program includes: vector control, zoonosis and rabies control, tuberculosis control, STD/HIV and AIDS control, diarrhea and cholera control, and referral of emergencies.

${ }_{48}$ The environmental services program includes monitoring of water quality, promotion of sanitary disposal of waste, and the improvement of household sanitary conditions and food hygiene.

${ }^{49}$ La Forgia, Nieves, and Ribera (2000).
} 
In order to assess the program's performance, an impact evaluation study of a sample of areas is currently being done. Preliminary information indicates that immunization coverage rates have increased as well the monitoring of normal pregnancies by medically trained health specialists.

The main objective of MSPAS for the 2000-2004 period is to define and implement the National Health Plan (Plan Nacional de Salud), which aims to deliver adequately managed health care to the Guatemalan population, ensure universal access to health services, and guarantee that the population receives care that is characterized by ethics, quality, and equity.

The development of the National Health Plan is based on the following strategies:

- Decentralization with social and community participation.

- Primary health care at all levels of services provision with emphasis on providing information and creating self-awareness and responsibility.

- Equity, efficiency, quality, and socral, technological and financial sustainability with a focus on the most disadvantaged groups.

The following health policies provide the guiding principles for the implementation of the National Health Plan:

- Household-level integrated health

- Health for indigenous people with a focus on women

- Health for migrant population

- Integrated health development and strengthening for other groups

- Extension of coverage of basic health services with quality and sustainability

- Basic sanitation and environmental development

- Access to basic drugs and traditional medicıne

- Strategic development of human resources

- Institutional development and decentralization

- Intra- and inter-sectoral coordination.

- Improvement and optimization of donors' cooperation

- Development of the health sector financial system.

\section{The Low Level of Public Spending on Health Care}

During 1996-1997, Guatemala had the second lowest per capita public spending on health (US\$16) among the Latin American countries for which data are available. Only Bolivia had a lower figure 
(US\$14) in the region. Per capita spending on health by the Governments of Panama and El Salvador was approximately thirteen and three times as high as that of Guatemala respectively (Table 2.2).

Table 2.2: Public Social Spending in Latin America, 1996-1997

\begin{tabular}{|c|c|c|c|c|c|c|c|}
\hline \multirow{3}{*}{ Country } & \multicolumn{5}{|c|}{ Per Capita Social Expenditures (in 1997 US\$) } & \multirow{2}{*}{\multicolumn{2}{|c|}{ Social Spending as Share of: }} \\
\hline & Total 1/ & Education & Health 2/ & $\begin{array}{c}\text { Social } \\
\text { Security }\end{array}$ & $\begin{array}{l}\text { Housing/ } \\
\text { Water 3/ }\end{array}$ & & \\
\hline & & & & & & GDP & Total Expenditure \\
\hline$\overline{\text { Argentina }}$ & $\overline{1,570}$ & 334 & 362 & 704 & 110 & $17.9 \%$ & $65.1 \%$ \\
\hline Uruguay & 1,371 & 185 & 224 & 931 & 30 & $22.5 \%$ & $69.8 \%$ \\
\hline Panama & 683 & 172 & 210 & 206 & 59 & $21.9 \%$ & $39.9 \%$ \\
\hline Costa Rica & 550 & 153 & 193 & 146 & 52 & $20.8 \%$ & $65.1 \%$ \\
\hline Brazil & 951 & 164 & 138 & 487 & 162 & $19.8 \%$ & $59.1 \%$ \\
\hline Chile & 725 & 167 & 128 & 342 & 59 & $14.1 \%$ & $65.9 \%$ \\
\hline Colombia & 391 & 113 & 95 & 137 & 36 & $15.3 \%$ & $38.2 \%$ \\
\hline El Salvador & 147 & 50 & 54 & 39 & 5 & $7.7 \%$ & $26.5 \%$ \\
\hline Venezuela & 317 & 119 & 42 & 110 & 47 & $8.4 \%$ & $39.0 \%$ \\
\hline Rep. Dominicana & 107 & 41 & 24 & 12 & 7 & $6.0 \%$ & $39.0 \%$ \\
\hline Paraguay & 148 & 72 & 22 & 49 & 4 & $7.9 \%$ & $47.1 \%$ \\
\hline Guatemala & 71 & 28 & 16 & 12 & 16 & $4.2 \%$ & $42.1 \%$ \\
\hline Bolivia & 119 & 59 & 14 & 27 & 20 & $12.0 \%$ & $44.2 \%$ \\
\hline México & 352 & 153 & n.d. & n.d. & n.d. & $7.8 \%$ & $52.9 \%$ \\
\hline Penú & 169 & n.d. & n.d. & n.d. & n.d. & $5.8 \%$ & $40.9 \%$ \\
\hline Honduras & 58 & n.d. & n.d. & n.d. & n.d. & $7.2 \%$ & $31.9 \%$ \\
\hline LAC average 4/ & 457 & 122 & 110 & 229 & 44 & $10.1 \%$ & $47.2 \%$ \\
\hline
\end{tabular}

Source: CEPAL (1999) I/ The difference between the sum of the sub-sector amounts and total per-capita spending consists of 'other social spending' 2/Included spending on nutrtion 3/Includes housing, water \& sewerage 4/ The LAC average under each category is based on the countries for which the corresponding information is available.

Per capita public spending on health in Guatemala remained very low during 1998-2000 (Table 2.3). Between 2000 and 2001, overall public spending on health is expected to have increased from US $\$ 200$ million to US\$274 million, (37 percent) and per capita spending is expected to have increased from US\$17.5 to US\$23.3 (24.9 percent). ${ }^{50}$

\footnotetext{
${ }^{50}$ Such an increase is likely to be about 10 percent smaller since the 2001 figure refers to a budgeted value while the 1998,1999 , and 2000 figures refer to actual values. The proportions of actual spending were 91.6, 89.6, and 94.2 percent of budgeted spending in 1998, 1999, and 2000 respectively.
} 
Table 2.3: Public Social Spending in Guatemala, 1998-2000 (US\$)

\begin{tabular}{|c|c|c|c|c|}
\hline & 1998 & 1999 & 2000 & 2001 \\
\hline & & Actual & & Budgeted \\
\hline Health and Social Assistance & $183,345,544$ & $214,736,493$ & $200,729,616$ & $274,705,790$ \\
\hline Labor and Socıal Security & $163,801,142$ & $160,741,311$ & $196,408,379$ & $178,967,234$ \\
\hline Education & $381,151,047$ & $415,160,431$ & $433,636,895$ & $525,595,298$ \\
\hline Culture and Sport & $25,367,496$ & $26,225,402$ & $33,156,764$ & $44,522,534$ \\
\hline Science and Technology & 863,615 & $1,172,775$ & 885,362 & $16,316,349$ \\
\hline Water and Sanitation & $29,370,058$ & $40,382,189$ & $43,831,160$ & $64,385,776$ \\
\hline Housing & $104,864,060$ & $54,052,101$ & $1,366,192$ & $29,989,888$ \\
\hline Urban and Rural Development & $189,270,872$ & $177,148,512$ & $160,621,433$ & $250,536,484$ \\
\hline Environment & $2,429,401$ & $5,123,584$ & $13,584,092$ & $18,936,829$ \\
\hline Other social sector activities & $28,633,412$ & $18,564,431$ & $41,243,175$ & 537,136 \\
\hline Total Social Sectors & $1,109,096,646$ & $1,113,307,229$ & $1,125,463,068$ & $1,404,493,318$ \\
\hline Total & $2,589,743,203$ & $2,591,717,043$ & $2,551,696,031$ & $2,532,117,800$ \\
\hline Health Spending/Social Spending & $16.5 \%$ & $19.3 \%$ & $17.8 \%$ & $19.6 \%$ \\
\hline Health Spending/Total Spending & $7.1 \%$ & $8.3 \%$ & $7.9 \%$ & $10.8 \%$ \\
\hline Per capita public spending on health & 170 & 19.3 & 175 & 23.3 \\
\hline
\end{tabular}

Source. SIAF 1998, 1999, 2000, 2001

\section{Ineffective Composition of Public Spending}

Public Spending in Guatemala is mainly used for current actıvities and skewed towards people in the highest quintiles, as shown in the following sections.

Functional and Economic Composition. Table 2.4 presents the economic classification of public spending on health in the 2001 budget. As is often the case in Latin America, the large majority of public spending is used for current activities ( 81.0 percent), which comprise mostly wages and salaries, leaving little room for investment and maintenance activities.

Table 2.4: Economic Classification of Ministry of Health and Social Assistance Spending, 2001

\begin{tabular}{l|ccc}
\hline & Capital & Current & Total \\
\hline Value (Quetzales) & $40,242,949$ & $171,722,773$ & $211,965,722$ \\
Percentage & $19.0 \%$ & $81.0 \%$ & $100.0 \%$ \\
\hline
\end{tabular}

Source Presupuesto General de Ingresos y Egresos del Estado (2001)

Figure 2.2 shows the functional classification of public spending by the MSPAS, as indicated by the actual expenditures for 1997. Despite the fact that Guatemala is in the early stage of the demographic and health transition as described in Part I, which will require large investments in primary and preventive care, more than half of the 1997 budget (54 percent) was spent on curative care (mostly public hospitals). Only 30 percent of the resources were invested in preventive care. 
Figure 2.2: Functional Classification of Ministry of Health and Social Assistance Spending Actual Spending, 1997

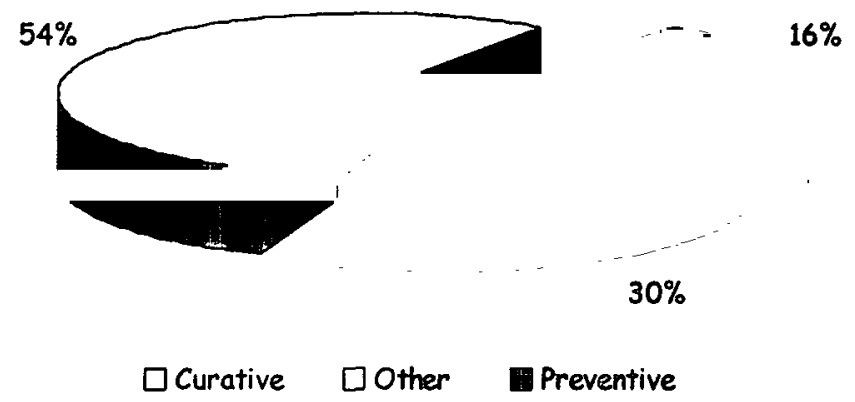

Source: IDC, Revisión del Programa de Inversión Publica de Mediano Plazo, Guatemala, Nov. 1998

Over four-fifths of spending on health for 2001 was expected to be financed by internal resources, mostly transfers of public revenues from the Minister of Finance (Table 2.5). The proportion of external financing is very low (14 percent), most of which is in the form of grants (11 percent of overall financing).

Table 2.5: Sources of Financing of Ministry of Health and Social Assistance, 2001

\begin{tabular}{l|cc|cc|c}
\hline & \multicolumn{2}{|c|}{ Internal } & \multicolumn{2}{c|}{ External } & Total \\
\hline & Transfers & Own Revenues & Loans & Grants & \multirow{2}{*}{. } \\
Value (Quetzales) & $174,802,752$ & $7,361,509$ & $5,626,598$ & $24,174,863$ & $211,965,722$ \\
Percentage & $82.5 \%$ & $3.5 \%$ & $2.6 \%$ & $11.4 \%$ & $100.0 \%$ \\
\hline
\end{tabular}

Source: Presupuesto General de Ingresos y Egresos del Estado (2001).

Poorly Targeted Spending. The purpose of benefit-incidence analysis is to estimate how much different groups benefit from public resources devoted to health. We analyzed the incidence of government spending on health by consumption quintile. To conduct benefit-incidence analysis, we used three different kinds of information: (i) the utılization patterns of health care facilities by the Guatemalan population; (ii) the average cost to the government of providing health care services in different health care facilities; and (iii) the out-of-pocket payments of individuals who use different health care facilities. ${ }^{51}$ The data on utilization patterns and out-of-pocket expenditure came from ENCOVI/INE 2000 while data on the average cost of different health facilities came from MSPAS. ${ }^{52}$

Tables 2.6a and 2.6b show the utilization pattern of different health facilities. The poorest people use health facilities the least, regardless of what type of facility is in question. ${ }^{53}$ The poorest 40 percent of the population account for only 26 percent of the use of all facilities. Moreover, there is a general tendency for the population - even for the poorest - to use private rather than the public facilities as shown in Table 2.6b, which shows that 40 percent of all of the facilities visited during the month prior to the interview were private hospitals or clinics. Among private facilities, clinics are visited more often than hospitals. The poor quality of the services offered in public health facilities is usually considered to be a reason why they are underutilized.

\footnotetext{
${ }^{51}$ See Demery (1997) and Deaton (1997) for descriptions of the conceptual and empirical issues involved in doing benefitincidence analysis.

52 GETSA (2001).

${ }^{53}$ The utilization of health services in Guatemala is very low, with only 10 percent of the population visiting any health facility (public or private) during the month prior to the interview The figure increases to 43 percent among those who were sick or had had an accident.
} 
Table 2.6a: Utilization Pattern of Health Care Facilities Proportion Of Visits per Health Facility

\begin{tabular}{l|cccccc}
\hline Health Facility & Q1 & Q2 & Q3 & Q4 & Q5 & Total \\
\hline Hospital & 11 & 16 & 19 & 29 & 26 & 100 \\
Health center & 23 & 22 & 22 & 25 & 13 & 100 \\
Health post & 25 & 26 & 29 & 15 & 5 & 100 \\
Community center & 26 & 21 & 19 & 19 & 15 & 100 \\
Private Hospital and Clinic & 3 & 9 & 12 & 22 & 53 & 100 \\
All Facilities* & 11 & 15 & 18 & 22 & 34 & 100 \\
\hline
\end{tabular}

* Includes hospital IGSS, pharmacy, and other structures in addution to the ones above.

Source-World Bank calculations using the ENCOVI 2000, Instituto Nactonal de Estadistica - Guatemala

Table 2.6b: Utilization Pattern of Health Care Facilities Proportion of Visits per Consumption Quintile

\begin{tabular}{l|cccccc}
\hline Health Facility & Q1 & Q2 & Q3 & Q4 & Q5 & Total \\
\hline Hospital & 11 & 12 & 13 & 15 & 9 & 12 \\
Health center & 23 & 22 & 19 & 16 & 6 & 15 \\
Health post & 17 & 14 & 13 & 5 & 1 & 8 \\
Community center & 4 & 3 & 2 & 2 & 1 & 2 \\
Pnvate Hospital and Clinic & 11 & 24 & 28 & 40 & 62 & 40 \\
All Faclities* & 100 & 100 & 100 & 100 & 100 & 100 \\
\hline
\end{tabular}

* Includes hospital IGSS, pharmacy, and other strictures in addition to the ones above.

Source: World Bank calculations using the ENCOVI 2000, Instituto Nactonal de Estadistica-Guatemala

Table 2.7 presents the unit cost of a visit to different public health facilities, in other words, how much a visit to each facility costs, on average, to the government. The cost of a visit to a hospital is four times as high as the cost of a visit to a health center or community center, and is almost eight times as high as a visit to a health post.

Table 2.7: Unit Cost to the Government per Visit (Gross Public Subsidy) by Type of Health Facility

\begin{tabular}{cccc}
\hline Hospital & Health center & Health post & Community center \\
\hline 120.2 & 292 & 17.1 & 31.4 \\
\hline
\end{tabular}

Source: MSPAS, World Bank-GETSA-MSPAS (200I)

Average expenditure per visit to a public health facility tends to be higher for richer people (Table 2.8). On average, individuals in the highest quintile spend almost nine times more than those in the bottom quintile spend on all public health facilities. However, the ENCOVI/INE data indicate that most people do not pay anything for their visits to any public health facility. The proportion of people who receive health care for free is highest in the poorest quintile ( 70 percent) but is still high in the richest quintile (59 percent). The higher average cost is therefore due to a limited number of individuals who pay for special and expensive treatments in exceptional circumstances. 
Table 2.8: Average Out-of-Pocket Household Expenditure per Visit by Type of Health Care Facility

\begin{tabular}{l|ccccccccccccc}
\hline Health Facility & \multicolumn{3}{|c}{ Q1 } & \multicolumn{1}{c}{ Q2 } & \multicolumn{1}{c}{ Q3 } & \multicolumn{1}{c}{ Q4 } & \multicolumn{3}{c}{ Q5 } & \multicolumn{3}{c}{ Total } \\
\hline & Last Month & Qtz & Zero & Qtz & \% Zero & Qtz & \% Zero & Qtz & \% Zero & Qtz & $\%$ Zero & Qtz & \% Zero \\
\hline Hospital & 13.8 & $72 \%$ & 25.2 & $59 \%$ & 28.7 & $58 \%$ & 44.8 & $60 \%$ & 111.9 & $54 \%$ & 42.7 & $60 \%$ \\
Health center & 5.6 & $62 \%$ & 5.1 & $73 \%$ & 10.4 & $64 \%$ & 12.7 & $65 \%$ & 33.8 & $65 \%$ & 13.1 & $66 \%$ \\
Health post & 2.0 & $77 \%$ & 4.8 & $66 \%$ & 8.0 & $80 \%$ & 12.2 & $71 \%$ & 1.5 & $81 \%$ & 6.7 & $74 \%$ \\
Community center & 0.8 & $79 \%$ & 1.6 & $85 \%$ & 5.6 & $50 \%$ & 36.6 & $56 \%$ & 23.1 & $36 \%$ & 8.6 & $64 \%$ \\
Any Public Facility & 5.8 & $70 \%$ & 9.8 & $68 \%$ & 14.6 & $66 \%$ & 26.3 & $64 \%$ & 72.8 & $59 \%$ & 19.4 & $66 \%$ \\
\hline
\end{tabular}

* Percentage of observations in the cell with a 0 value Note. Health expenditure refers to the cost of the visit over the last month. Source. World Bank calculations using the ENCOVI 2000, Instituto Nacional de Estadistica - Guatemala

The net public health subsidy received by any individual is calculated as the monetary value associated to his/her visits to public health care facilities, net of the payments made for his/her visits at such facilities. Table 2.9 summarizes how the net public health subsidy on health is distributed across different income groups.

Table 2.9: Share of Net Public Subsidy Received by Each Consumption Quintile

\begin{tabular}{l|cccccc}
\hline Health Facility & Q1 & Q2 & Q3 & Q4 & Q5 & Total \\
\hline Hospital & $13 \%$ & $16 \%$ & $21 \%$ & $28 \%$ & $21 \%$ & $100 \%$ \\
Health center & $20 \%$ & $23 \%$ & $28 \%$ & $20 \%$ & $9 \%$ & $100 \%$ \\
Health post & $40 \%$ & $22 \%$ & $27 \%$ & $6 \%$ & $5 \%$ & $100 \%$ \\
Community center & $39 \%$ & $20 \%$ & $23 \%$ & $8 \%$ & $10 \%$ & $100 \%$ \\
All Facilities & $17 \%$ & $18 \%$ & $23 \%$ & $25 \%$ & $17 \%$ & $100 \%$ \\
\hline
\end{tabular}

Source. World Bank calculations using the ENCOVI 2000, Instituto Nacional de Estadistica - Guatemala

Overall, the poorest 40 percent of the population receive 35 percent of the total net health subsidy (public spending on health), while the richest 40 percent recelve 42 percent. Concentration curves for the net health subsidy in each health facility are shown in Figure 2.3. ${ }^{54}$

\footnotetext{
${ }^{54}$ Concentration curves illustrate the cumulative proportion of net subsidy received by the cumulative proportion of population ranked by per capita consumption. The 45 -degree line represents the "perfect equality" situation, in other words, the line that would be obtained if each consumption quintile received the same amount of health consumption through public subsidy.
} 


\section{Figure2.3: Concentration Curves of Net Public Subsidy on Health by Type of Health Facility}

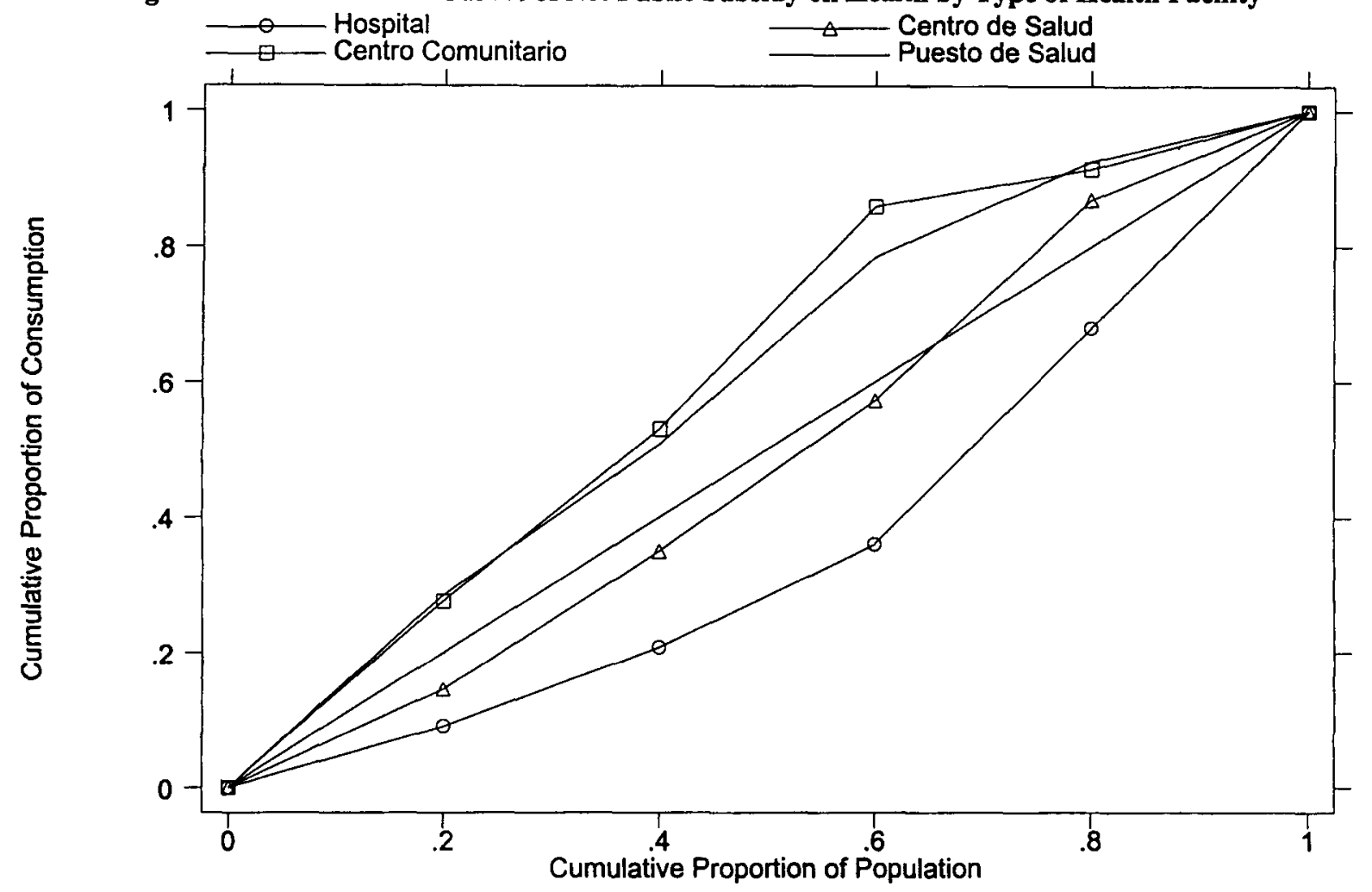

Source: World Bank calculations using the ENCOVI 2000, Instituto Nacional de Estadistica-Guatemala

Public hospitals are the most regressive facilities. The poorest quintile receives only 13 percent of the net public subsidy, while the richest quintile receives 21 percent. This is due to the higher public cost of a visit to a hospital and the tendency of richer people to use hospitals much more frequently than poorer people. Community centers and health posts, which provide basic health care services and are visited more frequently by poorer people, are the most progressive (the poorest quintile receives 39 percent and 40 percent of the public net subsidy to community centers and health posts respectively). Health centers, which are visited by people in the lowest four quintiles with a similar frequency, are in middle in terms of progressiveness.

Overall, public spending on health is slightly regressive, with the poorest 40 percent of the population recelving 35 percent of total subsidies and the richest 40 percent receiving 42 percent. The large overall degree of inequality is explained by the higher public cost of visits to public hospitals, which skews the distribution of the net public health subsidy towards richer people who visit hospitals more than others.

The system of payments in public facilities means that more costs are recovered from richer people who receive special and more expensive treatment more often than poorer people. However, most visits to any public health facility are free of charge for all individuals, regardless of their socioeconomic status, a policy that prevents the net public health subsidy from being more equitably distributed. .

The distribution of overall per capita expenditure in Guatemala is highly skewed towards richer households, which consume more than 20 times more than the poorest ones and account for more than 60 
percent of total national consumption. With a Gini coefficient of 57, Guatemala stands out as being a very unequal country. ${ }^{55}$

Table 2.10: Distribution of Total Consumption and Net Health Subsidy across Income Quintiles

\begin{tabular}{l|ccccc}
\hline & Q1 & Q2 & Q3 & Q4 & Q5 \\
\hline Share of Per Capita Consumption & $3 \%$ & $6 \%$ & $9 \%$ & $18 \%$ & $63 \%$ \\
Share of Net Health Subsidy & $11 \%$ & $14 \%$ & $17 \%$ & $30 \%$ & $28 \%$ \\
\hline
\end{tabular}

Source. World Bank calculations using the ENCOVI 2000, Instituto Nacional de Estadistica - Guatemala

Two policy options are available to make public spending more progressive. The first is to shift resources away from hospitals towards community centers, health posts, and health centers, in other words, increasing spending on primary health care. The second is to introduce cost recovery mechanisms that charge different fees according to users' income levels.

\section{Large Inequalities in Private Spending on Health Care}

Table 2.11 shows out-of-pocket expenditures on health by individuals in different consumption quintiles, in absolute terms and as a proportion of total spending. On average in Guatemala, the poorest spend 30 times less than the richest (Table 2.11). The poorest individuals tend to allocate a very low proportion of their budget to health, and only as income increases significantly do they start consuming relatively more luxurious goods and services like health care. Expenditure on health absorbs only 1.4 percent of the total consumption for individuals in the lowest quintile. The corresponding figure is 4.0 percent for individuals in the richest quintile.

\section{Table 2.11: Average Out of Pocket Household Health Consumption by Consumption} Quintiles

\begin{tabular}{l|ccccc}
\hline Last Year Expenditure & Q1 & Q2 & Q3 & Q4 & Q5 \\
\hline Average Per Capita Expenditure on Health (000 Qtz) & 173 & 357 & 589 & 1,185 & 5,527 \\
Average Relative Health Consumption (\% Tot Cons) & $1.4 \%$ & $1.7 \%$ & $2.0 \%$ & $2.5 \%$ & $4.0 \%$ \\
\hline
\end{tabular}

Note: Health Expenditure is the total health expenditure (including traveling costs, medicines, visits) during the last year. Source: World Bank calculations using the ENCOVI 2000, Instituto Nacional de Estadistica - Guatemala

Figure 2.4 shows the relationship between consumption of health care and total consumption (in logarithmic scale). The elasticity of consumption on health in total consumption is estimated do be around 1.5 , confirming that health care is seen as a luxury good by most people in Guatemala. The proportion of total consumption that households spend on health care is between 2.5 percent and 3.0 percent for more than two-thirds of the population. Only for the remaining third of the population does health care consumption start to increase, at a rapid pace, signaling that they have more resources available to "invest" in a luxury good such as health care.

\footnotetext{
${ }^{55}$ World Bank calculations based on ENCOVI/INE 2000.
} 
Figure 2.4: Proportion of Total Expenditure on Health by Percentile of Total Household Per Capita Expenditure

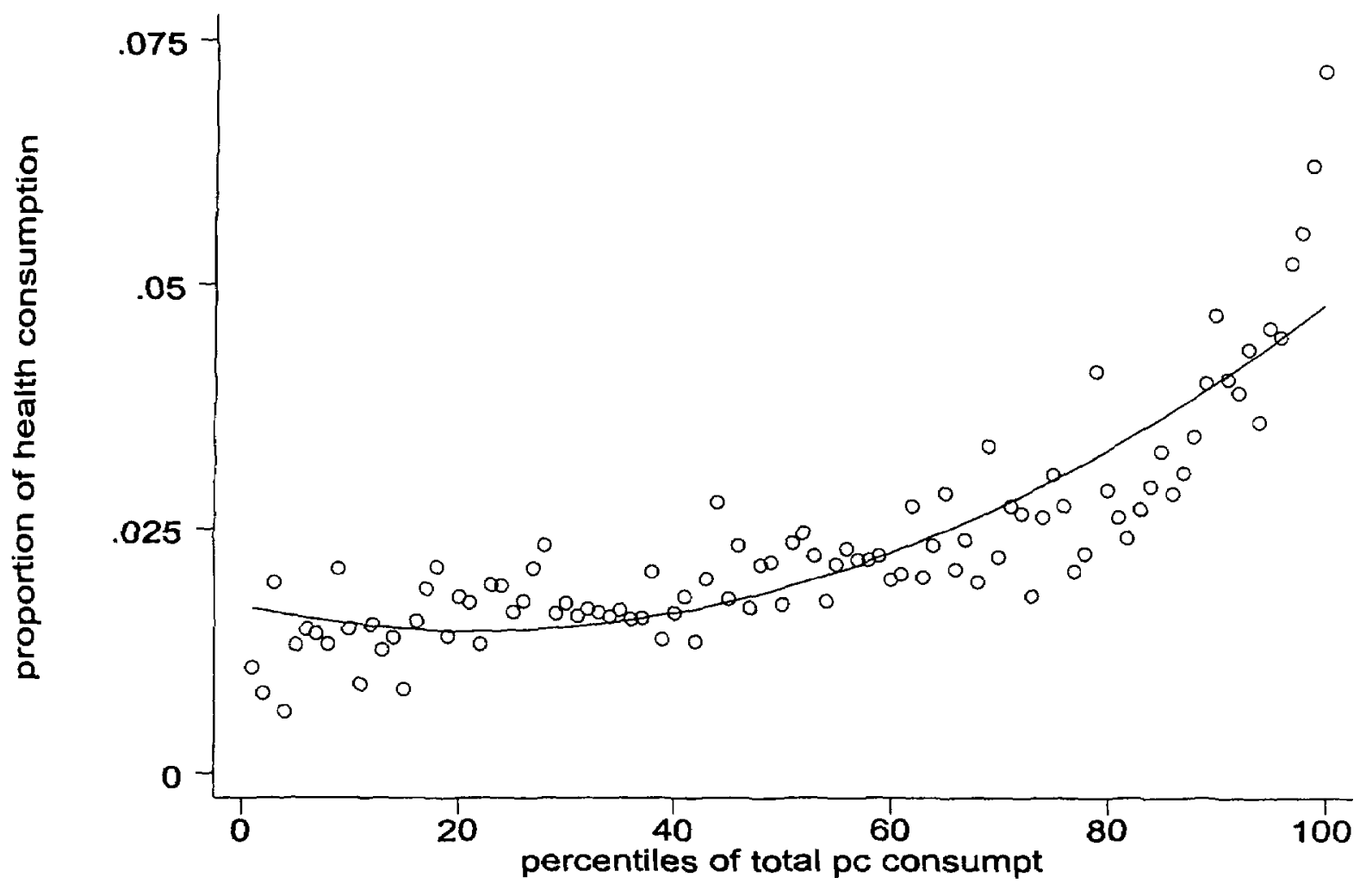

Source. World Bank calculations using the ENCOVI 2000, Instituto Nacional de Estadistica - Guatemala

Households in rural areas spend three times less on health care than households in urban areas and allocate less than 2 percent of their consumption budget to health (Table 2.12).

Table 2.12: Average Out of Pocket Households Health Consumption by Area

\begin{tabular}{l|cc}
\hline Last Year Expenditure & Urban & Rural \\
\hline Average Per Capita Expenditure on Health (000 Qtz) & 5,996 & 1,837 \\
Average Relative Consumption (\% Tot Cons) & $3.0 \%$ & $1.8 \%$ \\
\hline Source - World Bank calculations using the ENCOV7 2000, Instztuto Nacional de Estadistıca - Guatemala
\end{tabular}

Average health care consumption is lowest in the Peten, Suroriental, and Norte regions. The proportion of total spending devoted to health is lowest in the Noroccidental region, where on average only 1.7 percent of total consumption is allocated to health. The Metropolitan region, the richest and most urbanized of all Guatemala, shows the highest consumption of health (Table 2.13).

\section{Table 2.13: Average Out of Pocket Households' Health Consumption by Region}

\begin{tabular}{|c|c|c|c|c|c|c|c|c|}
\hline Last Year Expenditure & Metro & Norte & Noror & Suror & Centr & Suroc & Noroc & Peten \\
\hline Average Per Capita Expenditure on Health (000 Qtz) & 3,021 & $\overline{513}$ & 773 & 535 & 958 & 954 & 722 & 354 \\
\hline Average Relative Consumption (\% Tot Cons) & $4.0 \%$ & $2.0 \%$ & $3.0 \%$ & $2.0 \%$ & $2.5 \%$ & $2.2 \%$ & $1.7 \%$ & $1.8 \%$ \\
\hline
\end{tabular}

Figure 2.5 compares the distribution of total per capita consumption and of per capita health consumption. Health consumption includes every type of household spending on health, such as doctor visits, 
medicines, and transportation to health facilities. The distribution of private spending on health is even more unequal than that of consumption. The majority of health expenditure is concentrated in the hands of the richest individuals in the country. The richest 40 percent of the population contribute 94 percent of total private spending on health. People in the poorest quintile account for less than 1 percent of total health expenditure.

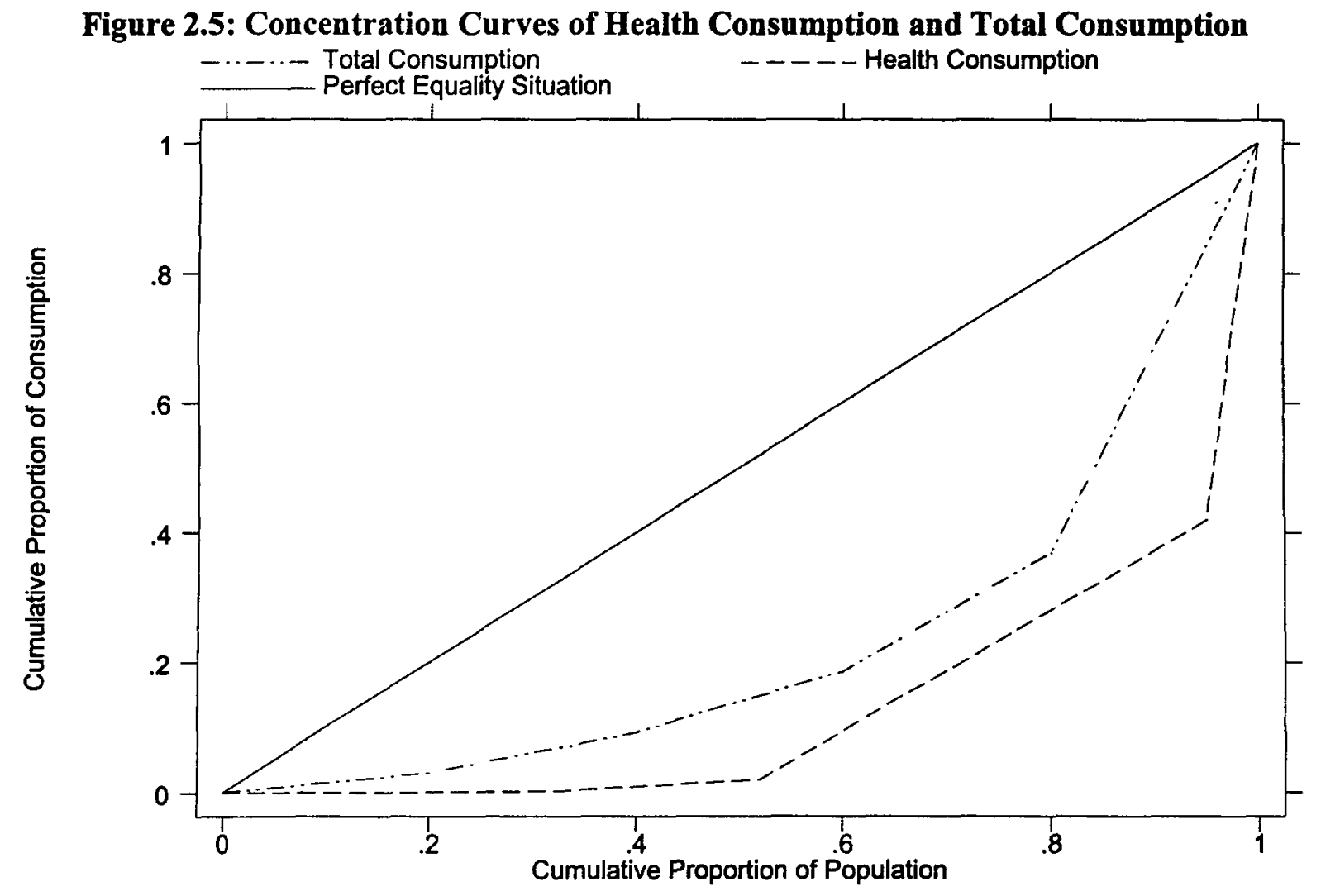

Source. World Bank calculattons using the ENCOVI 2000, Instituto Nacional de Estadistica - Guatemala

\section{Inadequate Insurance Coverage}

Health insurance coverage of any kind is very low in Guatemala. ENCOVI data indicate that only 11 percent of Guatemalans have any kind of health insurance (Table 2.14). The majority of those who have insurance are affiliated with IGGS, while the rest have private insurance. The great majority of those who have either type of health insurance belong to the richest expenditure quintiles and live in urban areas. Only 3 percent of the poorest 40 percent of the population have IGSS insurance. 
Table 2.14:Proportion of Individuals Affiliated with IGGS or Covered by Health Insurance

\begin{tabular}{l|c|ccccc|cc}
\hline & Total & $\mathbf{Q 1}$ & $\mathbf{Q 2}$ & $\mathbf{Q 3}$ & $\mathbf{Q 4}$ & $\mathbf{Q 5}$ & Urban & Rural \\
\hline Private Insurance & 2.2 & 0.0 & 0.0 & 1.0 & 2.0 & 8.0 & 5.0 & 1.0 \\
IGSS & 8.3 & 3.0 & 3.0 & 6.0 & 12.0 & 17.0 & 14.0 & 5.0 \\
IGSS and private & 0.0 & 0.0 & 0.0 & 0.0 & 0.0 & 1.0 & 1.0 & 0.0 \\
Other & 0.0 & 0.0 & 0.0 & 0.0 & 0.0 & 1.0 & 0.0 & 0.0 \\
None & 89.0 & 97.0 & 96.0 & 92.0 & 86.0 & 73.0 & 81.0 & 94.0 \\
\hline
\end{tabular}

Source World Bank calculations using the ENCOVI 2000, Instituto Nactonal de Estadistica - Guatemala

ENCOVI/NE data also show a large variation of monthly payments among those who have health insurance, a finding that underscores the fact that those who can afford insurance have both wider coverage and a better quality of services. In particular, Table 2.15 indicates that the average monthly payment for health insurance is almost 10 times as high for the richest quintile (Q95.0) as for the poorest quintile (Q10.8).

Table 2.15: Average Monthly Payment (Qtz)

\begin{tabular}{l|c|ccccc|cc}
\hline & Total & Q1 & Q2 & Q3 & Q4 & Q5 & Urban & Rural \\
\hline Private Insurance & 119.6 & 15.1 & 78.0 & 41.9 & 42.0 & 153.1 & 134.5 & 56.2 \\
IGSS & 41.7 & 10.1 & 13.6 & 32.2 & 39.2 & 57.5 & 51.6 & 242 \\
Total & 62.4 & 10.8 & 19.4 & 31.8 & 39.2 & 95.0 & 79.2 & 27.5 \\
\hline
\end{tabular}

Source: World Bank calculations using the ENCOVT 2000, Instituto Nacional de Estadlstica - Guatemala

Table 2.16 below shows the existence of duplicated subsidies among different health insurers and providers, a common source of inefficiencies in Latin American countries. On the one hand, a large number of non-IGSS members visit IGSS facilities. On the other hand, more importantly, a large proportion of IGSS affiliates receives health care in non-IGSS facilities (both private and public).

Table 2.16:Use of Health Facilities by Holders of Different Health Insurance (Percentage of Visits)

\begin{tabular}{l|ccccccccc}
\hline Type of Insurance & \multicolumn{8}{|c}{ Type of Facility } \\
\hline & $\begin{array}{c}\text { Public } \\
\text { Hospital }\end{array}$ & $\begin{array}{c}\text { Private } \\
\text { Hospital }\end{array}$ & $\begin{array}{c}\text { IGSS } \\
\text { Hospital }\end{array}$ & $\begin{array}{c}\text { Health Post } \\
\text { or Health } \\
\text { Center }\end{array}$ & $\begin{array}{c}\text { Communit } \\
\text { y Center }\end{array}$ & Pharmacy & Home & Other \\
\cline { 2 - 9 } Private Insurance & 5.3 & 17.0 & 53.0 & 7.7 & 0.3 & 6.1 & 8.3 & 2.3 \\
IGSS & 6.0 & 38.6 & 37.1 & 4.6 & 1.2 & 6.9 & 3.0 & 2.7 \\
IGSS and Private & 1.2 & 17.5 & 67.7 & - & - & 1.0 & 10.8 & 1.8 \\
Other & 3.7 & - & 65.0 & - & - & 2.2 & - & 29.1 \\
No Insurance & 10.1 & 1.3 & 39.5 & 26.9 & 2.2 & 8.3 & 5.8 & 6.1 \\
\hline
\end{tabular}

\section{III: Demand-side Factors}

The following analysis is based mainly on the household data collected by the ENCOVI 2000/INE. While not complete in terms of its coverage of health outcomes and processes, the ENCOVI 2000/INE is unique for Guatemala in terms of the representativeness of its sample, the availability of poverty variables and the richness of information on issues such as education, housing, anthropometry. 


\section{The Under-utilization of Health Services}

Public health facilities tend to be underutilized in Guatemala. If they can afford it, people often prefer to use private facilities. Poor people, on the other side, often tend to prefer to rely on assistance from other members of the household or on self medication.

Children. Table 3.1 presents information on the type of health personnel who assist children affected by diarrhea or respiratory infections. Overall, half of these children are treated by their fathers or other members of the household. The large majority of children in the lower consumption quintiles receive medication from non-medically qualified personnel. Only in the highest quintile do sick children have a higher probability of being seen by a doctor than by any other person. The incidence of non-indigenous children being treated by a doctor ( 32 percent) is almost twice as high as the incidence of indigenous children (18 percent). In urban areas, half of the children are taken either to a doctor or to other medically trained personnel. The corresponding figure is only 40 percent in rural areas. Only in the Metropolitan region are children assisted by doctors more than 50 percent of the number of times they are sick. 
Table 3.1: Treatment of Children with Diarrhea or Acute Respiratory Infections Percentage of Sick Children Assisted by Different Personnel

\begin{tabular}{|c|c|c|c|c|}
\hline & Non-medically trained & $\begin{array}{l}\text { Nurse or Promodor de } \\
\text { Salud }\end{array}$ & Doctor & $\begin{array}{c}\text { Father or Member of the } \\
\text { Household }\end{array}$ \\
\hline $\begin{array}{l}\text { Total } \\
\text { Consumption Quintile }\end{array}$ & 6.4 & 17.8 & 25.8 & 50.0 \\
\hline Q1 & 6.4 & 24.1 & 14.1 & 55.4 \\
\hline Q2 & 5.7 & 23.4 & 18.5 & 52.4 \\
\hline Q3 & 7.5 & 17.5 & 22.0 & 53.1 \\
\hline Q4 & 62 & 9.4 & 39.4 & 45.0 \\
\hline Q5 & 5.9 & 4.2 & 56.2 & 33.8 \\
\hline \multicolumn{5}{|l|}{ Poverty Status } \\
\hline Non Poor & 6.1 & 8.8 & 43.3 & 41.9 \\
\hline Poor & 6.5 & 22.3 & 17.1 & 54.1 \\
\hline Extremely Poor & 7.1 & 24.9 & 12.1 & 56.0 \\
\hline \multicolumn{5}{|l|}{ Ethnicity } \\
\hline Indigenous & 7.9 & 20.7 & 18.3 & 53.1 \\
\hline K'iche & 15.0 & 16.0 & 21.8 & 47.3 \\
\hline Q'ueqchı & 7.7 & 22.8 & 14.6 & 55.0 \\
\hline Kaqchiquel & 5.4 & 13.7 & 28.7 & 52.2 \\
\hline Mam & 6.1 & 24.3 & 10.4 & 59.2 \\
\hline Other Mayan & 5.9 & 26.4 & 15.8 & 52.0 \\
\hline Other Indigenous & 126 & 33.3 & 17.2 & 36.9 \\
\hline Non-indigenous & 4.9 & 15.2 & 32.7 & 47.2 \\
\hline \multicolumn{5}{|l|}{ Area } \\
\hline Urban & 6.3 & 7.8 & 44.6 & 41.3 \\
\hline Rural & 6.4 & 22.0 & 18.1 & 53.6 \\
\hline \multicolumn{5}{|l|}{ Region } \\
\hline Metropolitana & 5.2 & 2.8 & 54.3 & 37.8 \\
\hline Norte & 6.2 & 23.6 & 15.2 & 55.1 \\
\hline Nororiente & 6.4 & 206 & 28.7 & 44.3 \\
\hline Suroriente & 4.6 & 21.4 & 20.5 & 53.5 \\
\hline Central & 4.3 & 11.9 & 27.0 & 56.8 \\
\hline Suroccidente & 7.0 & 20.6 & 19.2 & 53.4 \\
\hline Noroccidente & 10.5 & 247 & 13.4 & 51.5 \\
\hline Peten & 4.5 & 29.6 & 17.8 & 48.1 \\
\hline
\end{tabular}

Source: World Bank calculations using the ENCOVI 2000, Instituto Nacional de Estadistica-Guatemala

One-half of all children with diarrhea or respiratory infections are treated inside their own homes rather than in any health facility (Table 3.2). The large majority of children who are taken to community centers are poor or extremely poor. Health centers and health posts are the health facilities that are most frequently used for children in the poorest quintiles (Q1, Q2, and Q3), while children in the highest consumption quintiles use mostly private hospitals and clinics. IGSS facilities are used only by 8 percent of non-poor children and by 15.7 percent of children living in the Metropolitan region. In the Norte and Nororiente regions, 7.2 percent and 8.7 percent of children respectively use community centers. 
Table 3.2: Type of Facility Visited by Children with Diarrhea or Acute Respiratory Infection -Percentage of Children Visiting Different Health Facilities

\begin{tabular}{|c|c|c|c|c|c|c|c|c|}
\hline & $\begin{array}{l}\text { Public } \\
\text { Hospital }\end{array}$ & $\begin{array}{c}\text { IGSS } \\
\text { Hospital }\end{array}$ & $\begin{array}{l}\text { Private } \\
\text { Hospital or } \\
\text { Clinic }\end{array}$ & $\begin{array}{l}\text { Health Post } \\
\text { or Health } \\
\text { Center }\end{array}$ & $\begin{array}{l}\text { Community } \\
\text { Center }\end{array}$ & Pharmacy & At Home & Other \\
\hline $\begin{array}{l}\text { Total } \\
\text { Consumption Quintile }\end{array}$ & 2.3 & 4.1 & 10.8 & 19.3 & 3.2 & 4.6 & 52.7 & 3.0 \\
\hline Q1 & 1.4 & 1.0 & 3.5 & 21.9 & 7.1 & 3.7 & 59.3 & 2.3 \\
\hline Q2 & 1.1 & 3.2 & 4.6 & 23.9 & 2.2 & 4.4 & 55.1 & 5.5 \\
\hline Q3 & 2.4 & 3.1 & 8.0 & 20.7 & 1.7 & 5.0 & 56.0 & 3.1 \\
\hline Q4 & 4.7 & 8.6 & 17.2 & 14.2 & 2.2 & 6.1 & 45.4 & 1.5 \\
\hline Q5 & 3.1 & 8.6 & 38.6 & 8.2 & 0.0 & 4.0 & 36.2 & 1.1 \\
\hline \multicolumn{9}{|l|}{ Poverty Status } \\
\hline Non Poor & 4.1 & 8.7 & 23.1 & 12.9 & 1.5 & 5.2 & 43.3 & 1.3 \\
\hline All Poor & 1.5 & 1.8 & 4.8 & 22.5 & 4.0 & 4.3 & 57.3 & 3.8 \\
\hline Extremely Poor & 1.1 & 0.9 & 3.1 & 21.9 & 6.8 & 4.0 & 60.1 & 2.3 \\
\hline \multicolumn{9}{|l|}{ Ethnicity } \\
\hline Indigenous & 1.7 & 2.9 & 6.6 & 20.5 & 4.0 & 5.6 & 55.7 & 3.1 \\
\hline K'iche & 1.9 & 4.0 & 9.8 & 18.8 & 2.6 & 13.2 & 48.0 & 1.8 \\
\hline Q'ueqchi & 1.6 & 0.3 & 4.2 & 16.1 & 8.5 & 6.3 & 59.2 & 3.8 \\
\hline Kaqchiquel & 1.3 & 7.6 & 8.6 & 22.3 & 1.1 & 1.1 & 55.1 & 3.0 \\
\hline Mam & 0.2 & - & 6.1 & 21.2 & 4.0 & 4.0 & 61.4 & 3.2 \\
\hline Other Mayan & 2.5 & 2.0 & 4.4 & 22.7 & 4.0 & 3.9 & 55.6 & 3.9 \\
\hline Other Indigenous & 4.7 & - & - & 33.3 & 12.5 & 12.6 & 36.9 & - \\
\hline Non-indigenous & 2.9 & 5.2 & 14.8 & 18.3 & 2.4 & 3.7 & 49.8 & 2.9 \\
\hline \multicolumn{9}{|l|}{ Area } \\
\hline Urban & 3.3 & 11.0 & 19.6 & 151 & 1.0 & 5.1 & 42.6 & 2.8 \\
\hline Rural & 19 & 1.3 & 7.3 & 21.1 & 4.2 & 4.4 & 56.8 & 3.1 \\
\hline \multicolumn{9}{|l|}{ Region } \\
\hline Metropolitana & 2.1 & 15.7 & 24.0 & 10.7 & 0.0 & 2.4 & 40.5 & 4.3 \\
\hline Norte & 2.0 & 0.0 & 4.1 & 21.3 & 7.2 & 4.2 & 58.0 & 3.0 \\
\hline Nororiente & 3.2 & 1.0 & 8.7 & 24.6 & 8.7 & 5.1 & 48.1 & 1.0 \\
\hline Suroriente & 3.3 & 1.0 & 8.0 & 19.9 & 2.0 & 3.1 & 57.1 & 5.8 \\
\hline Central & 3.4 & 4.2 & 10.1 & 17.3 & 2.1 & 3.1 & 58.2 & 1.7 \\
\hline Suroccidente & 1.1 & 2.7 & 9.7 & 21.8 & 2.7 & 6.1 & 54.4 & 1.6 \\
\hline Noroccidente & 3.1 & 0.0 & 7.3 & 20.7 & 2.6 & 7.5 & 55.3 & 3.5 \\
\hline Peten & 4.2 & 0.0 & 4.8 & 21.5 & 1.1 & 2.0 & 57.6 & 8.9 \\
\hline
\end{tabular}

Source. World Bank calculations using the ENCOVI 2000, Instituto Nacional de Estadistica - Guatemala

The Whole Population. Table 3.3 presents the proportion of the Guatemalan population who received either curative or preventive health care from different types of health personnel during the month before the interview. In contrast to the patterns observed for children, a large proportion of individuals (36 percent) is assisted by a doctor. Another large share of the population relies on self-medication or the assistance of other individuals within the household. The proportion of individuals who are treated by doctors varies significantly across consumption quintiles (13.6 percent among the poorest 20 percent of the population and almost 60 percent among the richest 20 percent of the population). Poor and extremely poor individuals often rely on treatment from other members of their households or on self-medication. One-fifth of extremely poor individuals do nothing to ameliorate their illnesses. There appears to be a significant difference in the behavior of individuals by ethnicity. Doctors treat 44 percent of nonindigenous people and only 24 percent of indigenous people. Indigenous people tend to rely more often than non-indigenous people on the help of other members of their households, on self-medication, and on 
non-medically trained practitioners.. In urban areas, more than half of the population sees a doctor. In rural areas, only a quarter of the population sees a doctor, while almost one-half of the population receive treatment within their households or rely on self-medication.

Table 3.3: Treatment of Individuals during the Month before the Interview Percentage of People Assisted by Different Personnel

\begin{tabular}{|c|c|c|c|c|c|c|}
\hline & $\begin{array}{l}\text { Non-medically } \\
\text { trained }\end{array}$ & $\begin{array}{l}\text { Nurse or } \\
\text { promodor de } \\
\text { salud }\end{array}$ & Doctor & $\begin{array}{l}\text { Relative or } \\
\text { Member of the } \\
\text { Household }\end{array}$ & $\begin{array}{c}\text { Self- } \\
\text { medication }\end{array}$ & Did Nothing \\
\hline $\begin{array}{l}\text { Total } \\
\text { Consumption Quintile }\end{array}$ & 4.8 & 9.5 & 36.1 & 19.2 & 19.5 & 10.9 \\
\hline Q1 & 4.5 & 16.5 & 13.6 & 29.8 & 17.2 & 18.4 \\
\hline Q2 & 4.9 & 13.9 & 22.6 & 23.0 & 25.0 & 10.7 \\
\hline Q3 & 6.6 & 11.8 & 32.6 & 21.0 & 18.3 & 9.7 \\
\hline Q4 & 5.4 & 7.8 & 39.0 & 17.2 & 21.5 & 9.1 \\
\hline Q5 & 3.3 & 2.3 & 58.1 & 11.0 & 16.8 & 8.6 \\
\hline \multicolumn{7}{|l|}{ Poverty Status } \\
\hline Non Poor & 4.4 & 53 & 49.0 & 14.0 & 18.6 & 8.7 \\
\hline All Poor & 5.3 & 14.0 & 22.2 & 24.9 & 20.5 & 13.2 \\
\hline Extremely Poor & 4.3 & 16.7 & 13.6 & 30.2 & 15.7 & 19.5 \\
\hline \multicolumn{7}{|l|}{ Ethnicity } \\
\hline Indigenous & 5.9 & 13.7 & 24.0 & 22.8 & 20.7 & 12.9 \\
\hline K'iche & 92 & 9.5 & 29.7 & 175 & 23.7 & 10.4 \\
\hline Q'ueqchı & 5.8 & 20.8 & 14.9 & 29.8 & 8.6 & 20.1 \\
\hline Kaqchiquel & 4.0 & 6.5 & 31.7 & 21.9 & 24.7 & 11.2 \\
\hline Mam & 3.5 & 17.7 & 18.0 & 20.9 & 31.0 & 8.9 \\
\hline Other Mayan & 6.0 & 15.3 & 23.1 & 26.4 & 14.5 & 14.7 \\
\hline Other Indigenous & 6.3 & 23.2 & 26.1 & 5.5 & 29.7 & 9.2 \\
\hline Non-indigenous & 4.1 & 6.6 & 44.4 & 16.8 & 18.8 & 9.4 \\
\hline \multicolumn{7}{|l|}{ Area } \\
\hline Urban & 3.6 & 3.6 & 51.8 & 14.7 & 17.8 & 8.6 \\
\hline Rural & 5.7 & 13.7 & 25.0 & 22.5 & 20.8 & 12.5 \\
\hline \multicolumn{7}{|l|}{ Region } \\
\hline Metropolitana & 2.1 & 1.7 & 52.9 & 12.6 & 21.1 & 9.6 \\
\hline Norte & 5.5 & 17.6 & 17.4 & 28.1 & 8.6 & 22.8 \\
\hline Nororiente & 6.2 & 11.8 & 33.8 & 25.3 & 13.4 & 9.5 \\
\hline Suroriente & 5.9 & 13.4 & 34.2 & 18.4 & 18.4 & 9.7 \\
\hline Central & 3.3 & 6.4 & 38.2 & 21.2 & 21.8 & 9.2 \\
\hline Suroccidente & 6.2 & 9.4 & 31.2 & 20.8 & 23.3 & 9.1 \\
\hline Noroccidente & 7.1 & 16.4 & 25.1 & 16.9 & 22.2 & 12.3 \\
\hline Peten & 4.3 & 22.7 & 31.3 & 20.4 & 11.7 & 9.6 \\
\hline
\end{tabular}

Source. World Bank calculations using the ENCOVI 2000, Instituto Nacional de Estadistica-Guatemala

Table 3.4 disaggregates the proportion of individuals visiting different health facilities by their consumption level, area, and region. Private structures, like hospitals and clinics, are the most frequently used facilities in Guatemala, followed by the health centers and health posts and then by public hospitals. About two-thirds of individuals in the top quintile use private hospitals and 9.3 percent go to IGSS facilities. The corresponding figures are only 12.6 percent and 2.2 percent for individuals in the bottom quintile, a large majority of whom use health centers and health posts (39.9 percent). Even in rural areas and among indigenous people, a significant proportion of the population uses private facilities (about 30 percent in both cases). In the Metropolitana, Nororiente, and Central regions, a large proportion of people 
uses private facilities. In most of the other regions, the health centers and health posts are the most frequently used health facilities.

Table 3.4: Type of Facility Visited by All Individuals during a Month Before the Interview - Percentage of People Visiting Different Health Facilities

\begin{tabular}{|c|c|c|c|c|c|c|c|c|}
\hline & $\begin{array}{l}\text { Public } \\
\text { Hospital }\end{array}$ & $\begin{array}{l}\text { IGSS } \\
\text { Hospital }\end{array}$ & $\begin{array}{l}\text { Private } \\
\text { Hospital or } \\
\text { Clinic }\end{array}$ & $\begin{array}{l}\text { Health Post } \\
\text { or Health } \\
\text { Center }\end{array}$ & $\begin{array}{l}\text { Community } \\
\text { Center }\end{array}$ & Pharmacy & House & Other \\
\hline $\begin{array}{l}\text { Total } \\
\text { Consumption Quintile }\end{array}$ & 9.3 & 6.8 & 40.0 & 22.8 & 2.0 & 8.0 & 5.5 & 5.7 \\
\hline QI & 8.5 & 2.2 & 12.6 & 39.9 & 5.4 & 8.1 & 8.2 & 15.1 \\
\hline Q2 & 10.8 & 3.2 & 24.8 & 35.5 & 2.1 & 9.2 & 7.1 & 7.3 \\
\hline Q3 & 10.2 & 5.7 & 26.9 & 34.3 & 2.2 & 10.3 & 4.0 & 6.4 \\
\hline Q4 & 11.8 & 8.2 & 39.6 & 23.2 & 1.7 & 9.0 & 2.0 & 4.4 \\
\hline Q5 & 6.8 & 9.3 & 62.5 & 5.7 & 0.9 & 5.5 & 6.9 & 2.5 \\
\hline \multicolumn{9}{|l|}{ Poverty Status } \\
\hline Non Poor & 8.9 & 8.5 & 52.2 & 13.7 & 1.3 & 7.0 & 5.0 & 3.5 \\
\hline All Poor & 9.9 & 4.1 & 21.5 & 36.8 & 3.0 & 9.4 & 6.2 & 9.2 \\
\hline Extremely Poor & 7.5 & 2.5 & 12.6 & 38.8 & 5.9 & 7.6 & 8.6 & 16.6 \\
\hline \multicolumn{9}{|l|}{ Ethnicity } \\
\hline Indigenous & 8.1 & 3.7 & 30.2 & 29.6 & 3.2 & 11.5 & 6.5 & 7.3 \\
\hline K'iche & 7.9 & 7.9 & 32.5 & 27.5 & 1.5 & 19.0 & 1.4 & 2.3 \\
\hline Q'ueqchi & 6.7 & 1.0 & 20.6 & 23.5 & 5.3 & 9.5 & 13.2 & 20.1 \\
\hline Kaqchiquel & 4.5 & 4.4 & 48.0 & 24.0 & 4.0 & 7.3 & 5.0 & 2.7 \\
\hline Mam & 8.0 & 0.1 & 26.0 & 36.6 & 5.5 & 7.4 & 8.1 & 8.3 \\
\hline Other Mayan & 13.7 & 2.6 & 20.0 & 38.2 & 0.9 & 11.4 & 7.2 & 6.1 \\
\hline Other Indigenous & 11.5 & 5.0 & 19.0 & 53.2 & - & 3.3 & 8.0 & - \\
\hline Non-Indigenous & 9.9 & 8.4 & 45.4 & 19.1 & 1.3 & 6.0 & 4.9 & 4.8 \\
\hline \multicolumn{9}{|l|}{ Area } \\
\hline Urban & 8.8 & 10.5 & 51.5 & 13.8 & 0.8 & 5.6 & 5.2 & 3.9 \\
\hline Rural & 9.7 & 3.2 & 29.3 & 31.4 & 3.1 & 10.2 & 5.7 & 7.5 \\
\hline \multicolumn{9}{|l|}{ Region } \\
\hline Metropolitana & 5.2 & 13.4 & 54.3 & 11.3 & 0.6 & 4.3 & 5.9 & 5.2 \\
\hline Norte & 12.9 & 1.6 & 17.2 & 30.6 & 5.2 & 9.9 & 8.9 & 13.9 \\
\hline Nororiente & 11.8 & 2.8 & 39.0 & 26.2 & 1.0 & 9.5 & 4.6 & 5.3 \\
\hline Suroriente & 11.8 & 3.1 & 29.7 & 32.2 & 3.2 & 4.7 & 4.4 & 10.9 \\
\hline Central & 11.6 & 11.2 & 43.7 & 17.8 & 3.1 & 4.9 & 4.8 & 3.0 \\
\hline Suroccidente & 9.1 & 4.7 & 37.7 & 27.3 & 2.4 & 12.8 & 3.8 & 2.3 \\
\hline Noroccidente & 10.3 & 0.6 & 31.0 & 31.7 & 2.0 & 11.5 & 6.7 & 6.2 \\
\hline Peten & 14.8 & 0.3 & 26.1 & 30.5 & 1.3 & 4.3 & 10.1 & 12.6 \\
\hline
\end{tabular}

Source: World Bank calculations using the ENCOVI 2000, Instituto Nacional de Estadistica - Guatemala

Pregnant Women. The type and quality of prenatal care that a woman receives during her pregnancy and delivery are very important factors for her health and the health of her children. Therefore, these aspects of health care are important elements in evaluating the health conditions of any given country.

Table 3.5 displays information on prenatal visits in Guatemala. Almost 80 percent of women with children made at least one prenatal visit in Guatemala, a proportion that reaches almost 90 percent among women in the highest consumption quintile and falls to 66 percent among women in the lowest consumption quintile, and to 64 percent among extremely poor mothers. More than a quarter of women in 
rural areas (27 percent) had no prenatal care at all, compared to half of that percentage in urban areas (13 percent). Even higher percentages of women than in rural areas in general have received no prenatal care in the Noroccidente, Suroccidente, and Norte regions.

Overall, most prenatal visits are carried out by doctors with the rest mostly being carried out by traditional midwives (comadromas). A low proportion of the population is visited by nurses or non-medically trained personnel ( 11 percent and 2 percent). However, there is an important difference between the poor and the non-poor. Almost 90 percent of the richest women receive assistance from doctors, while the corresponding figure is only 20 percent among the poorest women who, in the majority of the cases, are attended by midwives. In urban areas, twice as many women are visited by a doctor as in rural areas ( 78 percent vs. 35 percent). The same pattern is observed among indigenous and non-indigenous women. Moreover, the percentage of indigenous women who see a midwife is more than double the percentage of non-indigenous women. In the Metropolitan region, 94 percent of women are assisted by doctors. 
Table 3.5: Patterns of Prenatal Visits and Treatment of Pregnant Women

\begin{tabular}{|c|c|c|c|c|c|c|c|}
\hline & \multicolumn{2}{|c|}{$\begin{array}{l}\text { Had Prenatal Checks } \\
\text { ( } \% \text { of Non-Pregnant) }\end{array}$} & \multicolumn{5}{|c|}{$\begin{array}{l}\text { Who Did the Checks } \\
\text { (Percentage of Women Who Had Prenatal Checks) }\end{array}$} \\
\hline & Never & Yes & $\begin{array}{l}\text { Non-Medically } \\
\text { Trained }\end{array}$ & Midwife & $\begin{array}{l}\text { Nurse or } \\
\text { Promotor }\end{array}$ & Doctor & $\begin{array}{l}\text { Father or other family } \\
\text { member }\end{array}$ \\
\hline $\begin{array}{l}\text { Total } \\
\text { Consumption Quintile }\end{array}$ & 21.3 & 75.6 & 2.4 & 33.7 & 11.0 & 52.4 & 0.6 \\
\hline Q1 & 34.2 & 65.8 & 4.4 & 59.7 & 15.7 & 19.5 & 0.7 \\
\hline Q2 & 28.0 & 72.0 & 2.6 & 45.4 & 15.6 & 36.2 & 0.2 \\
\hline Q3 & 22.7 & 77.3 & 1.8 & 36.3 & 12 & 49.3 & 0.6 \\
\hline Q4 & 10.2 & 89.8 & 1.3 & 20.3 & 8.6 & 69.8 & 0.9 \\
\hline Q5 & 8.8 & 91.2 & 2.0 & 6.1 & 2.5 & 89.1 & 0.2 \\
\hline \multicolumn{8}{|l|}{ Poverty Status } \\
\hline Non Poor & 11.1 & 89.0 & 1.6 & 16.1 & 6.3 & 75.5 & 0.6 \\
\hline Poor & 28.9 & 71.1 & 3.0 & 478 & 14.8 & 33.9 & 0.5 \\
\hline Extremely Poor & 35.9 & 64.1 & 4.8 & 61.1 & 14.7 & 18.6 & 1.0 \\
\hline \multicolumn{8}{|l|}{ Ethnicity } \\
\hline Indigenous & 26.2 & 69.8 & 4.2 & 49.2 & 12.7 & 32.9 & 10 \\
\hline K'iche & 17.3 & 77.6 & 3.2 & 49.7 & 9.3 & 37.1 & 0.7 \\
\hline Q'ueqchi & 26.6 & 69.0 & 10.3 & 33.2 & 26.1 & 29.8 & 0.6 \\
\hline Kaqchiquel & 11.0 & 82.8 & 1.2 & 47.0 & 8.0 & 43.7 & - \\
\hline Mam & 35.1 & 62.7 & 4.9 & 59.5 & 10.3 & 23.0 & 2.4 \\
\hline Other Mayan & 40.6 & 57.2 & 3.6 & 56.9 & 13.3 & 24.4 & 1.9 \\
\hline Other Indigenous & 46 & 81.1 & 0.0 & 5.5 & 43.6 & 51.0 & - \\
\hline Non-indigenous & 17.3 & 80.3 & 1.1 & 22.7 & 9.8 & 66.2 & 0.2 \\
\hline \multicolumn{8}{|l|}{ Area } \\
\hline Urban & 13.3 & 86.7 & 1.4 & 14.4 & 5.4 & 78.4 & 0.4 \\
\hline Rural & 26.8 & 73.2 & 3.0 & 46.7 & 14.8 & 34.9 & 0.7 \\
\hline \multicolumn{8}{|l|}{ Region } \\
\hline Metropolitana & 9.0 & 91.1 & 2.4 & 7.2 & 2.1 & 88.0 & 0.4 \\
\hline Norte & 27.9 & 72.1 & 7 & 23.8 & 30.8 & 38.0 & 0.4 \\
\hline Nororiente & 24.9 & 75.1 & 3.3 & 21.3 & 14.9 & 60.4 & 0.0 \\
\hline Suroriente & 16.6 & 83.4 & 0.8 & 40.4 & 13.7 & 45.1 & 0.0 \\
\hline Central & 10.8 & 89.2 & 0.5 & 35.4 & 8.4 & 55.3 & 0.3 \\
\hline Suroccidente & 27.1 & 72.9 & 1.4 & 44 & 10.9 & 42.9 & 0.8 \\
\hline Noroccidente & 35.5 & 64.5 & 4.0 & 61.1 & 10.7 & 22.8 & 1.4 \\
\hline Peten & 19.1 & 80.9 & 2.5 & 51.7 & 14.3 & 30.8 & 0.7 \\
\hline
\end{tabular}

Note:Pregnant Women are excluded in order to avoid censoring.

Source. World Bank calculations using the ENCOVI 2000, Instituto Nacional de Estadistica-Guatemala

Table 3.6 presents the location of prenatal checks by different groups of women. In general, there appears to be no preferred facility. Almost half of the women in the top quintile receive assistance in private hospitals, while half of the women in the bottom quintile are assisted in their own house. One-fifth of the richest women go to IGSS hospitals. The proportion of indigenous women who receive prenatal care in their own house ( 66 percent) is more twice as high as the corresponding figure among non-indigenous women (33 percent). 
Table 3.6: Location of Prenatal Visits - Percentage of Women Who Had Prenatal Checks

\begin{tabular}{|c|c|c|c|c|c|c|c|c|}
\hline & $\begin{array}{l}\text { Public } \\
\text { Hospital }\end{array}$ & $\begin{array}{c}\text { IGSS } \\
\text { Hospital }\end{array}$ & $\begin{array}{l}\text { Private } \\
\text { Hospital or } \\
\text { Clinic }\end{array}$ & $\begin{array}{l}\text { Health Post } \\
\text { or Health } \\
\text { Center }\end{array}$ & Pharmacy & $\begin{array}{l}\text { Midwife's } \\
\text { House }\end{array}$ & Own House & Other \\
\hline $\begin{array}{l}\text { Total } \\
\text { Consumption Quintile }\end{array}$ & 12.5 & 9.3 & 17.0 & $\cdot 24.3$ & 0.2 & 13.5 & 21.8 & 1.6 \\
\hline Q1 & 3.9 & 1.2 & 2.0 & 25.5 & 0.0 & 18.7 & 45.6 & 31 \\
\hline Q2 & 9.7 & 4.1 & 4.4 & 31.8 & 0.2 & 16.9 & 31.3 & 1.5 \\
\hline Q3 & 156 & 7.4 & 8.1 & 31.6 & 0.6 & 17.3 & 18.4 & 1.1 \\
\hline Q4 & 192 & 13.5 & 24.0 & 21.5 & 0.0 & 11.0 & 9.2 & 1.6 \\
\hline Q5 & 12.9 & 20.9 & 48.7 & 9.6 & 0.0 & 2.6 & 4.8 & 0.6 \\
\hline \multicolumn{9}{|l|}{ Poverty Status } \\
\hline Non Poor & 16.7 & 16.4 & 32.3 & 17.0 & 0.1 & 8.7 & 7.7 & 1.1 \\
\hline All Poor & 91 & 3.6 & 4.7 & 30.1 & 0.2 & 17.3 & 33.0 & 2.1 \\
\hline Extremely Poor & 3.4 & 1.0 & 1.3 & 25.8 & 0.0 & 17.7 & 48.8 & 2.1 \\
\hline \multicolumn{9}{|l|}{ Ethnicity } \\
\hline Indigenous & 66 & 4.3 & 9.4 & 24.2 & 0.4 & 17.2 & 35.8 & 2.1 \\
\hline K'iche & 9.4 & 4.1 & 13.4 & 20.0 & - & 16.7 & 35.8 & 06 \\
\hline Q'ueqch1 & 8.5 & - & 9.8 & 31.3 & 2.3 & 15.3 & 26.0 & 6.6 \\
\hline Kaqchıquel & 6.1 & 10.0 & 10.4 & 23.6 & 01 & 16.5 & 31.1 & 2.0 \\
\hline Mam & 6.4 & 0.4 & 3.4 & 22.0 & - & 18.6 & 48.1 & 1.0 \\
\hline Other Mayan & 2.1 & 3.7 & 7.5 & 25.6 & - & 19.6 & 39.9 & 1.6 \\
\hline Other Indigenous & 9.3 & - & 33.0 & 52.3 & - & 5.5 & 0.0 & 0.0 \\
\hline Non-indigenous & 166 & 128 & 22.3 & 24.3 & - & 10.8 & 11.9 & 1.3 \\
\hline \multicolumn{9}{|l|}{ Area } \\
\hline Urban & 16.0 & 18.0 & 30.9 & 19.1 & 0.0 & 7.0 & 7.8 & 1.4 \\
\hline Rural & 10.1 & 35 & 7.6 & 278 & 0.3 & 17.8 & 31.2 & 1.8 \\
\hline \multicolumn{9}{|l|}{ Region } \\
\hline Metropolitana & 14.5 & 26.5 & 34.1 & 15.5 & 0.0 & 51 & 3.8 & 0.6 \\
\hline Norte & 14.3 & 1.1 & 22.6 & 37.5 & 0.8 & 3.9 & 17.1 & 2.8 \\
\hline Nororiente & $15.5^{-}$ & 3.8 & 33.8 & 30.5 & 0.0 & 8.5 & 6.1 & 1.9 \\
\hline Suroriente & 13.5 & 5.3 & 15.3 & 31.4 & 0.0 & 17.0 & 16.1 & 1.5 \\
\hline Central & 11.2 & 16.0 & 12.1 & 20.6 . & 0.2 & 18.3 & 18.5 & 3.0 \\
\hline Suroccidente & 12.9 & 3.0 & 19.1 & 24.9 & 0.0 & 12.9 & 26.5 & 0.7 \\
\hline Noroccidente & 6.5 & 0.8 & 13.2 & 19.9 & 0.0 & 17.0 & 41.8 & 0.8 \\
\hline Peten & 18.0 & 0.4 & 135 & 19.4 & 0.0 & 33.9 & 14.5 & 0.4 \\
\hline
\end{tabular}

Source: World Bank calculations using the ENCOVI 2000, Instituto Nacional de Estadistica - Guatemala

Almost 80 percent of Guatemalan women had normal births without complications (Table 4.7). Women in the lowest consumption quintile and women in rural areas tend to experience more complications during delivery. Women in the highest consumption quintile and women in urban areas had more cesarean deliveries ( 23 percent and 17 percent respectively). Both indigenous and non-indigenous women had normal deliveries without complications in 80 percent of the cases. The difference arises in the remaining 20 percent of deliveries; while non-indigenous women tend to have more cesarean deliveries, indigenous people more often have normal deliveries with complications. The Norte and Noroccidente regions recorded the highest proportion of complications during normal births and, at the same time, the lowest proportion of cesareans. 
Table 3.7 Type of Delivery - Percentage of Women who Delivered Babies (Last Pregnancy)

\begin{tabular}{|c|c|c|c|}
\hline & $\begin{array}{l}\text { Normal Delivery w/o } \\
\text { complications }\end{array}$ & $\begin{array}{l}\text { Normal Delivery with } \\
\text { complications }\end{array}$ & Cesarean \\
\hline $\begin{array}{l}\text { Total } \\
\text { Consumption Quintile }\end{array}$ & 79.9 & 10.5 & 9.6 \\
\hline Q1 & 81.6 & 16.6 & 1.8 \\
\hline Q2 & 83.0 & 10.5 & 6.5 \\
\hline Q3 & 84.2 & 8.6 & 7.3 \\
\hline Q4 & 78.7 & 8.5 & 12.8 \\
\hline Q5 & 69.2 & 7.4 & 23.4 \\
\hline \multicolumn{4}{|l|}{ Poverty Status } \\
\hline Non Poor & 74.4 & 9.0 & 16.7 \\
\hline All Poor & 83.5 & 11.5 & 4.9 \\
\hline Extremely Poor & 81.6 & 16.4 & 2.0 \\
\hline \multicolumn{4}{|l|}{ Ethnicity } \\
\hline Indigenous & 81.2 & 13.6 & 5.3 \\
\hline$K^{\prime} i c h e$ & 82.1 & 10.7 & 7.2 \\
\hline Q'ueqchi & 74.3 & 22.0 & 3.7 \\
\hline Kaqchıquel & 80.6 & 10.3 & 9.1 \\
\hline Mam & 79.1 & 16.4 & 4.5 \\
\hline Other Mayan & 88.5 & 10.8 & 0.7 \\
\hline Other Indigenous & 72.3 & 16.0 & 11.7 \\
\hline Non-indigenous & 79.0 & 8.2 & 12.9 \\
\hline \multicolumn{4}{|l|}{ Area } \\
\hline Urban & 76.3 & 7.2 & 16.6 \\
\hline Rural & 82.1 & 12.5 & 5.4 \\
\hline \multicolumn{4}{|l|}{ Region } \\
\hline Metropolitana & 76.6 & 6.4 & 16.9 \\
\hline Norte & 74.5 & 23.0 & 2.6 \\
\hline Noronente & 78.0 & 10.4 & 11.6 \\
\hline Suroriente & 85.7 & 7.1 & 7.2 \\
\hline Central & 81.1 & 8.9 & 10.1 \\
\hline Suroccidente & 79.7 & 9.8 & 10.5 \\
\hline Noroccidente & 82.7 & 14.9 & 2.4 \\
\hline Peten & 88.5 & 6.2 & 5.4 \\
\hline
\end{tabular}

Table 3.8 presents the distribution of births by the type of medical staff who assisted the woman during her delivery. Overall, traditional midwives attend almost half of all births, doctors attend 40 percent, other members of the families 5.6 percent, and nurses 4.5 percent. A large majority ( 71 percent) of poor women are assisted by midwives during delivery, while most rich women are assisted by doctors ( 83 percent). Almost all of the richer women are attended by an individual with some kind of medical training (such as doctors, nurses, or midwives). The poorest women, on the other hand, are helped by people who have no medical training, including members of their own households, in 15 percent of cases. The same pattern is observed between indigenous and non-indigenous women. Four-fifths of women in the Metropolitan region have their babies delivered by doctors, while more than a quarter of women in the Norte region are assisted by members of their households. 
Table 3.8: Treatment during Delivery - Percentage of Women who Delivered Babies (Last Pregnancy)

\begin{tabular}{|c|c|c|c|c|c|}
\hline & \multicolumn{5}{|c|}{ Who assisted during birth } \\
\hline & $\begin{array}{l}\text { Non Medically } \\
\text { Trained }\end{array}$ & Midwife & $\begin{array}{l}\text { Nurse or } \\
\text { Promotor }\end{array}$ & Doctor & $\begin{array}{c}\text { Father or other family } \\
\text { member }\end{array}$ \\
\hline $\begin{array}{l}\text { Total } \\
\text { Consumption Quintile }\end{array}$ & 2.7 & 47.1 & 4.5 & 40.1 & 5.6 \\
\hline Q1 & 4.1 & 70.5 & 3.1 & 11.0 & 11.3 \\
\hline Q2 & 2.5 & 63.1 & 4.8 & 21.5 & 8.2 \\
\hline Q3 & 3.4 & 49.4 & 4.5 & 36.6 & 6.1 \\
\hline Q4 & 2.2 & 29.8 & 6.1 & 61.2 & 0.7 \\
\hline Q5 & 0.9 & 12.3 & 3.9 & 83.0 & 0.0 \\
\hline \multicolumn{6}{|l|}{ Poverty Status } \\
\hline Non Poor & 1.7 & 24.6 & 4.9 & 67.9 & 0.9 \\
\hline All Poor & 3.4 & 62.0 & 4.2 & 21.7 & 8.7 \\
\hline Extremely Poor & 4.4 & 71.9 & 2.4 & 10.0 & 11.3 \\
\hline \multicolumn{6}{|l|}{ Ethnicity } \\
\hline Indigenous & 3.4 & 63.1 & 3.4 & 19.9 & 10.2 \\
\hline K'iche & 4.3 & 66.5 & 1.1 & 27.5 & 0.5 \\
\hline Q'ueqchı & 3.9 & 35.8 & 8.5 & 13.9 & 37.5 \\
\hline Kaqchiquel & 0.1 & 65.8 & 3.3 & 30.0 & 0.5 \\
\hline Mam & 5.3 & 63.5 & 2.2 & 14.0 & 14.3 \\
\hline Other Mayan & 2.0 & 77.4 & 3.4 & 11.6 & 5.7 \\
\hline Other Indigenous & 0.0 & 27.4 & 6.1 & 57.4 & 0.0 \\
\hline Non-indigenous & 2.2 & 34.8 & 5.3 & 55.6 & 2.1 \\
\hline \multicolumn{6}{|l|}{ Area } \\
\hline Urban & 2.4 & 25.0 & 4.3 & 67.6 & 0.7 \\
\hline Rural & 2.9 & 60.2 & 4.6 & 23.8 & 8.5 \\
\hline \multicolumn{6}{|l|}{ Region } \\
\hline Metropolitana & 3.2 & 15.5 & 0.7 & 80.5 & 0.1 \\
\hline Norte & 1.6 & 42.9 & 9.7 & 18.8 & 27.0 \\
\hline Nororiente & 2.8 & 29.5 & 15.3 & 44.0 & 8.4 \\
\hline Suroriente & 3.6 & 59.0 & 4.3 & 31.3 & 1.8 \\
\hline Central & 0.9 & 51.6 & 5.2 & 42.0 & 0.3 \\
\hline Suroccidente & 2.3 & 54.1 & 2.5 & 34.8 & 6.3 \\
\hline Noroccidente & 3.7 & 75.6 & 2.2 & 15.1 & 3.4 \\
\hline Peten & 5.5 & 60.2 & 8.1 & 19.3 & 6.9 \\
\hline
\end{tabular}

Source: World Bank calculations using the ENCOVI 2000, Instituto Nacional de Estadística - Guatemala

Table 3.9 shows the distribution of deliveries by the kind of health facility at which they take place. Over half of all babies are delivered in the mother's own home. Public hospitals are the second most frequently used place for delivery. The majority of the remaining births take place in private hospitals and clinics and in IGSS hospitals (about 8 percent for both types of facilities). Women in the higher consumption quintiles tend to use hospitals (public, private, or IGSS), while more than 80 percent of the poorest women deliver their babies in their own homes. Most indigenous, poor, and rural women (70 percent) deliver their babies in their own homes. Extremely poor women do so in 86 percent of the cases. On the contrary, non-indigenous and non-poor women prefer to use one of the hospitals (public, private or IGSS). In the Noroccidente and Norte regions, the majority of children (80.8 percent and 72.5 percent) are born in their mothers' homes. 
Table 3.9: Place of Delivery - Percentage of Women who Delivered Babies

(Last Pregnancy)

\begin{tabular}{|c|c|c|c|c|c|c|c|}
\hline & $\begin{array}{l}\text { Public } \\
\text { Hospital }\end{array}$ & $\begin{array}{l}\text { IGSS } \\
\text { Hospital }\end{array}$ & $\begin{array}{c}\text { Private } \\
\text { Hospital or } \\
\text { Clinic }\end{array}$ & $\begin{array}{l}\text { Health Post } \\
\text { or Health } \\
\text { Center }\end{array}$ & $\begin{array}{l}\text { Midwife's } \\
\text { House }\end{array}$ & Own House & Other \\
\hline $\begin{array}{l}\text { Total } \\
\text { Consumption Quintile }\end{array}$ & 25.7 & 7.6 & 8.0 & 3.3 & 3.1 & 51.8 & 0.5 \\
\hline Q1 & 9.8 & 1.3 & 0.1 & 1.5 & 3.4 & 83.5 & 0.4 \\
\hline Q2 & 18.3 & 3.4 & 0.7 & 3.3 & 2.9 & 70.5 & 0.8 \\
\hline Q3 & 30.0 & 4.7 & 2.5 & 4.9 & 4.7 & 52.3 & 0.9 \\
\hline Q4 & 41.2 & 12.7 & 11.7 & 3.4 & 2.9 & 28.2 & 0.0 \\
\hline Q5 & 32.1 & 19.5 & 31.4 & 3.8 & 1.2 & 11.9 & 0.3 \\
\hline \multicolumn{8}{|l|}{ Poverty Status } \\
\hline Non Poor & 37.6 & 14.6 & 18.3 & 3.4 & 2.2 & 23.8 & 0.1 \\
\hline All Poor & 17.9 & 3.0 & 1.2 & 3.3 & 3.7 & 70.2 & 0.7 \\
\hline Extremely Poor & 9.3 & 0.9 & 0.0 & 1.2 & 2.5 & 85.8 & 0.5 \\
\hline \multicolumn{8}{|l|}{ Ethnicity } \\
\hline Indigenous & 13.6 & 3.5 & 3.2 & 1.8 & 3.2 & 74.5 & 0.2 \\
\hline K'iche & 19.8 & 4.2 & 4.7 & 0.1 & 5.1 & 65.8 & 0.4 \\
\hline Q'ueqchi & 14.9 & 0.0 & 1.7 & 2.4 & 1.2 & 79.2 & 0.5 \\
\hline Kaqchiquel & 15.5 & 6.9 & 7.2 & 1.9 & 2.1 & 66.5 & 0.0 \\
\hline Mam & 11.6 & 1.6 & 1.0 & 0.8 & 4.5 & 80.6 & 0.0 \\
\hline Other Mayan & 5.9 & 3.3 & 1.3 & 3.9 & 2.6 & 82.9 & 0.1 \\
\hline Other Indigenous & 50.5 & 0.0 & 6.8 & 6.1 & 0.0 & 27.4 & 9.1 \\
\hline Non-indigenous & 35.1 & 10.8 & 11.6 & 4.5 & 3.1 & 34.2 & 0.7 \\
\hline \multicolumn{8}{|l|}{ Area } \\
\hline Urban & 35.4 & 15.8 & 16.9 & 4.0 & 2.3 & 25.2 & 0.4 \\
\hline Rural & 20.0 & 2.8 & 2.7 & 3.0 & 3.6 & 67.4 & 0.6 \\
\hline \multicolumn{8}{|l|}{ Region } \\
\hline Metropolitana & 29.8 & 29.4 & 19.3 & 4.3 & 1.0 & 15.8 & 0.5 \\
\hline Norte & 19.4 & 1.1 & 2.1 & 3.1 & 1.4 & 72.5 & 0.4 \\
\hline Nororiente & 38.8 & 1.4 & 10.9 & 9.3 & 1.0 & 37.2 & 1.3 \\
\hline Suroriente & 25.0 & 2.1 & 3.6 & 4.8 & 7.6 & 55.9 & 0.9 \\
\hline Central & 29.4 & 9.8 & 6.4 & 0.9 & 4.3 & 48.5 & 0.8 \\
\hline Suroccidente & 27.7 & 2.1 & 5.9 & 2.2 & 4.0 & 58.1 & 0.1 \\
\hline Noroccidente & 9.3 & 1.0 & 3.7 & 1.9 & 2.8 & 80.8 & 0.4 \\
\hline Peten & 22.0 & 0.5 & 3.2 & 2.3 & 3.3 & 68.8 & 0.0 \\
\hline
\end{tabular}

Source: World Bank calculations using the ENCOVT 2000, Instituto Nacional de Estadistica - Guatemala

Tables 3.10 and 3.11 give information on the average cost of prenatal visits. Only 21 percent of the mothers who were interviewed paid for their prenatal checks. On average, the traditional midwife charges less per visit than any other health practitioner. Even family members seem to charge more.

Table 3.10: Average Cost of Prenatal Visits by Type of Personnel

\begin{tabular}{l|ccccc}
\hline Quetzales & $\begin{array}{c}\text { Non Medically } \\
\text { Trained }\end{array}$ & Midwife & Nurse & Doctor & $\begin{array}{c}\text { Father or other } \\
\text { family member }\end{array}$ \\
\hline Total & 353 & 103 & 245 & 431 & 177 \\
Urban Areas & 1064 & 253 & 263 & 557 & 281 \\
Rural Areas & 213 & 81 & 235 & 222 & 84 \\
\hline
\end{tabular}

Source: World Bank calculations using the ENCOVI 2000, Instituto Nacional de Estadística - Guatemala 
Having a prenatal check in a private hospital is the most expensive option for women; the average cost is about 750 Quetzals in urban areas and 350 Quetzals in rural areas. The cheapest alternative is to have the check performed at home, often with the help of a traditional midwife or family members. IGSS hospitals and the house of the midwife are other affordable locations.

Table 3.11: Average Cost of Prenatal Visits by Type of Health Facility

\begin{tabular}{l|cccccccc}
\hline & $\begin{array}{c}\text { Public } \\
\text { Quspital }\end{array}$ & $\begin{array}{c}\text { IGSS } \\
\text { Hospital }\end{array}$ & $\begin{array}{c}\text { Private } \\
\text { Hospital or } \\
\text { Clinic }\end{array}$ & $\begin{array}{c}\text { Health Post } \\
\text { or Health }\end{array}$ & Pharmacy & $\begin{array}{c}\text { Midwife's } \\
\text { House }\end{array}$ & Own House & Other \\
\hline Total & 304 & 168 & 635 & 262 & 120 & 130 & 89 & 130 \\
Urban Areas & 407 & 183 & 747 & 394 & n'a & 252 & 334 & 446 \\
Rural Areas & 231 & 87 & 354 & 163 & 120 & 102 & 62 & 50 \\
\hline
\end{tabular}

Source: World Bank calculations using the ENCOVI 2000, Instituto Nacional de Estadistica - Guatemala

Table 3.12 displays information on the average cost of deliveries. One-fifth of mothers paid for their delivery. Delivering babies with the help of a doctor is the most expensive alternative at the national level, although in rural areas nurses tend to charge more than doctors. The assistance of the father or other family members is the cheapest alternative, followed by assistance from a traditional midwife.

Table 3.12: Average Cost of Giving Birth by Type of Personnel

\begin{tabular}{l|ccccc}
\hline & $\begin{array}{c}\text { Non Medically } \\
\text { Trained }\end{array}$ & Midwife & Nurse & Doctor & $\begin{array}{c}\text { Father or other family } \\
\text { member }\end{array}$ \\
Quetzales & 46 & 114 & 413 & 1864 & 77 \\
Total & n/a & 127 & 334 & 2641 & 40 \\
Urban Areas & 46 & 112 & 671 & 396 & 79 \\
\hline Rural Areas &
\end{tabular}

Source: World Bank calculations using the ENCOVT 2000, Instituto Nacional de Estadística-Guatemala

Delivering babies in private hospitals is the most expensive alternative (Table 3.13). The cheapest option is to deliver a baby at home. For women living in rural areas, it is cheaper to deliver their babies in public hospitals than in a midwife's house. Moreover, the long distances to public hospitals, as shown in Table 3.19 , often prevents pregnant women in rural areas from traveling there to deliver their babies.

Table 3.13: Average Cost of Giving Birth by Type of Health Facility

\begin{tabular}{l|ccccccc}
\hline & $\begin{array}{c}\text { Public } \\
\text { Hospital }\end{array}$ & $\begin{array}{c}\text { IGSS } \\
\text { Hospital }\end{array}$ & $\begin{array}{c}\text { Private } \\
\text { Hospital or } \\
\text { Clinic }\end{array}$ & $\begin{array}{c}\text { Health Post } \\
\text { or Health } \\
\text { Center }\end{array}$ & $\begin{array}{c}\text { Midwife's } \\
\text { House }\end{array}$ & Own House & Other \\
\hline Total & 274 & 500 & 3014 & 1262 & 224 & 105 & 120 \\
Urban Areas & 349 & 500 & 3471 & 1927 & 161 & 126 & n/a \\
Rurai Areas & 218 & n/a & 956 & 120 & 250 & 100 & 120 \\
\hline
\end{tabular}

Source- World Bank calculations using the ENCOVI 2000, Instituto Nacional de Estadistica - Guatemala

\section{Reasons for Not Seeking Treatment}

Previous research in the departments of Solola, Totonicapan, and San Marcos, areas that are generally considered to be underserved by the public health system, suggests that low utilization rates are only partly due to the physical inaccessibility of health facilities. ${ }^{57}$ Perhaps more important than the mere

${ }^{57}$ Annis (1981). 
physical availability and cost of the health facilities are their condition and the quality of the services that they offer.

Poor conditions and a lack of equipment were common complaints in a number of anthropological studies that asked clients and potential clients what they found most unsatisfactory about the way in which public health services are organized. ${ }^{58}$ Other complaints were: (i) a lack of medicine, which means that patients have to fill their prescriptions at pharmacies; (ii) the practice of conducting prenatal clinics, immunizations, and consultations all at different times, which is inconvenient for mothers with many children who require different kinds of medical attention; (iii) poor interaction between patients and health care personnel; and (iv) a lack of personnel and the rapid rotation of staff, which makes it difficult for a client to establish a rapport with any one provider. The Qualitative and Poverty Exclusion Study found that the most important reasons for not seeking treatment were: (i) the high cost of visits to health providers;(ii) a lack of transportation to other villages' health facilities; and (iii) discrimination due to the respondents' indigenous ethnicity or inability to speak Spanish.

The ENCOVI/INE 2000 data indicate that in the majority of cases people do not seek health care treatment because they believe that their sickness or accident is not important enough to need specialized attention (Tables 3.14a, 3.14b, and 3.14c). The second most important reason for not seeking treatment is due to financial issues; people report that they do not have enough money to afford the visit. This is the case more frequently among the poorest three quintiles and in rural areas (about 30 percent), while there is no big difference between indigenous and non-indigenous people. The long distances to health facilities are another important reason why people in rural areas and the very poor do not seek health care ( 9 percent and 12 percent respectively).

Table 3.14a: Reasons for Not Seeking Treatment by Area

\begin{tabular}{l|ccc}
\hline $\begin{array}{l}\text { Percentage of Those who were Ill } \\
\text { but did not seek Treatment }\end{array}$ & Total & Urban Area & Rural Area \\
\hline Not important & 51.1 & 64.4 & 44.4 \\
Did not have time & 3.6 & 4.3 & 3.2 \\
Health facility too far & 6.2 & 0.4 & 9.2 \\
Not enough money for transport & 2.8 & 1.5 & 3.4 \\
Not enough money for visit & 26.4 & 19.5 & 30.0 \\
Service too expensive & 2.8 & 2.4 & 3.1 \\
Lack of transportation & 0.4 & 0.0 & 0.6 \\
Don't trust the person & 1.1 & 1.3 & 0.9 \\
Lack of doctors/nurses & 1.6 & 0.4 & 2.2 \\
Don't speak my language & 0.5 & 0.2 & 0.7 \\
Waiting time too long & 0.7 & 0.4 & 0.8 \\
Other reasons & 2.8 & 5.2 & 1.5 \\
\hline
\end{tabular}

Source. World Bank calculations using the ENCOVI 2000, Instituto Nacional de Estadistica - Guatemala

${ }^{58}$ Pebley and Hurtado (1993) 
Table 3.14b: Reasons for Not Seeking Treatment by Consumption Quintile

\begin{tabular}{l|cccccc}
\hline $\begin{array}{l}\text { Percentage of Those Who Were III } \\
\text { but did not Seek Treatment }\end{array}$ & Total & Q1 & Q2 & Q3 & Q4 & Q5 \\
\hline Not important & 51.1 & 36.1 & 40.7 & 43.9 & 63.3 & 72.7 \\
Did not have time & 3.6 & 3.6 & 3.3 & 3.5 & 3.0 & 4.4 \\
Health facility too far & 6.2 & 12.2 & 8.5 & 6.7 & 2.0 & 1.1 \\
Not enough money for transport & 2.8 & 3.8 & 2.1 & 2.4 & 3.9 & 1.5 \\
Not enough money for visit & 26.4 & 32.4 & 33.1 & 33.0 & 21.1 & 12.4 \\
Service too expensive & 2.8 & 4.1 & 4.4 & 3.5 & 0.9 & 1.0 \\
Lack of transportation & 0.4 & 0.6 & 0.8 & 0.3 & 0.2 & 0.2 \\
Don't trust the person & 1.1 & 0.7 & 1.4 & 1.4 & 0.8 & 1.2 \\
Lack of doctors/nurses & 1.6 & 2.4 & 2.4 & 1.6 & 1.2 & 0.3 \\
Don't speak my language & 0.5 & 1.6 & 0.5 & 0.2 & 0.2 & 0.0 \\
Waiting time too long & 0.7 & 0.8 & 1.2 & 0.7 & 0.2 & 0.5 \\
Other reasons & 2.8 & 1.6 & 1.7 & 2.7 & 3.3 & 4.8 \\
\hline
\end{tabular}

Source World Bank calculations using the ENCOVI 2000, Instituto Nacional de Estadistica - Guatemala

Table 3.14c: Reasons for Not Seeking Treatment by Ethnicity

\begin{tabular}{l|ccc}
\hline $\begin{array}{l}\text { Percentage of Those Who Were Ill } \\
\text { but did not Seek Treatment }\end{array}$ & Total & Indigenous & Non-Indigenous \\
\hline Not important & 51.1 & 43.5 & 58.1 \\
Did not have time & 3.6 & 4.1 & 3.1 \\
Health facility too far & 6.2 & 8.8 & 4.0 \\
Not enough money for transport & 2.8 & 3.6 & 2.1 \\
Not enough money for visit & 26.4 & 28.6 & 24.2 \\
Service too expensive & 2.8 & 3.8 & 2.0 \\
Lack of transportation & 0.4 & 0.5 & 0.3 \\
Don't trust the person & 1.1 & 0.6 & 1.4 \\
Lack of doctors/nurses & 1.6 & 2.2 & 1.1 \\
Don't speak my language & 0.5 & 1.2 & 0.0 \\
Waiting time too long & 0.7 & 0.8 & 0.5 \\
Other reasors & 2.8 & 2.2 & 3.3 \\
\hline
\end{tabular}

Source World Bank calculations using the ENCOVI 2000, Instituto Nacional de Estadística - Guatemala

Another reason why Guatemalan people often do not seek "formal" health treatment is the widespread practice of traditional medicine. Although modern medicine is becoming increasingly dominant, traditional beliefs about sickness and health continue to inform rural Guatemalans' health ideas and choices. For example, as in other rural areas of Latin America, the indigenous people believe illness is caused by an imbalance of hot and cold. Therefore, they believe that a treatment will only be effective if the prescribed medicines or food are of the opposite temperature to the disorder so that the hot-cold balance can be re-established. ${ }^{59}$ Many people use both traditional and modern medicine, which they perceive as being complementary rather than in conflict with one another. ${ }^{60}$ Recent findings suggest that, with respect to the treatment of children's illnesses, modern medicine is currently used more frequently than traditional remedies and healers. ${ }^{61}$

\footnotetext{
${ }^{59} \operatorname{Logan}(1973)$.

${ }^{60}$ Cosminsky and Scrumshaw (1980).

${ }^{61}$ Heuveline and Goldman (1998).
} 


\section{Quality and Access to Services}

Quality and access to services are important determinants of individuals' health outcomes. In Guatemala poor quality and limited access are often the main reason for the observed underutilization of services.

QPES. The Qualitative Poverty and Exclusion Study QPES, through a detailed analysis of 10 villages, highlights important factors related to access to health services that support and enrich our results from the household survey. In particular, in most of the villages, there are no health services, but the midwives and informants report that the costs of traveling to access services in other localities are often prohibitive. In one village, individuals reported that they rarely go to the doctor in the municipal capital because it is expensive and because it is difficult to get there due to the poor quality of their access road. In another village, people felt that they had experienced "discrimination" while being served or receiving medicines due to their indigenous ethnicity or their inability to speak Spanish. ${ }^{62}$

Waiting Times. Tables 3.15 and 3.16 present information on the average waiting time at different health facilities. Waiting times are longer in IGSS hospitals and public hospitals and are shorter in pharmacies and private facilities. Waiting times are longer in rural areas for public hospitals, IGSS hospitals, and private facilities, of which there are not very many in rural areas. In contrast, waiting times are longer in urban areas for health posts and health centers and community centers, which are more common in rural areas.

Table 3.15:Average Waiting Time by Health Facility

\begin{tabular}{l|ccccccc}
\hline $\begin{array}{l}\text { Average Waiting } \\
\text { Time (minutes) }\end{array}$ & $\begin{array}{c}\text { Public } \\
\text { Hospital }\end{array}$ & $\begin{array}{c}\text { IGSS } \\
\text { Hospital }\end{array}$ & $\begin{array}{c}\text { Private } \\
\text { Hospital or } \\
\text { Clinic }\end{array}$ & $\begin{array}{c}\text { Health Post } \\
\text { or Health }\end{array}$ & $\begin{array}{c}\text { Community } \\
\text { Center }\end{array}$ & Pharmacy & Other \\
\hline Total & 66 & 87 & 37 & 59 & 33 & 14 & 29 \\
Urban Areas & 69 & 83 & 36 & 84 & 41 & 17 & 49 \\
Rural Areas & 64 & 102 & 37 & 49 & 31 & 12 & 21 \\
\hline
\end{tabular}

Source: World Bank calculations using the ENCOVI 2000, Instituto Nacional de Estadistica - Guatemala

People in the lowest consumption quintiles (and poor people in general) experience the lowest waiting times for each visit, while households in the highest consumption quintiles tend to wait the longest. Similarly, indigenous people on average wait less than non-indigenous people. This is explained by the fact that the poorer and indigenous people tend to use less-crowded facilities (in other words, health centers, health posts, and community centers) more often than better-off individuals and the nonindigenous.

${ }^{62}$ QPES (2001). 


\section{Table 3.16: Average Waiting Time by Selected Household Characteristics (Minutes)}

\begin{tabular}{|c|c|}
\hline \multirow{2}{*}{$\begin{array}{l}\text { Total } \\
\text { Consumption Quintile }\end{array}$} & 46 \\
\hline & \\
\hline Q1 & 38 \\
\hline Q2 & 42 \\
\hline Q3 & 48 \\
\hline Q4 & 54 \\
\hline Q5 & 45 \\
\hline \multicolumn{2}{|l|}{ Poverty Status } \\
\hline Non Poor & 48 \\
\hline All Poor & 44 \\
\hline Extremely Poor & 40 \\
\hline \multicolumn{2}{|l|}{ Ethnicity } \\
\hline Indigenous & 43 \\
\hline K'iche & 41 \\
\hline Q'ueqchi & 33 \\
\hline Kaqchiquel & 51 \\
\hline Mam & 39 \\
\hline Other Mayan & 51 \\
\hline Other Indigenous & 50 \\
\hline Non-indigenous & 48 \\
\hline \multicolumn{2}{|l|}{ Area } \\
\hline Urban & 51 \\
\hline Rural & 42 \\
\hline \multicolumn{2}{|l|}{ Region } \\
\hline Metropolitana & 55 \\
\hline Norte & 47 \\
\hline Nororiente & 37 \\
\hline Suroriente & 50 \\
\hline Central & 52 \\
\hline Suroccidente & 41 \\
\hline Noroccidente & 32 \\
\hline Peten & 40 \\
\hline
\end{tabular}

Source: World Bank calculations using the ENCOVI 2000, Instituto Nacional de Estadistica - Guatemala

Traveling Times. On average, children have to travel for about an hour to reach public hospitals. In practice, this means up to 75 minutes if they come from rural areas and only half that time if they are from urban areas. Community centers are the health facilities closest to Guatemalan children in rural areas, while health centers, health posts, and pharmacies are the closest to children in urban areas.

Table 3.17:Average Traveling Time by Type of Health Facility (Minutes)

\begin{tabular}{|c|c|c|c|c|c|c|c|c|}
\hline & $\begin{array}{l}\text { Public } \\
\text { Hospital }\end{array}$ & $\begin{array}{c}\text { IGSS } \\
\text { Hospital }\end{array}$ & $\begin{array}{c}\text { Private } \\
\text { Hospital or } \\
\text { Clinic }\end{array}$ & $\begin{array}{l}\text { Health Post } \\
\text { or Health } \\
\text { Center }\end{array}$ & $\begin{array}{l}\text { Community } \\
\text { Center }\end{array}$ & Pharmacy & Other & $\begin{array}{c}\text { Total } \\
\text { (Average) }\end{array}$ \\
\hline Total & 58 & 50 & 49 & 38 & 21 & 50 & 20 & 41 \\
\hline Urban Areas & 33 & 45 & 43 & 26 & 32 & 22 & 11 & 35 \\
\hline Rural Areas & 76 & 67 & 55 & 42 & 20 & 63 & 24 & 45 \\
\hline
\end{tabular}

Source: World Bank calculations using the ENCOVI 2000, Instituto Nacional de Estadistica - Guatemala 
Adequate access to health facilities is defined by the World Health Organization (WHO) as living no more than one hour of traveling time of a health care facility. Using this standard, only 41 percent of all children in Guatemala have access to health facilities. Access is more limited for children in rural areas (only 36 percent) than for children in urban areas ( 52 percent). Similarly, more than half of the children in the highest consumption quintile (58 percent) have access to health centers as opposed to a much lower proportion of children in the bottom quintiles (34 percent). Non-poor children have more access to health care facilities ( 48 percent) than do extremely poor children ( 34 percent) There is no large difference in access by ethnic group.

Table 3.18: Access to Health Facilities of Children affected by Diarrhea or Respiratory Infections - Proportion of Children with Access to the Health Facility

\begin{tabular}{l|c}
\hline & Traveling Time less than 60 Minutes \\
\hline Total & 40.8 \\
Consumption Quintile & \\
Q1 & 34.4 \\
Q2 & 40.5 \\
Q3 & 37.7 \\
Q4 & 44.3 \\
Q5 & 57.5 \\
Poverty Status & \\
Non Poor & 48.1 \\
All Poor & 37.2 \\
Extremely Poor & 33.6 \\
Ethnicity & \\
Indigenous & 38.3 \\
K'iche & 47.0 \\
Q'ueqchi & 34.4 \\
Kaqchiquel & 42.1 \\
Mam & 29.0 \\
Other Mayan & 38.5 \\
Other Indigenous & 63.1 \\
Non-indigenous & 43.1 \\
Area & \\
Urban & 51.7 \\
Rural & 36.3 \\
Region & \\
Metropolitana & 51.1 \\
Norte & 34.9 \\
Nororiente & 43.4 \\
Suroriente & 38.1 \\
Central & 36.7 \\
Suroccidente & 39.4 \\
Noroccidente & 40.0 \\
Peten & 36.1 \\
\hline Source: World Bank calculations using the ENCOV 2000, Instituto Nacional de Estadistica-Guatemala \\
\end{tabular}

Table 3.19 presents average travel time to different health centers for the Guatemalan population for the whole population. Results reflect a pattern similar to that observed for children. Hospitals appear to be the least accessible health facilities, especially for individuals living in rural areas who need about an hour and a half to get to one. 
Table 3.19: Average Traveling Time by Type of Health Facility (Minutes)

\begin{tabular}{l|cccccccc}
\hline & $\begin{array}{c}\text { Public } \\
\text { Hospital }\end{array}$ & $\begin{array}{c}\text { IGSS } \\
\text { Hospital }\end{array}$ & $\begin{array}{c}\text { Private } \\
\text { Hospital or } \\
\text { Clinic }\end{array}$ & $\begin{array}{c}\text { Health Post } \\
\text { or Health } \\
\text { Center }\end{array}$ & $\begin{array}{c}\text { Communit } \\
\text { y Center }\end{array}$ & Pharmacy & Other & Total \\
\hline Total & 63 & 51 & 47 & 41 & 25 & 38 & 25 & 45 \\
Urban Áreas & 42 & 50 & 36 & 26 & 28 & 17 & 29 & 35 \\
Rural Areas & 80 & 56 & 64 & 47 & 24 & 49 & 24 & 54 \\
\hline
\end{tabular}

Source: World Bank calculations using the ENCOVI 2000, Instituto Nacional de Estadística - Guatemala

Table 3.20 applies the definition of "access" to health facilities to the Guatemalan population and shows results disaggregated by selected characteristics. Only 11 percent of the total population who use health facilities live within one hour of the facility. The proportion is higher for people living in urban areas and in the highest consumption quintiles, while it is lower than 10 percent for individuals in the lower quintiles and for people living in rural areas. Almost 9 percent of indigenous people have access to health facilities as opposed to 12 percent of non-indigenous people.

By comparing Table 3.20 with Table 3.18, access to health facilities would seem to be much lower for adults than for children. The results seem puzzling, as the children in the survey come from the same families as the adults. A possible reason may lie in the different use of health facilities: as observed in Table 3.3 and Table 3.1, adults tend to use doctors or health-trained personnel more frequently than children, who instead rely on treatment by their father or other members of the household. Child morbidity may, therefore, be considered as less serious than that of adults. Thus, if the family would have to travel a long distance to take the child to the closest health center, this may dissuade the parents from taking their children to see a doctor. As a result, the children who are actually treated in a health facility may tend to live closer to health facilities. 
Table 3.20: Access to Health Facilities

Proportion of Adults with Access to the Health Facility

\begin{tabular}{l|c}
\hline & Traveling Time less than 60 Minutes \\
\hline Total & 10.7 \\
Consumption Quintile & \\
Q1 & 5.3 \\
Q2 & 7.0 \\
Q3 & 10.2 \\
Q4 & 11.8 \\
Q5 & 19.2 \\
Poverty Status & \\
Non Poor & 15.3 \\
All Poor & 7.1 \\
Extremely Poor & 5.2 \\
Ethnicity & \\
Indigenous & 8.7 \\
K'iche & 11.7 \\
Q'ueqchi & 9.2 \\
Kaqchiquel & 8.4 \\
Mam & 6.4 \\
Other Mayan & 6.9 \\
Other Indigenous & 16.3 \\
Non-indigenous & 12.2 \\
Area & \\
Urban & 14.4 \\
Rural & 8.3 \\
Region & \\
Metropolitana & 14.5 \\
Norte & 8.4 \\
Nororiente & 12.3 \\
Suroriente & 9.7 \\
Central & 10.5 \\
Suroccidente & 9.7 \\
Noroccidente & 7.8 \\
Peten & 8.8 \\
\hline Sewre World &
\end{tabular}

Source. World Bank calculations using the ENCOVT 2000, Instituto Nacional de Estadistica-Guatemala

\section{IV: Discussion}

Guatemala's poor health indicators are due, in part, to problems that are outside of the control of public health authorities and not likely to be solved in the short run. These problems include: (i) widespread poverty due to limited household resource availability; (ii) poor environmental conditions; (iii) the limited availability of private sector providers of an adequate quality; and (iv) a general lack of knowledge about the benefits of modern medicine, especially among the indigenous population. Changing these underlying factors will require effective economic programs to combat poverty (focused mostly on those rural areas with a large indigenous population) and expanded educational investments. 
Nevertheless, there are some actions that the government can and should take in the short- and mediumturn to improve health indicators and reduce inequality among areas and socioeconomic groups.

The relative youth of the Guatemalan population means that, for the foreseeable future, the major problems confronting the health sector will be those of the young instead of the old. The widespread poverty in the country means that the government's short-term priorities should be to combat the infectious and parasitic diseases associated with poverty, which are still more prevalent than noncommunicable diseases. Increasing knowledge and access to effective family planning methods, especially in rural areas and among the poor and the indigenous population, would both reduce population growth and improve reproductive and child health indicators. Given the limited resources currently assigned to health, the government should ensure that the planned increase in resources to the health sector does indeed materialize. The program to extend coverage of basic health services should be evaluated carefully, and the program should either be scaled-up or redesigned depending on the results of that evaluation. The frequency of blood transfusion as a cause of AIDS infection makes it essential to reform the national system of blood control.

In the medium-term, the government should attempt to mobilize additional resources for health and should take additional steps to improve the efficiency and quality of services offered. Some ways to do this include: (i) introducing a system of referral and counter-referral; (ii) charging IGGS beneficiaries for services that they receive in MSPAS facilities; (iii) allowing non-IGGS population to use IGGS facilities and charging the client, rather than MSPAS, for the use; and (iv) considering contracting out certain services within IGGS and MSPAS to private services (in addition to those contracted to NGOs to expand coverage of basic health care). As the population ages and the epidemiological transition progresses, more resources should be allocated to attempts to cure and prevent non-communicable and degenerative diseases.

In addition, two policy options are available to make public spending more progressive. The first is to move public resources away from hospitals towards community centers, health posts, and health centers (in other words, increasing the share of resources devoted to primary health care). The second is to introduce cost recovery mechanisms that charge different fees according to each user's income. The current policy of providing services free-of-charge in all type of public facilities benefits the rich more the poor, who tend to attend community centers, health posts, and health centers where- visits cost less in terms of both time and money. Increasing the total amount of resources invested in the health sector is a key recommendation because, in this way, more can be spent on preventive and primary care to improve basic services without having to reduce the absolute amount of resources available to hospitals. 


\section{References}

Amnesty International, 1998, Guatemala: All the Truth, Justice for All, AMR 34/02/98; also on the web at: http://www.web.amnesty.org/ai.nsf/index/AMR340021998.

Chen, L.C. and N.S. Scrimshaw (eds). 1983. Diarrhea and Malnutrition. Interactions, Mechanisms, and Interventions. New York: Plenum Press.

CIEN, 2000, El Proceso de Modernizacion de la Salud: Acciones Realizadas y Agenda Pendiente en Descentralizacion.

Clert, C., M. Woolcock, A., Ibañez and K. Lindert. 2001. A Social Exclusion Perspective to Poverty and Empowerment in Guatemala,: Key Quantitave and Qualitative Findings, Background Paper for the GUAPA, the World Bank.

Cosminsky, S. and M. Scrimshaw. 1980. Medical Pluralism on a Guatemalan Plantation. Soc. Sci.. \& Med. 148:267-278.

Deaton, A. 1997. The Analysis of Household Surveys: A Microeconometric Approach to Development Policy, The World Bank.

Demery L. 1997. Benefit Incidence Analysis, Poverty Reduction and Economic Management Network, The World Bank (unprocessed mimeo).

Edwards, J. 2001. Education and Poverty, Background Paper for the GUAPA, the World Bank.

Encuesta National de Salud Materno Infantil, 1995.

Encuesta National de Salud Materno Infantil, 1998-99.

GESTA consultants, 2001, Data Collection for Health and Poverty in Guatemala.

Gobierno de la Republica de Guatemala, Ministerio de Finanzas Publicas, 2001, Presupuesto General de Ingreso y Egresos del Estado, Guatemala, Enero 2001.

Heuveline, P. and N. Goldman. 1998. A Description of Child Illness and Treatment Behavior in Guatemala. Mimeo (Office of Population Research, Princeton University, NJ).

IDC. Revisión del Programa de Inversión Publica de Mediano Plazo. 1998. Guatemala, Nov. 1998

La Forgia G.M., I. Nieves and J. Ribera, 2000, Large Scale Government Contracting of NGOs to Extend Basic Health Services to Poor Population in Guatemala, in M. Rosenmöller, Challenges of Health Reform, the World Bank, IADB, Caja Costaricense de Seguro Social, IESE.

Logan, M.H. 1973. Human Medicine in Guatemala and Peasant Acceptance of Modern Medicine. Human Organization 32(4):385-395. 
Marini A. and M. Gragnolati, 2001, Nutrition and Poverty in Guatemala, Background Paper for the GUAPA, the World Bank.

Martorell, R. and C. Yarbrough. 1983. The Energy Cost of Diarrheal Diseases and Other Common Diseases in Children. Pp. 125-141 in Diarrhea and Malnutrition. Interactions, Mechanisms, and Interventions, eds L.C. Chen and N.S. Scrimshaw. New York: Plenum Press.

MSPAS, IGSS and OPS, 1998, Caracterización Del Fenómeno Laboral Migratorio en Guatemala, Guatemala.

MSPAS, OPS/OMS, 2001, Propuesta: Establecimiento de la Redes Sociales Locales, su Epidemiología Cultural, Recursos Etnoterapeuticos, su Interacción con el Medio Social y las redes del Sistema Oficial de Salud, Guatemala, Junio 2001.

Nieves, I. and G. La Forgia, 2000, Guatemala: Large Scale Government Contracting of NGOs to Extend Basic Health Services to Poor Populations in Guatemala, in M. Rosenmoller, Challenges of Health Reform, World Bank, IADB, Caja Costarricense se Seguro Social, IESE.

Núñez, César Antonio, 2001. Exclusión social y VIH-SIDA en Guatemala/ César Antonio Núñez, Víctor Hugo Fernández y Sergio Aguilar. Guatemala: Sistema de Nacion Unidas, 2001.

OPS/OMS, 2001, La Medicina Populares Tradicional y Su Articulacion a las Redes del Sistema Oficial de Salud. Segundo Informe.

PAHO, 1998, Health in the Americas. Volume I.

PAHO, 1998, Health Situation in the Americas, Basic Indicators.

PAHO, 1999, Guatemala: Profile of the Health Service System.

Pebley, A.R., E. Hurtado and N. Goldman, 1997, Beliefs about Children's Illness Among Rural Guatemalan Women. Journal of Biosocial Sciences.

Pebley, A.R. and P.W. Stupp. 1987. Reproductive Patterns and Child Mortality in Guatemala, Demography 24(1): 43-60.

COWI Consultants/World Bank. 2001. Qualitative Poverty and Exclusion Study.

Rohde, J.E. 1986. Acute Diarrhea. In Strategies for Primary Health Care: Technologies Appropriate for the Control of Disease in the Developing World, Eds. J.A. Walsh and K.S. Warren. Chicago: University of Chicago Press.

Selden T.M. and M. Wasylenko. 1992. Benefit Incidence Analysis in Developing Countries, World Bank Working Paper 1015, The World Bank.

Scrimshaw, N.S. and C. Tejada. 1970. In Handbook of Middle American Indians, Vol. 9, ed. T. Dale Stewart. Austin: University of Texas Press.

Torres, J.E. 2001. Infant Mortality and Morbidity from Exposure to Indoor Air Pollution in Guatemala, Evidence from the 1998-1999 DHS Survey, Consulting Report to the World Bank, August 2001.

UNICEF, 1999, The State of the World Children. 
U.S. Bureau of the Census, 1999. Report WP/98, World Population Profile: 1998, U.S. Government Printing Office, Washington D.C.

United Nations, 2001. World Population Prospects, The 2000 Revision Highlights, Population Division, United Nations, NY.

Victora, C.V., P. Vaughan, B.R. Kirkwood, J.C. Martines, and L.B. Barcelos, 1986. Risk Factors for Malnutrition in Brazilian Children: the Role of Social and Environmental Variables. Bulletin of the World Health Organization 64(2):299-309.

Victora, C.V., F.C. Barros, B.R. Kirkwood, and J.P. Vaughan. 1990. Pneumonia, Diarrhea, and Growth in the First 4 Years of Life. Am. .J Clin. Nutr. 52:391-396.

Wagstaff, A., 2000. An Introduction to Benefit Incidence Analysis in the Health Sector, The World Bank Washington D.C..

World Bank, 2001, World Development Indicators, The World Bank, Washington D.C..

World Bank, 2000, Guatemala: Expenditure Reform in a Post-Conflict Country, Central American Department, Latin America and the Caribbean Region, The World Bank, Washington D.C.. 


Policy Research Working Paper Series

Title

WPS2938 Recurrent Expenditure Requirements of Capıtal Projects. Estımation for Budget Purposes

WPS2939 School Attendance and Child Labor in Ecuador

WPS2940 The Potentıal Demand for an HIV/ AIDS Vaccine in Brazil

WPS2941 Income Convergence during the Disıntegration of the World Economy, 1919-39

WPS2942 Why is Son Preference so Persistent in East and South Asia? A CrossCountry Study of Chına, India, and the Republic of Korea

WPS2943 Capıtal Flows, Country Risk, and Contagion

WPS2944 Regulation, Productivity, and Growth OECD Evidence

WPS2945 Micro-FInance and Poverty Evidence Usıng Panel Data from Bangladesh

WPS2946 Rapid Labor Reallocation with a Stagnant Unemployment Pool The Puzzle of the Labor Market in Lithuanıa

WPS2947 Tax Systems in Transition

WPS2948 The Impact of Contractual Savings Institutions on Securities Markets

WPS2949 Intersectoral Migration in Southeast Asia Evidence from Indonesia, Thasland, and the Philıppınes

WPS2950 Is the Emerging Nonfarm Market Economy the Route Out of Poverty in Vietnam?

WPS2951 Land Allocation in Vietnam's Agrarian Transition
Author

Ron Hood

David Husband

Fel Yu

Gladys López-Acevedo

Hillegonda Marıa Dutılh

Novaes

Expedito J. A. Luna

Moısés Goldbaum

Samuel Kilsztajn

Anaclaudia Rossbach

José de la Rocha Carvalheıro

Branko Milanovic

Monica Das Gupta

Jiang Zhenghua

LI Bohua

Xie Zhenmıng

Woojın Chung

Bae Hwa-Ok

Norbert Fiess

Gluseppe Nicolett।

Stefano Scarpetta

Shahıdur R Khandker

Jan Rutkowskı

Pradeep Mitra

Nicholas Stern

Gregorio Impavido

Alberto R Musalem

Thierry Tressel

Rita Butzer

Yair Mundlak

Donald F Larson

Domınıque van de Walle

Dorothyjean Cratty

Martın Ravallıon

Domınıque van de Walle
Date

January 2003

$P$ Sader

33902

January 2003

January 2003

January 2003

January 2003

January 2003

Contact

for paper

M Galatıs

31177

M Geller 85155

$\mathrm{H}$ Sladovich 37698

M Das Gupta 31983

R Izquierdo 84161

Social Protection Advisory Service 85267

$\begin{array}{ll}\text { January 2003 } & \begin{array}{l}\text { D Afzal } \\ 36337\end{array} \\ \text { January 2003 } & \begin{array}{l}\text { J Rutkowskı } \\ 84569\end{array} \\ & \\ \text { January 2003 } & \text { S. Tassew } \\ & 88212 \\ \text { January 2003 } & \text { P Braxton } \\ & 32720 \\ & \\ \text { January 2003 } & \begin{array}{l}\text { P Kokıla } \\ 33716\end{array} \\ & \\ \text { January 2003 } & \text { H Sladovich } \\ & 37698 \\ & \\ \text { January 2003 } & \text { H Sladovich } \\ & 37698\end{array}$

D Afzal

J Rutkowskı 84569 37698 
Policy Research Working Paper Series

Title

WPS2952 The Effects of a Fee-Waiver Program on Health Care Utilization among the Poor. Evidence from Armenia

WPS2953 Health Facility Surveys' An Introduction

WPS2954 Never Too Late to Get Together Again: Turning the Czech and Slovak Customs Union into a Stepping Stone to EU Integration

WPS2955 The Perversity of Preferences: The Generalized System of Preferences and Developing Country Trade Polıcies, 1976-2000

WPS2956 Survey Compliance and the Distribution of Income

WPS2957 Mexıco: In-Firm Trainıng for the Knowledge Economy

WPS2958 Globalızatıon and Workers in Developing Countries

WPS2959 Wage Differentıals and StatePrivate Sector Employment Choice in the Federal Republic of Yugoslavia

WPS2960 The Poverty/Environment Nexus in Cambodia and Lao People's Democratic Republic

WPS2961 Strategic Planning for Poverty Reduction in Vietnam: Progress and Challenges for Meetıng the Localized Millennuum Development Goals

WPS2962 High Consumption Volatility: The Impact of Natural Disasters?

WPS2963 Catastrophe Insurance Market in the Caribbean Region. Market Failures and Recommendations for Public Sector Interventions

WPS2964 Wages and Productivity in Mexican Manufacturıng

WPS2965 Informality Revisited
Author

Nazmul Chaudhury

Jeffrey Hammer

Edmundo Murrugarra

Magnus Lındelów Adam Wagstaff

Bartlomıej Kaminskı

Beata Smarzynska

Çaglar Özden

Erıc Reınhardt

Johan A Mistiaen

Martin Ravallion

Hong Tan

Gladys Lopez-Acevedo

Martın Rama

Mıchael M. Lokshın

Branko Jovanovic

Susmita Dasgupta

Uwe Deichmann

Craıg Meisner

David Wheeler

Rob Swinkels

Carrie Turk

Philippe Auffret

Philıppe Auffret

William F. Maloney
Date

January 2003

January 2003

January 2003

January 2003

January 2003

January 2003

January 2003

January 2003

January 2003

January 2003

January 2003

January 2003

January 2003

January 2003
M. Geller

85155

Contact

for paper

N. Chaudhury 84230

H. Sladovich 37698

P. Flewitt 32724

P Flewitt 32724

P. Sader 33902

H. Tan 33206

$\mathrm{H}$ Sladovich 37698

P. Sader 33902

Y. D'Souza 31449

N Lopez 88032

$\mathrm{K}$ Tomlınson 39763

$\mathrm{K}$ Tomlınson 39763

P. Soto 37892 